A METHODOLOGY TO DETERMINE BOTH THE TECHNICALLY

RECOVERABLE RESOURCE AND THE ECONOMICALLY RECOVERABLE

RESOURCE IN AN UNCONVENTIONAL GAS PLAY

\author{
A Thesis \\ by \\ HUSAMEDDIN SALEH A. ALMADANI
}

\begin{abstract}
Submitted to the Office of Graduate Studies of Texas A\&M University

in partial fulfillment of the requirements for the degree of

MASTER OF SCIENCE
\end{abstract}

August 2010

Major Subject: Petroleum Engineering 


\title{
A METHODOLOGY TO DETERMINE BOTH THE TECHNICALLY \\ RECOVERABLE RESOURCE AND THE ECONOMICALLY RECOVERABLE \\ RESOURCE IN AN UNCONVENTIONAL GAS PLAY
}

\author{
A Thesis \\ by \\ HUSAMEDDIN SALEH A. ALMADANI \\ Submitted to the Office of Graduate Studies of \\ Texas A\&M University \\ in partial fulfillment of the requirements for the degree of \\ MASTER OF SCIENCE
}

Approved by:

Chair of Committee, Stephen A. Holditch

Committee Members, Walter B. Ayers

Julian E. Gaspar

Head of Department, Stephen A. Holditch

August 2010

Major Subject: Petroleum Engineering 


\begin{abstract}
A Methodology to Determine both the Technically Recoverable Resource and the Economically Recoverable Resource in an Unconventional Gas Play.
\end{abstract}

(August 2010)

\author{
Husameddin Saleh A. AlMadani, B.S., University of Kansas \\ Chair of Advisory Committee: Dr. Stephen A. Holditch
}

During the past decade, the worldwide demand for energy has continued to increase at a rapid rate. Natural gas has emerged as a primary source of US energy. The technically recoverable natural gas resources in the United States have increased from approximately 1,400 trillion cubic feet (Tcf) to approximately 2,100 trillion cubic feet (Tcf) in 2010. The recent declines in gas prices have created short-term uncertainties and increased the risk of developing natural gas fields, rendering a substantial portion of this resource uneconomical at current gas prices.

This research quantifies the impact of changes in finding and development costs (F\&DC), lease operating expenses (LOE), and gas prices, in the estimation of the economically recoverable gas for unconventional plays. To develop our methodology, we have performed an extensive economic analysis using data from the Barnett Shale, as a representative case study. We have used the cumulative distribution function (CDF) of the values of the Estimated Ultimate Recovery (EUR) for all the wells in a given gas play, to determine the values of the P10 ( $10^{\text {th }}$ percentile $)$, P50 $\left(50^{\text {th }}\right.$ percentile $)$, and P90 
$\left(90^{\text {th }}\right.$ percentile) from the CDF. We then use these probability values to calculate the technically recoverable resource (TRR) for the play, and determine the economically recoverable resource (ERR) as a function of $\mathrm{F} \& \mathrm{DC}, \mathrm{LOE}$, and gas price. Our selected investment hurdle for a development project is a $20 \%$ rate of return and a payout of 5 years or less. Using our methodology, we have developed software to solve the problem. For the Barnett Shale data, at a F\&DC of $\$ 3$ Million, we have found that $90 \%$ of the Barnet shale gas is economically recoverable at a gas price of $\$ 46 / \mathrm{Mcf}, 50 \%$ of the Barnet shale gas is economically recoverable at a gas price of $\$ 9.2 / \mathrm{Mcf}$, and $10 \%$ of the Barnet shale gas is economically recoverable at a gas price of $\$ 5.2 / \mathrm{Mcf}$. The developed methodology and software can be used to analyze other unconventional gas plays to reduce short-term uncertainties and determine the values of F\&DC and gas prices that are required to recover economically a certain percentage of TRR. 


\section{DEDICATION}

To Dr. Ghazi AlQusaibi who has, unknowingly, inspired entire generations of positive citizens and change agents in Saudi Arabia throughout

his life commitment and long years of

dedicated public

service.

To the late Eng. Bandar AlAnazi, who, during his very short life

on earth, carried an inspiring passion

for engineering, knowledge sharing,

and community

service. 


\section{ACKNOWLEDGEMENTS}

This thesis would not have been possible without the guidance and support from my committee chair, Dr. Stephen Holditch, throughout the course of research. I am indebted to his distinctive knowledge and ability to challenge me while providing the essential supervision to ensure the fruition of this research. I would also like to thank $\mathrm{Mr}$. George Voneiff with Unconventional Gas Resources, LLC, and Mr. William D. Von Gonten, Jr. with WD Von Gonten \& Company for providing datasets and feedback to calibrate my research findings.

My sincere thanks also go to my advisory committee members, Dr. Walter B. Ayers and Dr. Julian E. Gaspar for their critical feedback, significant input, and mentorship during this journey. Their confidence in my ability to conduct this research has always inspired me to rise to the challenge.

I would also like to express my gratitude to my wife, Anat AlMadani, for her patience, love and support. She has always been there for me, and for that, I am most grateful.

Finally, I would like to express my sincere appreciation to Saudi ARAMCO, for sponsoring my graduate school and for providing its employees with unprecedented development resources to be the best employes and citizens they can be. I am truly proud to be associated with a company with unrivaled commitment to maintain its worldleading role as a reliable energy provider to the globe while developing and nurturing the future generations of engineers and leaders of Saudi Arabia. 


\section{NOMENCLATURE}

$\begin{array}{ll}\text { Bcf } & \text { billion cubic feet } \\ \text { CBM } & \text { coalbed methane } \\ \text { CDF } & \text { cumulative distribution function } \\ \text { DOE } & \text { Department of Energy } \\ \text { EIA } & \text { Energy Information Administration } \\ \text { ERR } & \text { economically recoverable resource } \\ \text { EUR } & \text { estimated ultimate recovery } \\ \text { F\&DC } & \text { finding and development cost } \\ \text { LOE } & \text { lease operating expenses } \\ \text { Pcf } & \text { million cubic feet } \\ \text { P50 } & \text { million cubic feet equivalent } \\ \text { Mcfe } & \text { original gas in place } \\ \text { OGIP } & \text { cumulative distribution function of EURs } \\ \text { P(EUR) } & \begin{array}{l}\text { a percentile } \\ \text { P10 }\end{array}\end{array}$

P50 Well

a well with a $50 \%$ chance of a higher EUR and a $50 \%$ chance of less EUR than the $50^{\text {th }}$ percentile 
P90 Well

P* Well

ROR

Tcf

TRR

UG

USGS

VBA a well with a $10 \%$ chance of EUR that is higher than the $90^{\text {th }}$

percentile

a well with a weighted EUR based on P10, P50, and P90 EUR

values

rate of return

trillion cubic feet

technically recoverable resource

unconventional gas

US Geological Survey

Visual Basic Application 


\section{TABLE OF CONTENTS}

Page

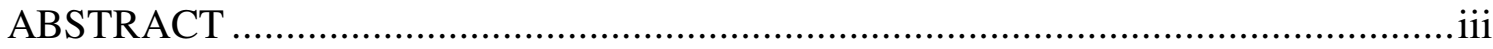

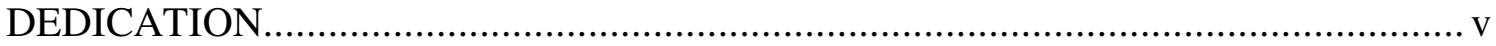

ACKNOWLEDGEMENTS .............................................................................. vi

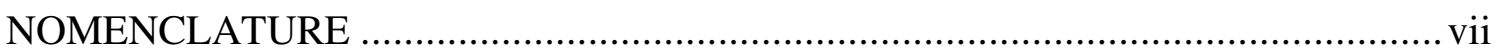

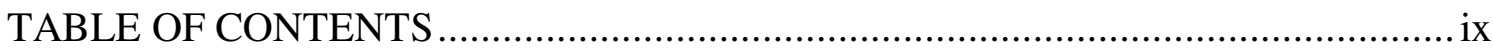

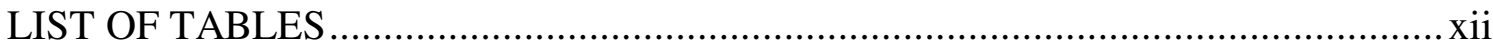

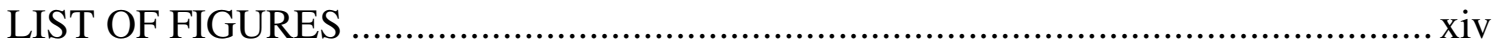

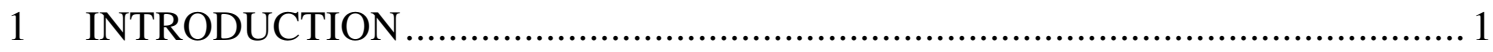

1.1 The Natural Gas Resource Base.................................................................... 4

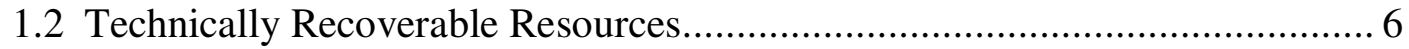

1.3 Economically Recoverable Resources ................................................ 7

1.4 Estimated Ultimate Recovery (EUR) ................................................... 8

1.5 Significance of Unconventional Gas Development .................................. 10

2 THE QUESTION AND OBJECTIVES ................................................ 13

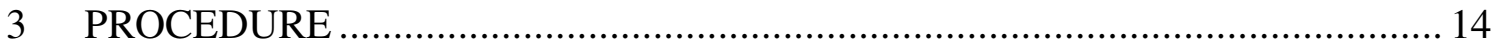

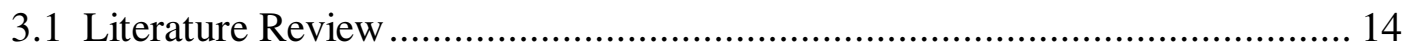

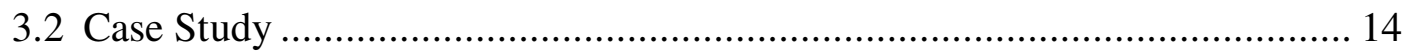

4 FACTORS AFFECTING THE ESTIMATION OF ECONOMICALLY

RECOVERABLE GAS RESOURCES …................................................... 15

4.1 Finding and Development Cost........................................................ 15 
4.2 Lease and Operating Expenses .......................................................... 16

4.3 Gas Prices ....................................................................................... 17

4.3.1 The Price Cycle .......................................................................... 18

4.3.2 The Effect of Weather .............................................................. 19

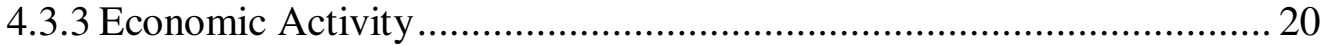

4.3.4 Underground Storage................................................................ 20

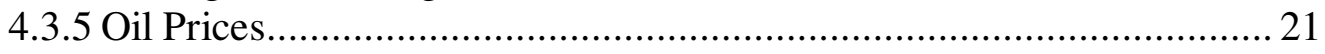

5 INVESTMENT HURDLE: WHAT IS ECONOMICAL?................................ 22

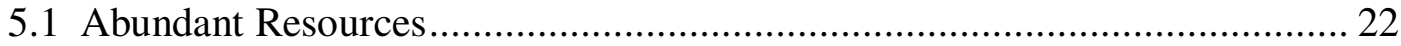

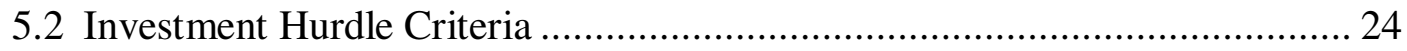

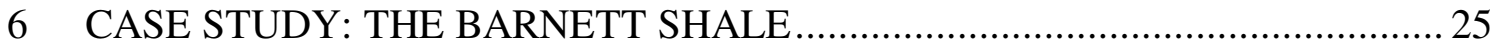

6.1 The Barnett Shale: A Hot Play ............................................................... 25

6.2 Barnett Shale Production Profile................................................................ 29

6.3 Production Forecast Using Hyperbolic Decline Curves............................... 30

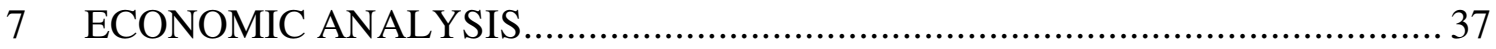

7.1 Well-Level Economics: Scenario I ...................................................... 37

7.1.1 Economics for P10, P50, P90 Wells at Scenario I ............................. 37

7.1.2 Economics forP* Well at Scenario I ............................................. 43

7.2 Well-Level Economics: Scenario II ............................................... 47

7.2.1 Economics for P10, P50, P90, and P* Wells at Scenario II................. 48

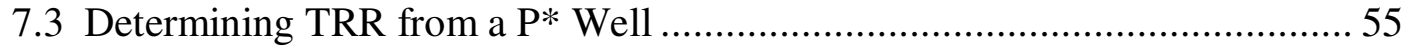

7.4 Sensitivity Analysis ................................................................................ 56

7.5 Economic Analysis at Every Percentile ........................................... 59

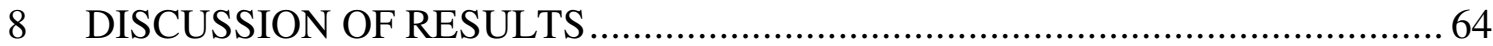

9 CONCLUSIONS AND RECOMMENDATIONS .......................................... 69

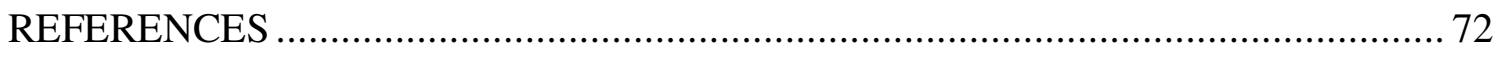

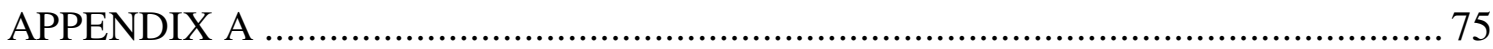




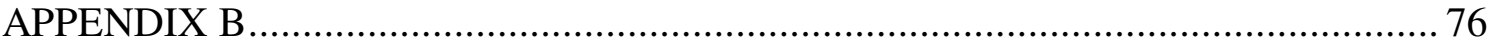

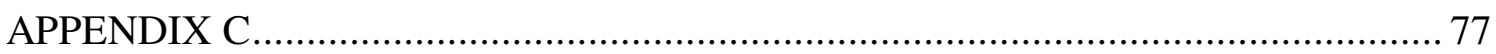

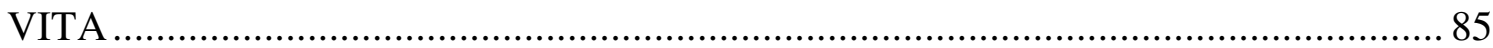




\section{LIST OF TABLES}

TABLE

1.1-Distributions of Worldwide Unconventional Gas Reservoirs. (After Kawata and Fujita 2001, and Rogner 1997) ..........................................5

5.1—TRR for United States Shale Gas Basins. (Navigant, 2008) ..................... 23

6.1—Barnett Shale Counties. (Texas Railroad Commission, 2010).................... 26

6.2-EUR Values for P10 Well, P50 Well, and P90 Well................................. 30

6.3-Input to the Hyperbolic Decline Curve for P10, P50, and P90 Wells........... 31

6.4-25-Year Production Profile before Scaling............................................ 34

6.5-25-Year Production Profile after Scaling to Produce All EUR................... 35

7.1-Gas Prices to Meet Investment Hurdle at Different F\&D Costs at

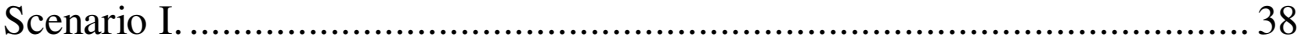

7.2 - Detailed Economic Analysis for a P10 Well with an F\&DC of \$2 Million

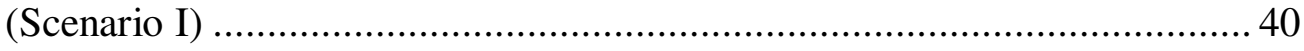

7.3-Detailed Economic Analysis for a P50 Well with an F\&DC of \$2 Million (Scenario I)

7.4 - Detailed Economic Analysis for a P90 Well with an F\&DC of \$2 Million (Scenario I)

7.5-Gas Prices to Meet Investment Hurdle at Different F\&DCs for a P10, P50, P90, and P* Well. (Scenario I).

7.6-Detailed Economic Analysis for a P*Well with an F\&DC of \$2 Million (Scenario I)

7.7—ROR and Payout Periods for P10, P50, P90, and P* with a $\$ 2$ Million F\&DC (Scenario I)

7.8 - Gas Prices to Meet the Investment Hurdle at Different F\&DCs for a P10, P50, P90, and P* Well (Scenario II) 
7.9-Detailed Economic Analysis for a P10 Well with an F\&DC of \$2 Million (Scenario II)

7.10 — Detailed Economic Analysis for a P50 Well with an F\&DC of \$2 Million (Scenario II).................................................................. 52

7.11 - Detailed Economic Analysis for a P90 Well with an F\&DC of \$2 Million (Scenario II). 53

7.12 - Detailed Economic Analysis for a P* Well with an F\&DC of \$2 Million (Scenario II)

7.13-ROR and Payout Periods for P10, P50, P90, and $\mathrm{P}^{*}$ with an F\&DC of $\$ 2$ Million (Scenario II)

7.14-Sensitivity Analysis for Barnett Shale Based on a P* Well.

7.15-Gas Price Required to Meet the Investment-Hurdle Criteria at Every Percentile for Different F\&D Costs. 59

8.1-ERR/TRR for the Barnett Shale at Different F\&D Costs and Gas Prices of $\$ 3, \$ 4, \$ 5$, and $\$ 10 / \mathrm{Mcf}$ 


\section{LIST OF FIGURES}

FIGURE

Page

1.1-Impact of Technology and Economic Conditions on Gas Recovery............. 3

1.2-Resource Triangle for Natural Gas. (Holditch, 2006)............................. 4

1.3 - Growth of US Technically Recoverable Natural Gas Resources. (EIA,

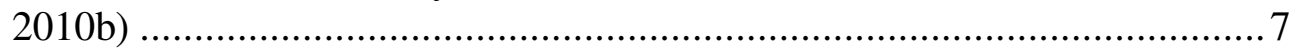

1.4-EIA Resource Classification and Organization. (EIA) .......................... 8

1.5-Oil, Gas, and Water Production Data from a Well in a an Unconventional Resource. (Cook, 2005) ............................................ 9

1.6-Example of an EUR distribution for 4000 Wells in an Unconventional Gas Resource. ................................................. 10

1.7-Forecast of Shale Gas Growth in Meeting Energy Demand. (EIA, 2010b)

1.8-Unconventional Natural Gas Outlook in the US (Bcf/day). (DOE, 2009)...12

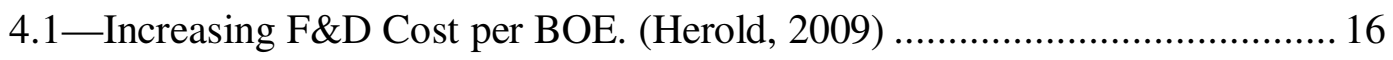

4.2-F\&D Cost Vary between Regions. (Herold, 2009).................................. 16

4.3-2006-2010 Monthly Natural Gas Prices - Based on Henry Hub. (CME,

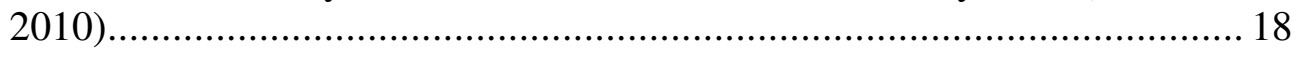

4.4_Projected Natural Gas Prices. (EIA, 2010b) ...................................... 19

4.5-Gas Prices Trail Oil Prices (EIA, 2010b) ........................................... 21

5.1—United States 25 North American Basins (Singh, 2006)......................... 22

5.2_United States Shale Gas Basins. (DOE, 2009) .................................... 23

6.1-Barnett Shale in the Fort Worth Basin.(DOE,2009) ...............................25

6.2-Barnett Shale Annual Total Gas Production. (Texas Railroad Commission, 2010) . 
6.3-Barnett Shale Well Count from 1993 through 2009. (Texas Railroad Commission, 2010)

6.4 -40-Year Production Forecast for P10, P50, and P90 Wells. 32

6.5-25-Year Production Forecast for P10, P50, P90 Wells. 33

6.6-25-Year Cumulative Production for P10, P50, and P90 Wells. 36

7.1—Gas Prices Required to Meet Investment Hurdle at Different F\&D Costs(Scenario I)

7.2-Confidence Intervals for a Normal Distribution Curve.

7.3-Gas Prices to Meet Investment Hurdle at Different F\&DCs a P10, P50, P90, and P* Well(Scenario I)

7.4-Gas Prices to Meet the Investment Hurdle at Different F\&D Costs a P10, P50, P90, and P* Well (Scenario II) 50

7.5-Sensitivity Analysis Chart for Barnett Shale Based on a P* Well. 58

7.6-Gas Prices To Meet the Investment-Hurdle for Each Percentile for Different F\&DC

8.1-Required Gas Prices for Different F\&DCs at Selected ERR/TRR 65

8.2-Percentage of ERR/TRR at Different Gas Prices and Different F\&DCs

8.3-Percentage of ERR/TRR at Different Gas Prices and Different F\&DCs on a Semi-Log Scale 


\section{INTRODUCTION}

With declining conventional gas reserves in the United States, unconventional gas reservoirs are emerging as critical energy sources to meet the ever increasing demand for energy. The US Department of Energy's April 2009 report, “Modern Shale Gas Development in the United States: A Primer," stated that over the last decade, production from unconventional resources in the US has increased almost 65\%, from 5.4 trillion cubic feet per year (Tcf/yr) in 1998 to $8.9 \mathrm{Tcf} / \mathrm{yr}$ in 2007. This increase in production indicates that approximately $46 \%$ of today's US total gas production comes from unconventional resources (Navigant 2008).

The increasing reliance on unconventional resources has captured the interest of the oil and gas industry in assessing the amount of unconventional gas that is technically recoverable in the US and worldwide. Today, the US Geological Survey, among other agencies, periodically assesses and provides ample information in terms of how much gas is technically recoverable in US basins. However, due to the nature of unconventional resources and the complexity of the analysis required to develop them, less emphasis has been placed on quantifying the impact of the range of factors that influence the calculation of how much gas is economically recoverable. Currently, with the publically available production data, gas prices, and costs for US basins, there is an opportunity to develop a methodology to estimate how much gas can be economically recovered from the reported assessments given a range of prices and costs.

This thesis follows the style of SPE Production and Facilities. 
An unconventional gas reservoir can be defined as a natural gas reservoir that cannot be produced at economic flow rates or in economic volumes unless the well is stimulated by a large hydraulic fracture treatment, a horizontal wellbore, or multilateral wellbores (Holditch, 2006). The three most common types of unconventional gas resources are tight sands, coalbed methane (CBM), and gas shales. Due to the very low permeability of unconventional gas reservoirs, the cost of finding, developing, and managing those resources are usually significantly higher than with conventional resources. For example, the number of wells, required to economically develop an unconventional resource is, in general, significantly higher than the number of wells required to develop a conventional reservoir. The need for drilling more wells translates into the need for higher investment and higher economic risk when it comes to the management of unconventional gas reservoirs.

Technology, finding and development cost (F\&DC), lease operating expenses (LOE), and market gas prices, play significant role in determining the amount of economically recoverable gas from the reservoir's original gas in place (OGIP). OGIP refers to the total volume of gas contained in a reservoir before production. Using current technology, and disregarding costs, prices, and other investment criteria, the proportion of OGIP that can be technically produced is called technically recoverable resources (TRR), which is always less than the OGIP. However, with favorable economic conditions and incentives, a portion of TRR can be economically produced and is referred to as economically recoverable resources (ERR). Fig. 1.1 illustrates the relationship between OGIP, TRR, and ERR. 


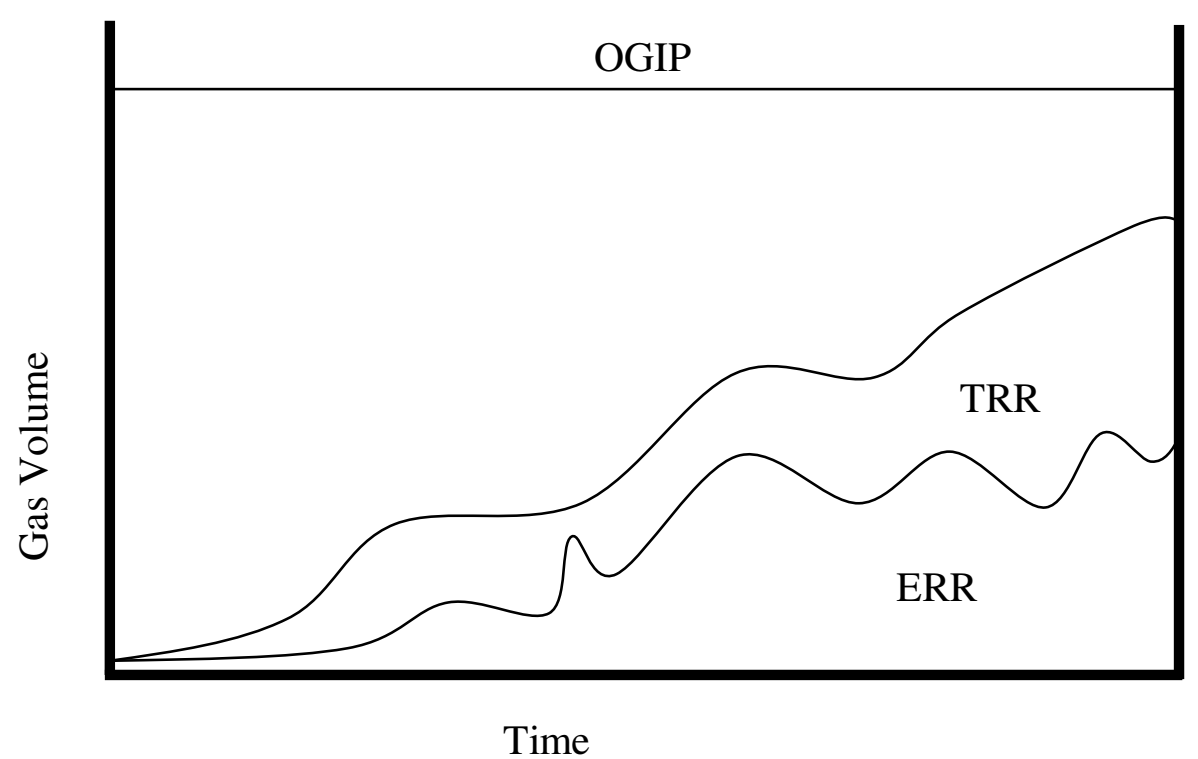

Fig. 1.1-Impact of Technology and Economic Conditions on Gas Recovery.

According to the EIA, the estimated TRR of natural gas in the US is more than 1,744 trillion cubic feet (Tcf) (EIA, 2007). Of this 1,744 Tcf, approximately $211 \mathrm{Tcf}$ is classified as ERR. The TRR of unconventional gas accounts for $60 \%$ of the onshore recoverable resource (Navigant, 2008).

The petroleum literature and other public databases contain estimates of OGIP and TRR for the different US basins. In accordance with government regulations, where SEC rules require publically traded oil and gas companies to report their proved reserves, many ERR estimates also exist for US basins. The values of resources included in SEC reports are computed specific gas prices, F\&DC, LOE, and specific investment criteria.

In this research, we will develop a methodology to quantify and correlate the variables that influence the calculation of ERR (mainly F\&DC, LOE, and gas prices), for unconventional gas reservoirs. We will use the methodology to estimate the ERR and 
TRR given a range of F\&DC, LOE, gas prices and specific investment criteria, using the Barnett Shale in the Fort Worth Basin as the primary data set.

\subsection{The Natural Gas Resource Base}

Gas reservoirs are classified as conventional or unconventional. Conventional gas reservoirs are characterized by high permeability with the gas stored in sands and carbonates formations in pore spaces that are interconnected. A gas resource is generally considered conventional if it is characterized by permeability in the millidarcy range or higher.

Unconventional gas reservoirs are characterized by low permeability with the gas stored in tight formations such as tight sands, coalbeds, and shale. A gas resource is generally considered unconventional if it is characterized by permeability in the microdarcy range (Fig. 1.2). As the permeability deceases, the economic risk of developing the resource increases, and the investment required also increases.

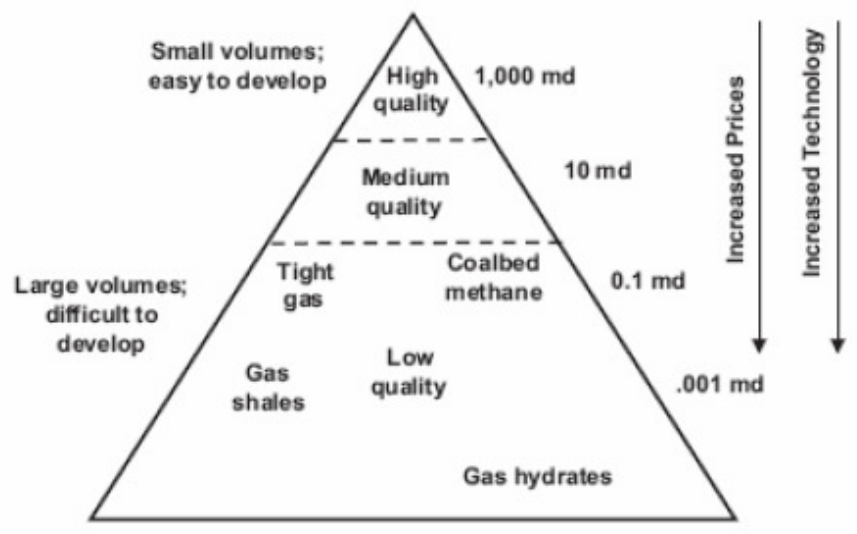

Fig. 1.2-Resource Triangle for Natural Gas. (Holditch, 2006) 
The EIA defines the total natural gas resource base as all of the gas that has ever been trapped inside the earth, including the volumes that have already been produced. The part of the total natural gas resource base that interests investors most, however, is the remaining natural gas waiting to be extracted. Research indicates the existence of large, unconventional gas reservoirs located throughout the world. Rogner (1997) estimates that there are 9,000 Tcf of OGIP in coalbed methane, 16,000 Tcf of OGIP in shale gas, and 7,400 Tcf of OGIP in tight gas sands around the world (Table 1.1).

Table 1.1—Distributions of Worldwide Unconventional Gas Reservoirs. (After Kawata and Fujita 2001, and Rogner 1997)

\begin{tabular}{|c|c|c|c|c|}
\hline Region & $\begin{array}{c}\text { Coalbed } \\
\text { Methane }\end{array}$ & Shale Gas & Tight-Sand Gas & Total \\
\hline North America & $($ Tcf $)$ & $($ Tcf $)$ & (Tcf) & (Tcf) \\
\hline Latin America & 3,017 & 3,842 & 1,371 & 8228 \\
\hline Western Europe & 39 & 2,117 & 1,293 & 3448 \\
\hline Central and Eastern Europe & 157 & 510 & 353 & 1019 \\
\hline Former Soviet Union & 118 & 39 & 78 & 235 \\
\hline Middle East and North Africa & 3,957 & 627 & 901 & 5485 \\
\hline Sub-Saharan Africa & 0 & 2,548 & 823 & 3370 \\
\hline Centrally planned Asia and China & 1,215 & 3,528 & 784 & 1097 \\
\hline $\begin{array}{c}\text { Pacific (Organization for } \\
\text { Economic Cooperation and }\end{array}$ & 470 & 2313 & 705 & 5094 \\
\hline Development) & 0 & 314 & 549 & 8,487 \\
\hline Other Asia Pacific & 39 & 0 & 196 & 235 \\
\hline South Asia & 9,051 & 16,112 & 7,406 & 32,560 \\
\hline World & & & & \\
\hline
\end{tabular}

Since Rogner published his paper, the oil and gas industry has discovered enormous volumes of natural gas in North American gas and in coalbed methane around 
the world. It is believed that the OGIP estimates in Table 1.1 are very conservative. The industry will be updating the values in Table 1.1 and it is expected that the values of OGIP will increase substantially. Once the new values are estimated, it will be important to estimate both TRR and ERR globally.

\subsection{Technically Recoverable Resources}

Recoverable resources are defined as the part of the total resource base that can be extracted from the earth with current technology. Typically, we locate reservoirs containing recoverable resources using seismic, geology, and drilling exploration wells. Once discovered, we can quantify the technically recoverable resource. For existing reservoirs, TRR includes all the gas that has been produced, is currently being produced, or has yet to be produced.

Undiscovered resources consist of deposits whose exact locations have not been identified, but whose existence seems likely because of geologic settings. Although geologists cannot specify an exact location for a reservoir's location, they can be reasonably certain that these natural gas reservoirs exist in specific basins and formations. In the US, the Department of the Interior (DOI) and the US Geological Survey (USGS 2005) estimate how much undiscovered recoverable natural gas there is either in the United States or in offshore areas that are under the government's control. The total discovered and undiscovered recoverable resources are called technically recoverable resources (TRR). They include resources that can be recovered even when recovery is not currently economically feasible. According to EIA (2010b), the recent 
growth of technically recoverable natural gas resources in the US is primarily because of growth in shale gas resources (Fig. 1.3).

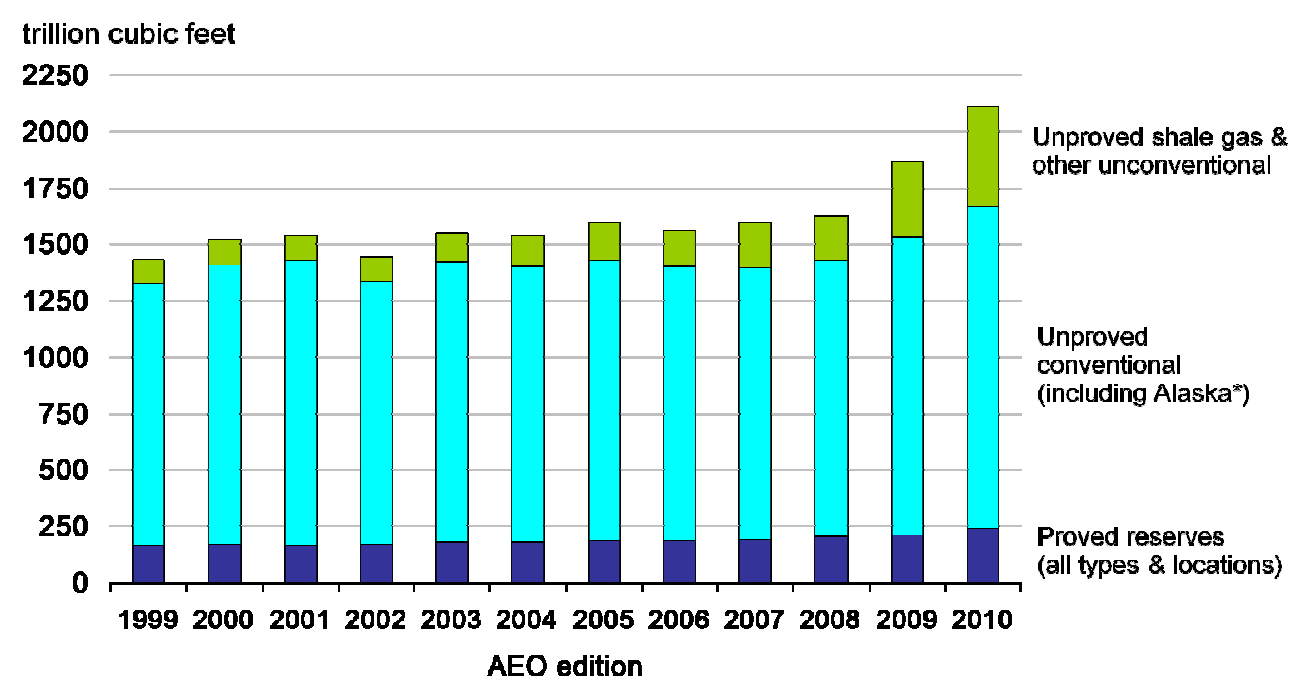

Fig. 1.3—Growth of US Technically Recoverable Natural Gas Resources. (EIA, 2010b)

\subsection{Economically Recoverable Resources}

Those resources that have been discovered, and for which a specific reservoir location is known, can further be broken down into those resources that are currently economically recoverable, and those that are not currently economically recoverable. Economically recoverable resources are natural gas resources where the extraction cost is low enough, or gas prices are high enough, for natural gas companies to make a profit. However, as illustrated in the resource triangle concept (Fig. 1.2), if either the gas price increases, or the technology improves, economically unrecoverable resources may become recoverable. This is a different category than that of technically unrecoverable resources, because although the technology either exists or will exist, it just costs too 
much, compared to market gas prices, for extraction to be profitable. Fig. 1.4 illustrates the different classifications of resources as presented by EIA.

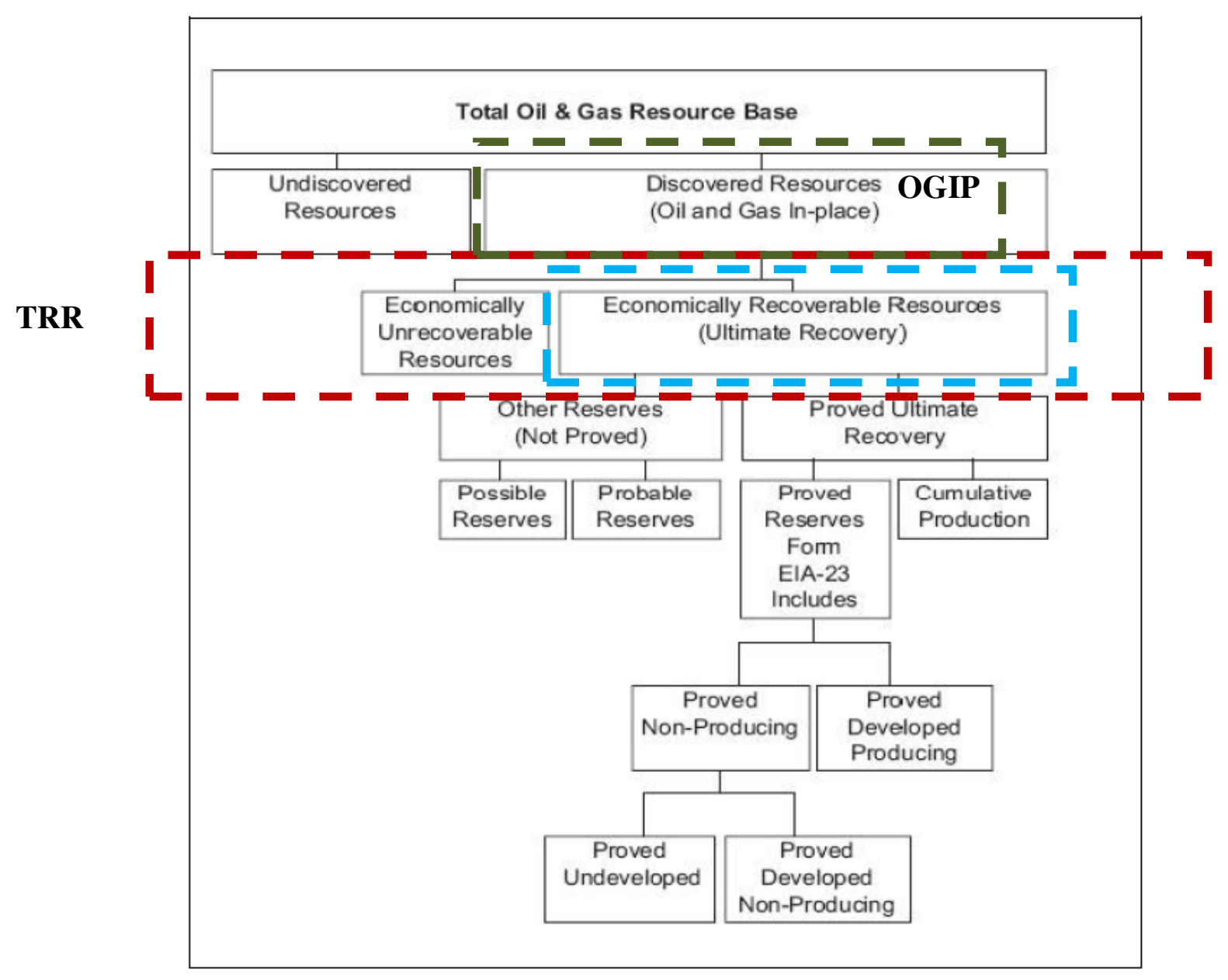

Fig. 1.4-EIA Resource Classification and Organization. (EIA)

\subsection{Estimated Ultimate Recovery (EUR)}

The Estimated Ultimate Recovery (EUR) refers to the quantities of petroleum which are estimated to be potentially recoverable from an accumulation, including those quantities that have already been produced.EUR can be calculated using different methods. The calculation of Estimated Ultimate Recovery (EUR) from oil and gas 
production data of individual wells and the development of EUR distributions from all producing wells in an assessment unit are important steps in the quantitative assessment of continuous-type hydrocarbon resources (Cook, 2005). Unconventional gas resources are considered continuous-type hydrocarbon resources. The method adopted by USGS 2005 is to calculate EURs for all wells that have produced in an unconventional gas resource area, define an EUR distribution for all EURs, then use the cumulative distribution function to estimate the EUR for potential wells in the same area.

The EUR for a producing well is calculated by analyzing its production rate for a specific timeframe. During the analysis, the production data are plotted against time, and a hyperbolic curve is fit through the data. The EUR is the sum of all gas that is expected to be produced up to end of the well's life (Fig.1.5).

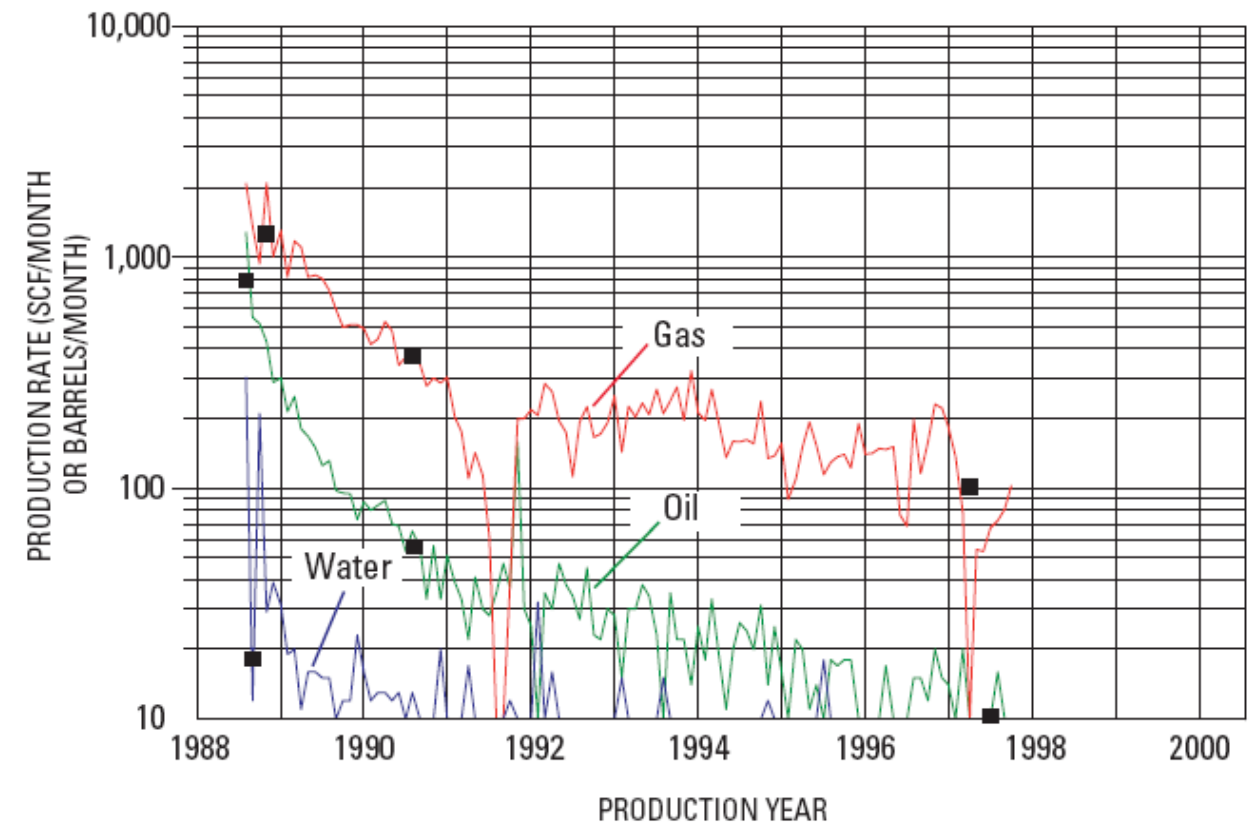

Fig.1.5-Oil, Gas, and Water Production Data from a Well in a an Unconventional Resource. (Cook, 2005) 
Using the calculated EURs for all producing wells, an EUR distribution is plotted on a semi-log graph with the EURs on the $x$-axis and the percentage of wells in the subset of producing wells on the $y$-axis (Fig. 1.6).

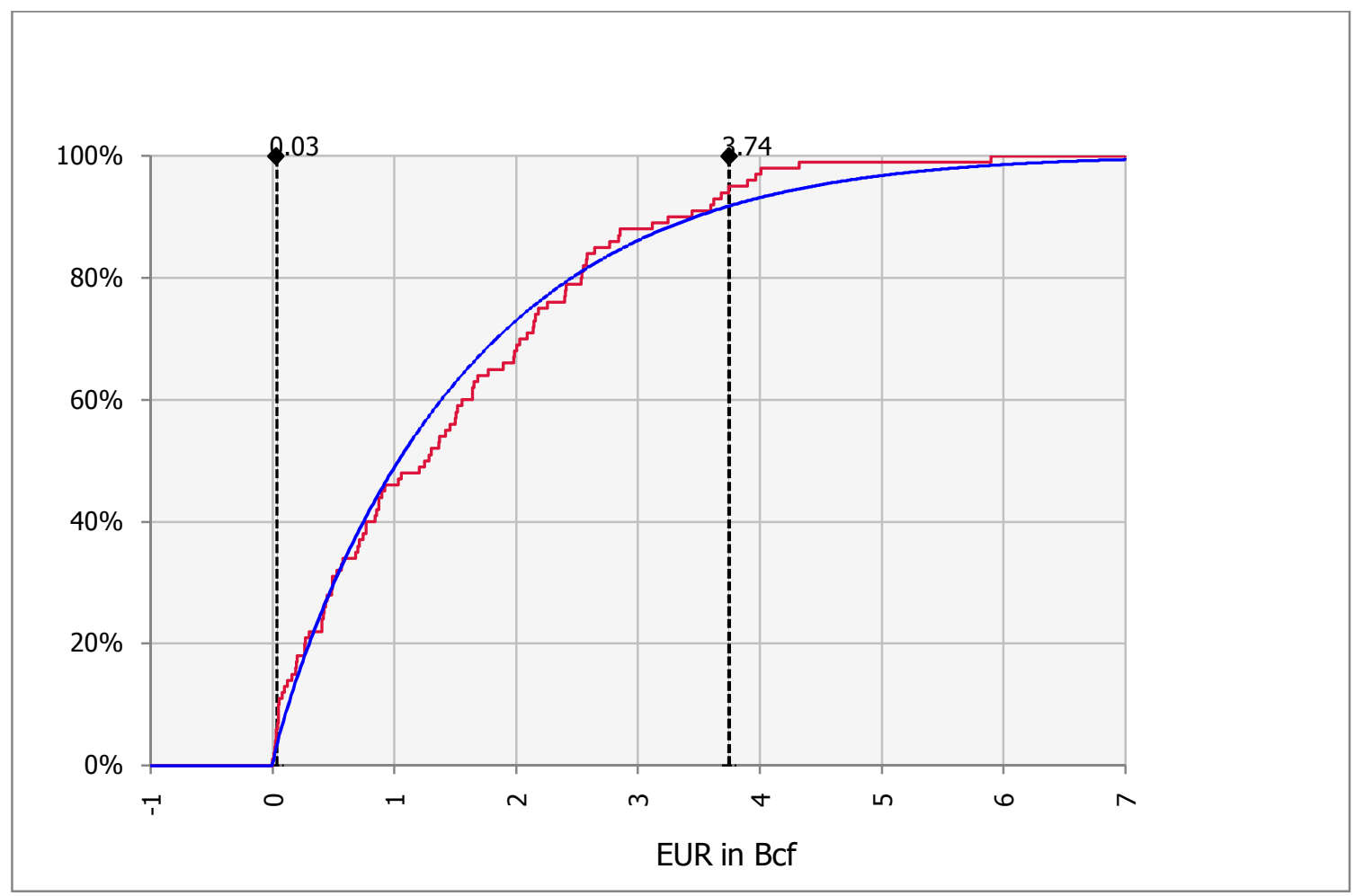

Fig. 1.6 Example of an EUR distribution for 4000 Wells in an Unconventional Gas

Resource.

\subsection{Significance of Unconventional Gas Development}

In the US, $85 \%$ of the energy used currently comes from coal, oil, or natural gas; $22 \%$ of the total energy comes from natural gas. Some experts think the percent contribution of natural gas to the US energy supply will be fairly constant over the next 20 years (EIA, 2007). It is also plausible that the volume of natural gas produced in the 
US could increase substantially in the coming decades. Natural gas from gas shales can be used to generate more electricity or provide for transportation fuel. It will continue to be a major contributor of energy within the US because it is both abundant and recoverable. Shale gas will continue offsetting the decline in energy supply to meet consumption growth (Fig. 1.7).

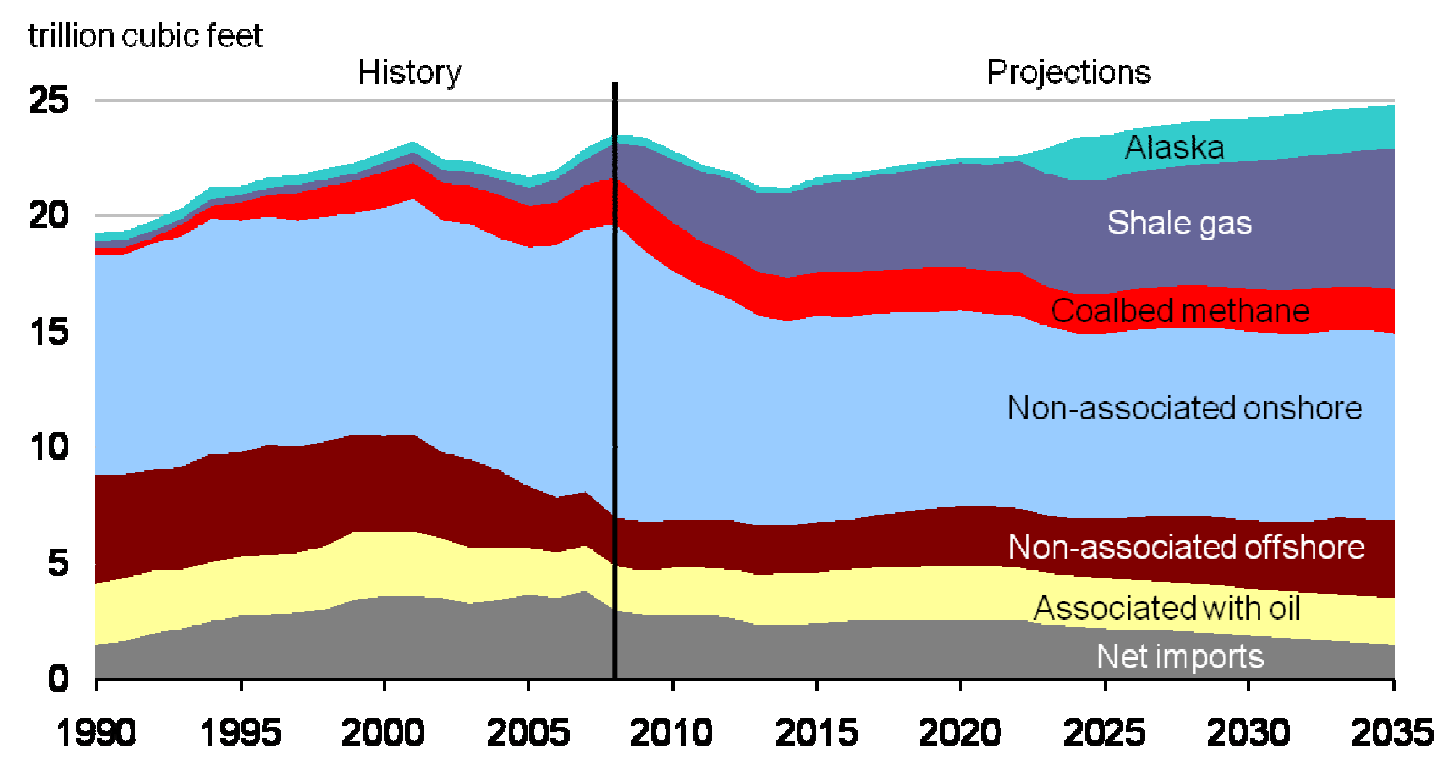

Fig. 1.7-Forecast of Shale Gas Growth in Meeting Energy Demand. (EIA, 2010b)

The US has more than 1,744 trillion cubic feet (Tcf) of technically recoverable natural gas, including 211 Tcf of proved reserves (the discovered, economically recoverable fraction of the OGIP) (EIA, 2007). Assuming that the US will continue to produce natural gas at approximately $20 \mathrm{Tcf} / \mathrm{yr}$, which is the same rate it was produced in 2007, the current technically recoverable resource estimate is enough natural gas to supply the US for the next 90 years (EIA, 2007). This is a conservative estimate; historically, analysts estimating the size of the total recoverable resource have been able 
to increase their estimates, including estimates of unconventional gas resources, as they have gained more knowledge about the available resources and as recovery technology has improved.

Between 1970 and 2006, the US produced approximately 725 Tcf of gas, and increased its natural gas reserves by $6 \%$ (BP, 2008.). This increase in reserves was mainly caused by advancements in technology, which meant that uneconomic volumes of gas became economically recoverable. Experts anticipate that as the US depletes its conventional gas reserves, more of its proved reserves will come from unconventional natural gas reservoirs. Since production from unconventional sources throughout the last decade has increased almost 65\%, from 5.4 trillion cubic feet per year (Tcf/yr) in 1998 to 8.9 Tcf/yr in 2007, this means that $46 \%$ of total US production now comes from unconventional production (Navigant, 2008.). Fig. 1.8 illustrates the forecasted increase daily production of unconventional in the U.S (DOE,2009).

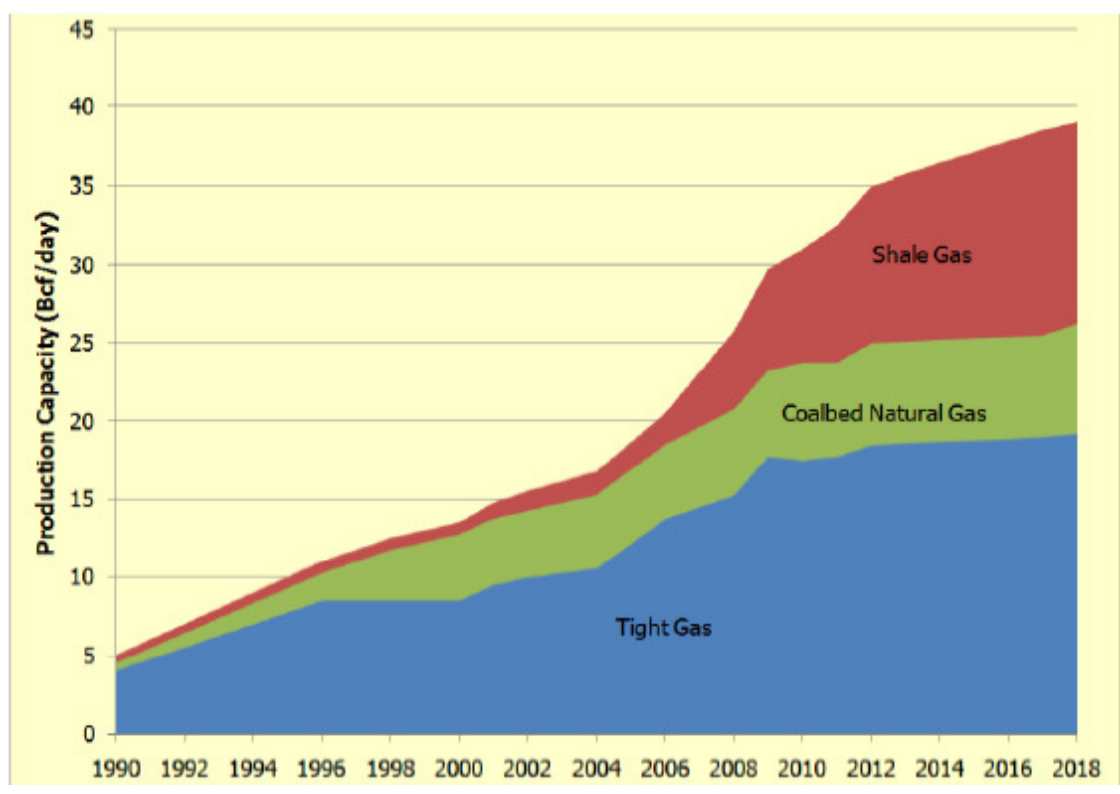

Fig. 1.8-Unconventional Natural Gas Outlook in the US (Bcf/day). (DOE, 2009) 


\section{THE QUESTION AND OBJECTIVES}

The objective of this research is to develop a methodology to quantify the impact of changes in the finding and development costs, lease operating expenses, and gas prices when estimating the economically recoverable resources (ERR) for unconventional gas plays. The methodology can be applied to rapidly determine the economically recoverable gas in unconventional resources given a range of prices F\&DC, and LOE. Primarily, the question being answered in this research is:

"Knowing the volume of technically recoverable resource (TRR) in an unconventional gas play, how is the volume of economically recoverable resource (ERR) affected by changes in F\&DC, LOE, and gas prices?"

More specifically, our goals for this research are:

- To develop a method to compute the economically recoverable resource in an unconventional gas reservoir;

- To apply the methodology to the Barnett Shale in North Texas and

- To illustrate how the ERR can be estimated as a function of finding and development costs, gas prices and lease operating expenses. 


\section{PROCEDURE}

The following procedure has been used during this research:

\subsection{Literature Review}

A literature review was conducted to identify the different factors affecting the calculation of ERR for the three types of unconventional gas resources (gas shale, tight gas, and coalbed methane). This review included identifying common investment criteria for unconventional gas development and management projects. The review covered SPE publications, EIA and USGS 2005 reports, theses, and dissertations.

\subsection{Case Study}

To develop a methodology to estimate ERR for unconventional gas resources, data from the EIA, IHS, Drilling Info, Joint Association Survey (JAS) on Drilling Costs, and Gas Technology Institute have been collected for the Barnett Shale to evaluate relations among TRR, F\&DC, LOE, gas prices, and ERR. The Barnett shale was selected as a case study for application of the proposed methodology.

To achieve our research objective, we first quantified the total resource and the technically recoverable gas for the play, generated cumulative distribution plots for EUR from currently producing wells, and then we applied specific investment criteria to generate different values of ERR as function of F\&DC, LOE, and gas prices. 


\section{FACTORS AFFECTING THE ESTIMATION OF ECONOMICALLY}

\section{RECOVERABLE GAS RESOURCES}

\subsection{Finding and Development Cost}

F\&D costs refer to the costs incurred by a company for purchasing and developing properties to establish commodity reserves. It includes the costs to obtain leases, costs to acquire, process, and interpret seismic data and drilling and development costs of a field.

F\&D costs have been slowly and steadily increasing for oil and gas (Fig. 4.1) for the past 10 years. An analysis of the F\&D costs for gas resources, including unconventional gas, shows that costs in the US have been increasing over the past five years. Current F\&D costs, however, are rising more rapidly. In 2009, F\&D costs increased to $\$ 25.50 /$ barrel of oil equivalent (BOE), which is $66 \%$ higher than the rate for 2008 (Fig. 4.1). The January 2009 issue of the Oil \& Gas Investor showed an average F\&D cost of $\$ 1.42 /$ Mcfe for the Marcellus Shale. Coker \& Palmer's drill-bit F\&D estimates were $\$ 1.50 / \mathrm{Mcfe}$. In 2008, F\&D costs for XTO Energy in the Barnett shale were $\$ 1.36 /$ Mcfe. In a report published by PICKERING in 2005, F\&D costs for the Barnett Shale ranged from $\$ 1.06$ to $\$ 1.71$ per Mcfe. F\&D costs vary between regions, but they have always been higher in the US than they are in most of the regions around the world (Fig. 4.2). These values of F\&D costs have caused a sharp drop-off in reserve revisions. 


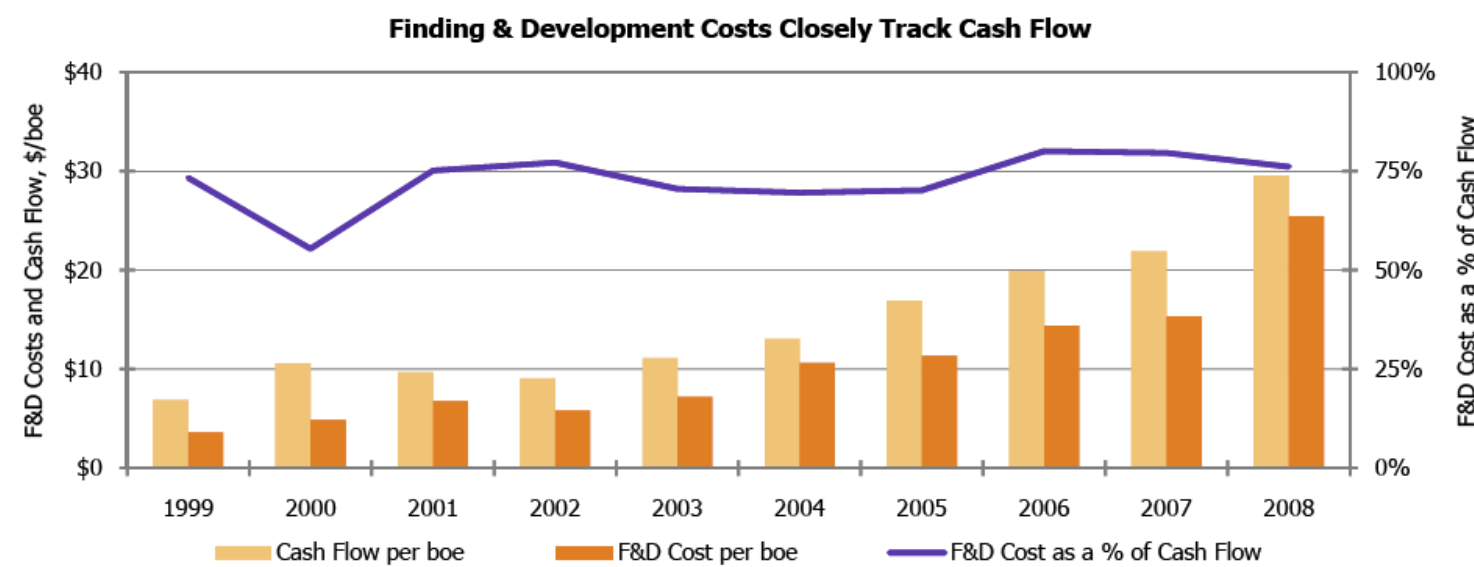

Fig. 4.1-Increasing F\&D Cost per BOE. (Herold, 2009)

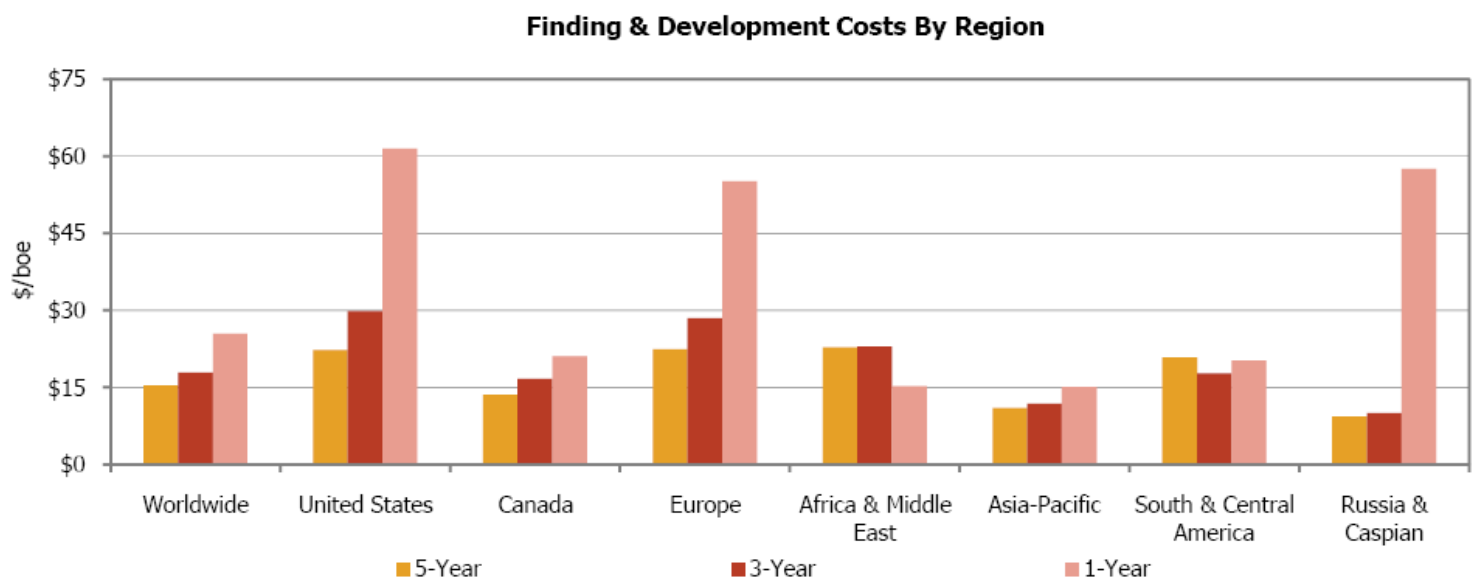

Fig. 4.2-F\&D Cost Vary between Regions. (Herold, 2009)

\subsection{Lease and Operating Expenses}

The Lease Operating Expenses (LOE) include the cost of producing oil and gas from a reservoir to a central gathering or shipping facility, and the cost of maintaining and operating oil and gas properties and equipment on a producing oil and gas lease. 
LOE incorporates the cost of labor, supplies, taxes, insurance, transportation, and other expenses related to equipments or jobs connected with a producing lease.

LOE for US unconventional plays typically range from $\$ 0.50$ to $\$ 2.00$ depending on location, reservoir quality, and tax regimes. Similar to F\&DC, LOE has been rising steadily over the years. According to the DOE (2009), LOE jumped by $30 \%$, approximately matching the steep rise in 2005, and were more than 2.5 times the level of four years ago, in 2009.

\subsection{Gas Prices}

Market supply and demand determine natural gas prices. In the short term, few alternatives exist for either production or consumption of natural gas. As such, when supply and demand are out of balance with respect to each other, large price changes result. On the supply side, changes in the amount of natural gas produced, imported, or stored all affect prices. Prices decrease when supplies increase, and increase when supplies decrease compared to demand. On the demand side, the main factors to consider are economic growth; the seasonal cycle of weather, especially between winter and summer; and the price of oil. Increased demand means increased gas prices; decreased demand brings prices down. 


\subsubsection{The Price Cycle}

In the United States, most of the natural gas being used has been produced domestically. When production declines gas prices usually increase. The increased prices can also finance increased drilling, which in time leads to more domestic production of natural gas. The recent economic recession caused natural gas consumption and prices to decline, starting during the last half of 2008 (Fig. 4.3).

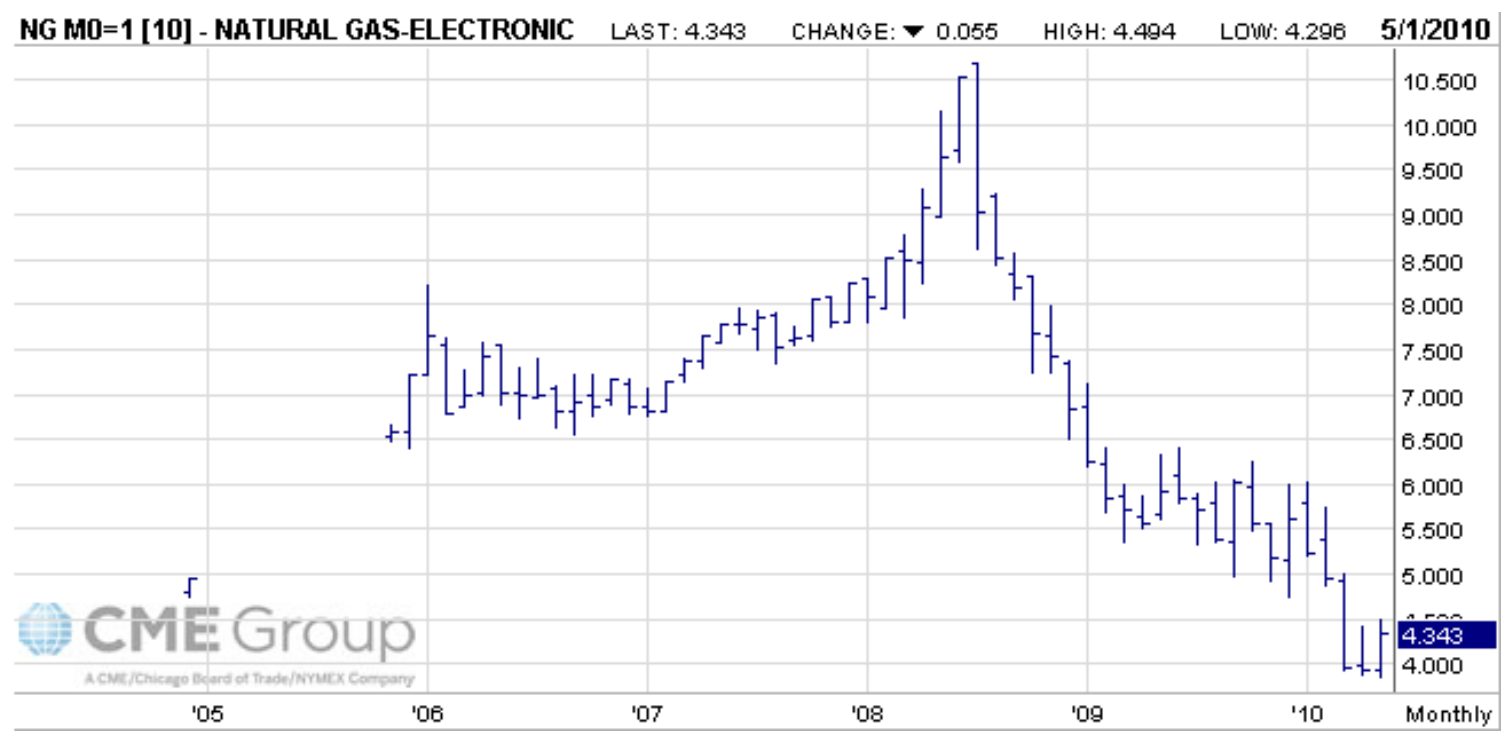

Fig. 4.3 - 2006-2010 Monthly Natural Gas Prices - Based on Henry Hub. (CME, 2010)

Decreased revenue leads to fewer gas-drilling rigs being in use; that, along with forecasts of continuing low demand, leads to decreased production of natural gas. Economic recovery means that industry will again increase its demand for natural gas. When it does, prices for natural gas should also increase. Natural gas wellhead prices are projected to rise from low levels experienced during 2008-2009 recession, according to 
the EIA (Fig. 4.4).To stabilize the gas prices, some producers and users are once again discussing the use of long-term contracts for natural gas.

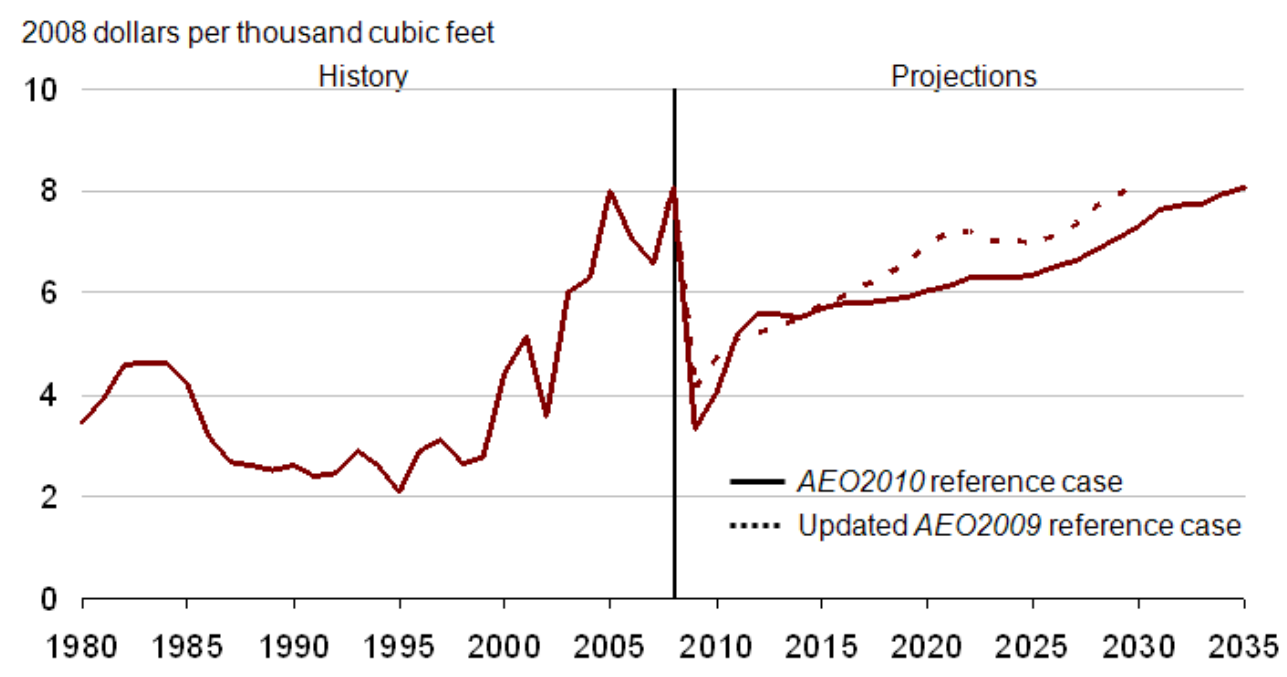

Fig. 4.4—Projected Natural Gas Prices. (EIA, 2010b)

\subsubsection{The Effect of Weather}

Seasonal changes and severe weather, such as hurricanes, can also affect the supply and the prices of natural gas. According to the EIA (2010a), the US Gulf Coast experienced summer hurricanes in 2005 that reduced total US natural gas production by 4\% from August 2005 until June 2006.

Natural gas is used during the winter to heat homes and businesses. In an unusually severe winter, prices may increase a great deal because it takes awhile to adjust the amount of natural gas being supplied so that it matches the sudden increased demand. The problem is made worse if the transportation system for the natural gas is at full capacity. The only way to respond to the sudden shortage is to increase prices enough to 
reduce demand. Sometimes, the weather is so severe that gas wells and pipelines freeze, which decreases supply when demand is at a high point.

Electric power plants are often fueled by natural gas, but the electricity produced during the summer months primarily powers air conditioning systems. If the summer is a hot one, the demand for air conditioning increases and the power plants require more natural gas in order to produce the necessary electricity. The price of natural gas increases as a result.

\subsubsection{Economic Activity}

Natural gas markets are also influenced by economic activity. A strong economy causes a greater demand for goods and services. As a result, the commercial and industrial sectors that produce those goods and services increase the demand for natural gas. In particular, this is true of the industrial sector, which uses natural gas to fuel its plants and to produce fertilizer and pharmaceuticals.

\subsubsection{Underground Storage}

The overall supply picture is also influenced by the level of gas held in underground storage fields. Underground storage fields of natural gas can increase the ability of companies to meet the suddenly increased needs for natural gas that sometimes occur, making it easier to maintain stable production rates, pipeline operations, and hub services. A storage field is an effective way to manage sudden shifts in supply and demand so that the process is smoother and less reactive. The refill season occurs from 
April to October, when there is less of a need for natural gas, and the stored gas may then be used during the heating season.

\subsubsection{Oil Prices}

For certain industrial consumers and generators of electricity, large-volume gas consumers can use both natural gas and oil as fuel. They switch between the two based on which one offers the lower price at the time. In addition, the markets for natural gas and coal can influence each other when natural gas prices fall or increase significantly. In some parts of the United States, coal-fired generation of electricity is not competitive if the cost of natural gas is low enough. Fuel markets do clearly interact with each other.If oil prices fall, demand shifts from natural gas to oil and natural gas prices go down. If oil prices rise, consumers may switch back to natural gas from oil, and the natural gas prices will go up(Fig. 4.5).

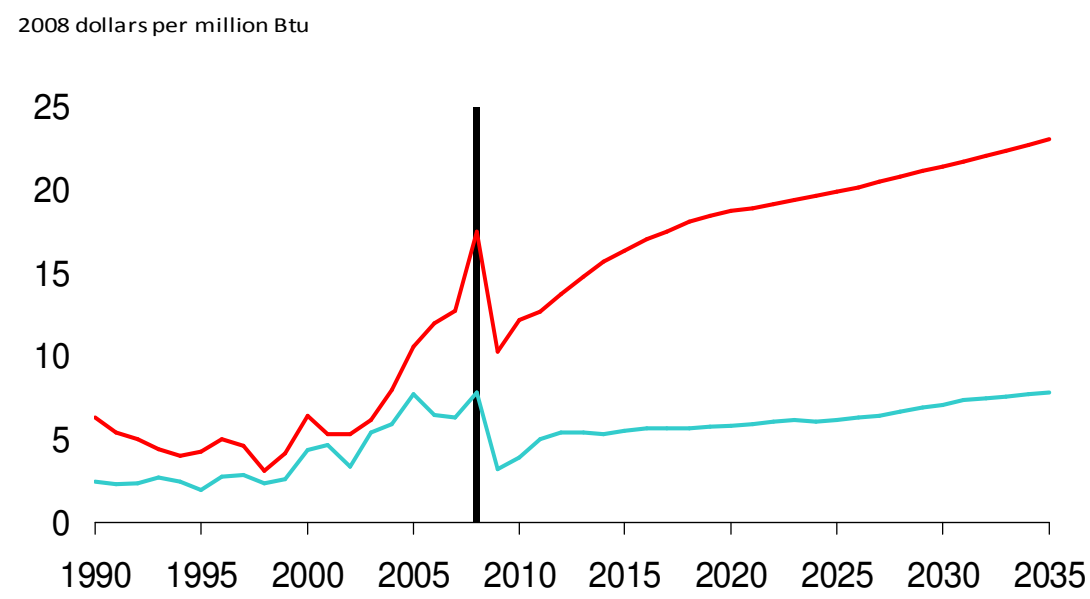

Fig. 4.5-Gas Prices Trail Oil Prices (EIA, 2010b) 


\section{INVESTMENT HURDLE: WHAT IS ECONOMICAL?}

\subsection{Abundant Resources}

With significant advances in horizontal drilling technologies, hydraulic fracturing, and generally higher natural gas prices in the past decade, unconventional gas reservoirs have become more economic to develop. The EIA estimates that TRR of natural gas in the US is more than 1,744 trillion cubic feet (Tcf) (EIA, 2007). Unconventional gas accounts for $60 \%$ of the onshore recoverable resource and shale gas accounts for $28 \%$ or more of natural gas TRR in the US (Navigant, 2008).Unconventional gas resources including coalbed methane, tight gas, and gas shale are abundant in the US. Shale gas are present across much of the lower 48 States (Fig. 5.1).

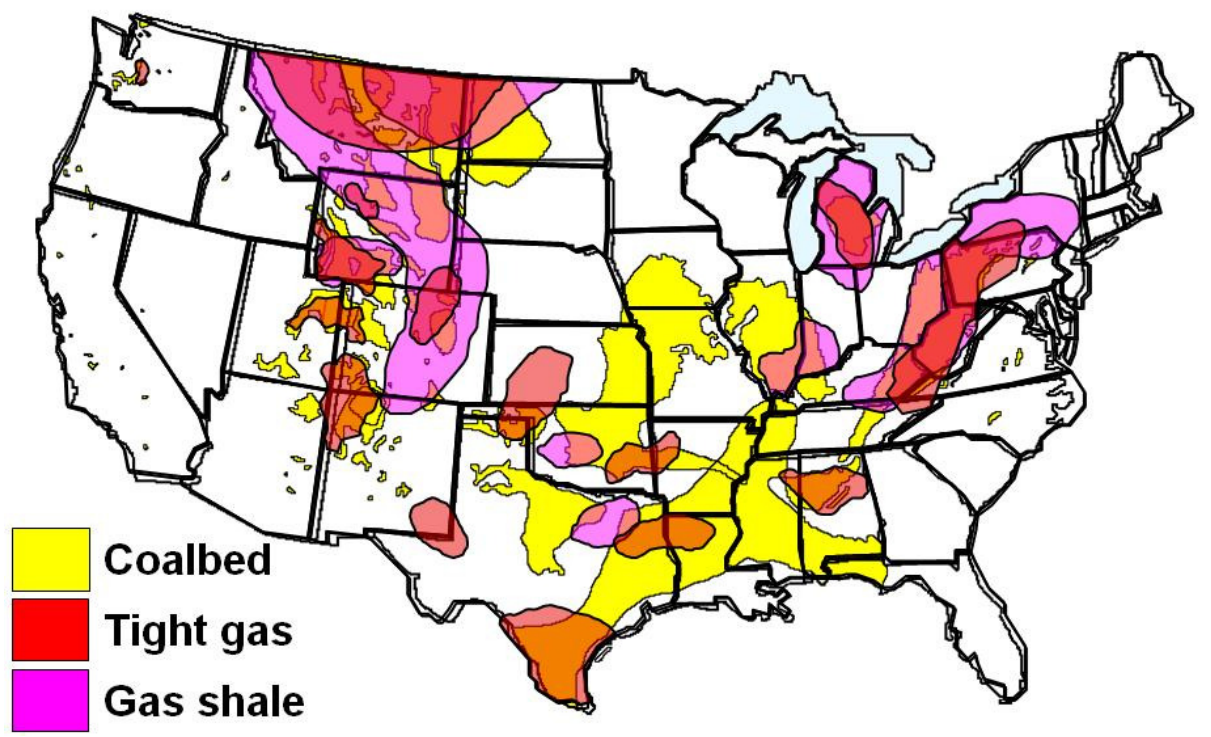

Fig. 5.1—United States 25 North American Basins (Singh, 2006) 
Fig. 5.2 shows approximate locations for currently producing or prospective gas shales. In 2008, the most active shale gas plays were the Barnett, the Haynesville/Bossier, the Antrim, the Fayetteville, the Marcellus, and the New Albany (DOE,2009).

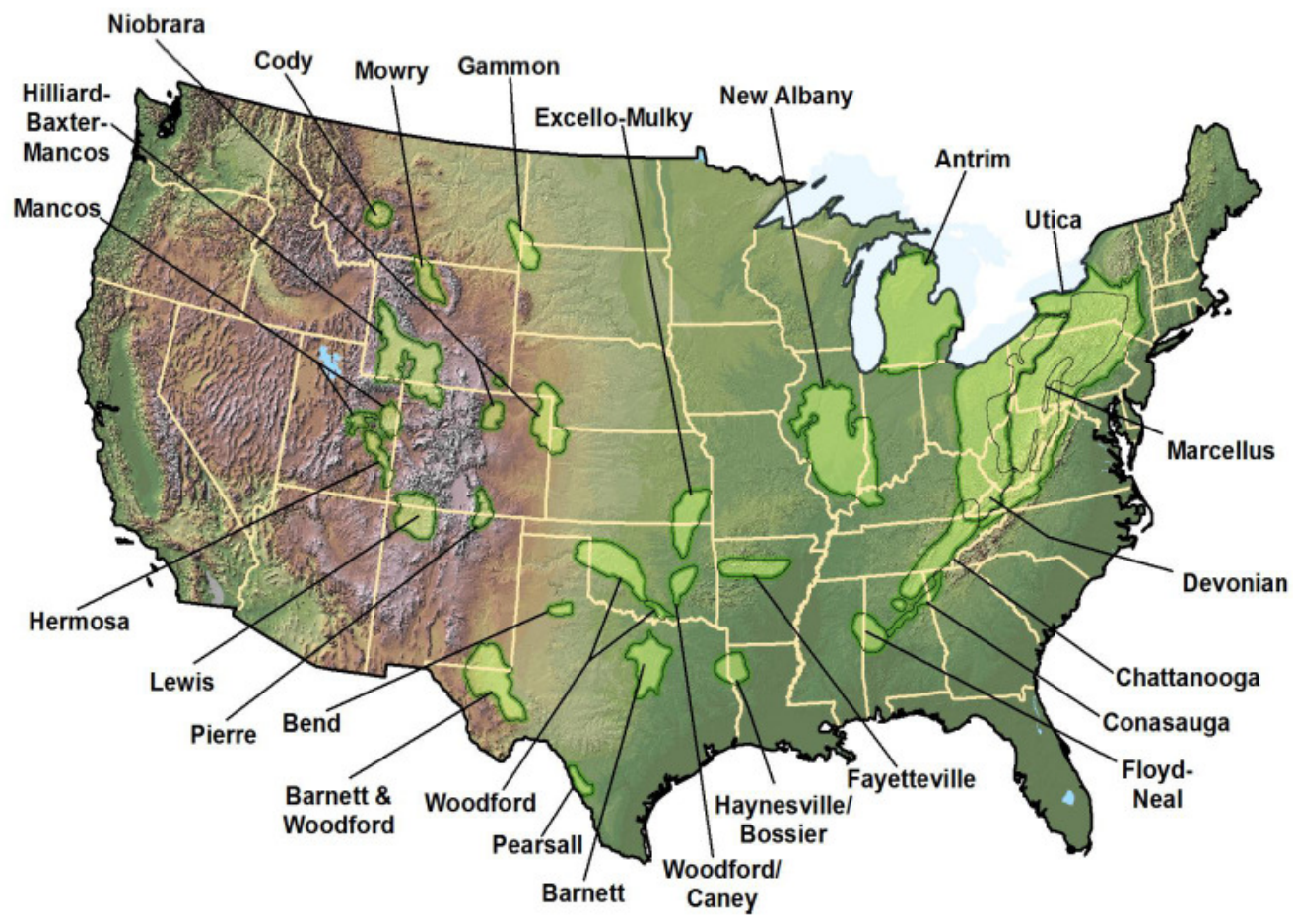

Fig. 5.2-United States Shale Gas Basins. (DOE, 2009)

Table 5.1—TRR for United States Shale Gas Basins. (Navigant, 2008)

\begin{tabular}{|c|c|c|c|c|c|c|}
\hline Barnett & Fayetteville & Haynesville & Marcellus & Woodford & Antrim & New Albany \\
\hline $44 \mathrm{Tcf}$ & $41.6 \mathrm{Tcf}$ & $251 \mathrm{Tcf}$ & $262 \mathrm{Tcf}$ & $11.4 \mathrm{Tcf}$ & $20 \mathrm{Tcf}$ & $19.2 \mathrm{Tcf}$ \\
\hline
\end{tabular}

To illustrate how rapid the situation can change, one of the most active plays in the US is now the Eagle Ford Shale in South Texas. The Eagle Ford Shale was not even mentioned in the DOE (2009) report (Table 5.1). 


\subsection{Investment Hurdle Criteria}

There could be several methods to determine what is considered economic. Many engineers use a PV10 value greater than zero as an indication the well is economic. We chose to use another definition that relies mainly on Payout and ROR. In this research, a resource is considered economical if, in a typical well-life of 25years, the wellpays out its finding and development cost in five years or less and makes at least $20 \%$ rate of return. 


\section{CASE STUDY: THE BARNETT SHALE}

\subsection{The Barnett Shale: A Hot Play}

The Barnett Shale play is located at depths of 6,500-8,500 feet. It is a Mississippianage shale with net thickness ranging from 100 to $600 \mathrm{ft}$. The Total Organic Content (TOC) is averaged at $4.5 \%$. The total porosity is $4-5 \%$. According to DOE (2009), the Barnett Shale has an OGIP of 327 Tcf and an estimated TRR of 44 Tcf.

The Barnett Shale play spans 20 to 24 counties in the Fort Worth Basin of north Texas (Fig. 6.1). The shale's eastern border is the Ouachita Thrust-fold Belt and the Muenster Arch; the western border is the Bend Arch. Heading northeast in the play, the Forestburg limestone splits the Barnett into the upper and lower Barnett. Most development has focused on the Lower Barnett.

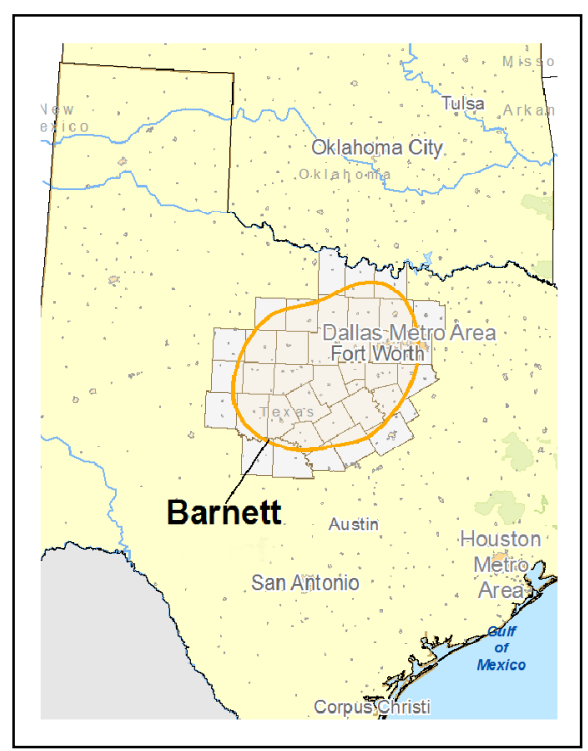

Fig. 6.1-Barnett Shale in the Fort Worth Basin.(DOE,2009) 
Table 6.1—Barnett Shale Counties. (Texas Railroad Commission, 2010)

\begin{tabular}{|c|c|c|}
\hline Core Counties & \multicolumn{2}{|c|}{ Non-Core Counties } \\
\hline Denton & Archer & Hood \\
Johnson & Bosque & Jack \\
Tarrant & Clay & Montague \\
Wise & Comanche & Palo Pinto \\
& Cooke & Parker \\
& Coryell & Shakleford \\
& Dallas & Somervell \\
& Eastland & Stephens \\
& Ellis & \\
& Erath & \\
& Hamilton & \\
& Hill & \\
\hline
\end{tabular}

Most Barnett Shale production has been in the Newark East Field, which covers part of Denton, Wise Tarrant, and Johnson Counties (Table 6.1). The term "core area" typically describes all four of these counties, but the most productive part is Newark East, which spans Denton, Wise, and Tarrant counties. Before the advancement of horizontal drilling, companies usually drilled the core area with vertical wells and completed them with large hydraulic fracture treatments. A limestone barrier, which separates the core of the Barnett Shale from the underlying water-bearing Ellenberger formation, made it possible for companies to pump large fracture treatments. The core is the thickest, deepest part of the Barnett Shale, and it is also the location of the Barnett's highest gas-in-place per section (square mile). 
The non-core area of the Barnett Shale is located north, south and west of the core area. According to Hayden (2005), the Viola Limestone separates the core area from underlying water-bearing formations. In the non-core area where Viola is absent, however, vertical wells with large hydraulic fracture treatments are at risk of communicating with the underlying water-bearing Ellenburger formation. To avoid the problem, companies have effectively used horizontal drilling and multiples of smaller hydraulic fracture treatments along the horizontal well section. The far west and south areas of the Fort West basin is the least-developed area. Results from conventional analysis suggest that a large portion of these areas will produce oil instead of gas (Hayden, 2005).

Companies that are attempting to develop the non-core area are trying to identify the west side of the oil-gas window, but without much success yet. In addition to the fact that they don't know how far west they can successfully find gas instead of oil, the west and south shale itself is thinner and shallower. As a result, companies produce lower amounts of gas-in-place and recovery per section than the Core area. Moreover, the base of the Barnett does not have a competent fracture barrier, so most operators are using horizontal wells, which are more expensive, to develop the resource. Since 2006, more drilling has been taking place on the non-core area.

The rig count in the play has increased as many of the larger players have added rigs. Currently, production from the Barnett is approximately $1.7 \mathrm{Tcf} / \mathrm{d}$ (Fig. 6.2). It accounts for more than $6 \%$ of all natural gas produced in the lower 48 States (DOE, 2009). 


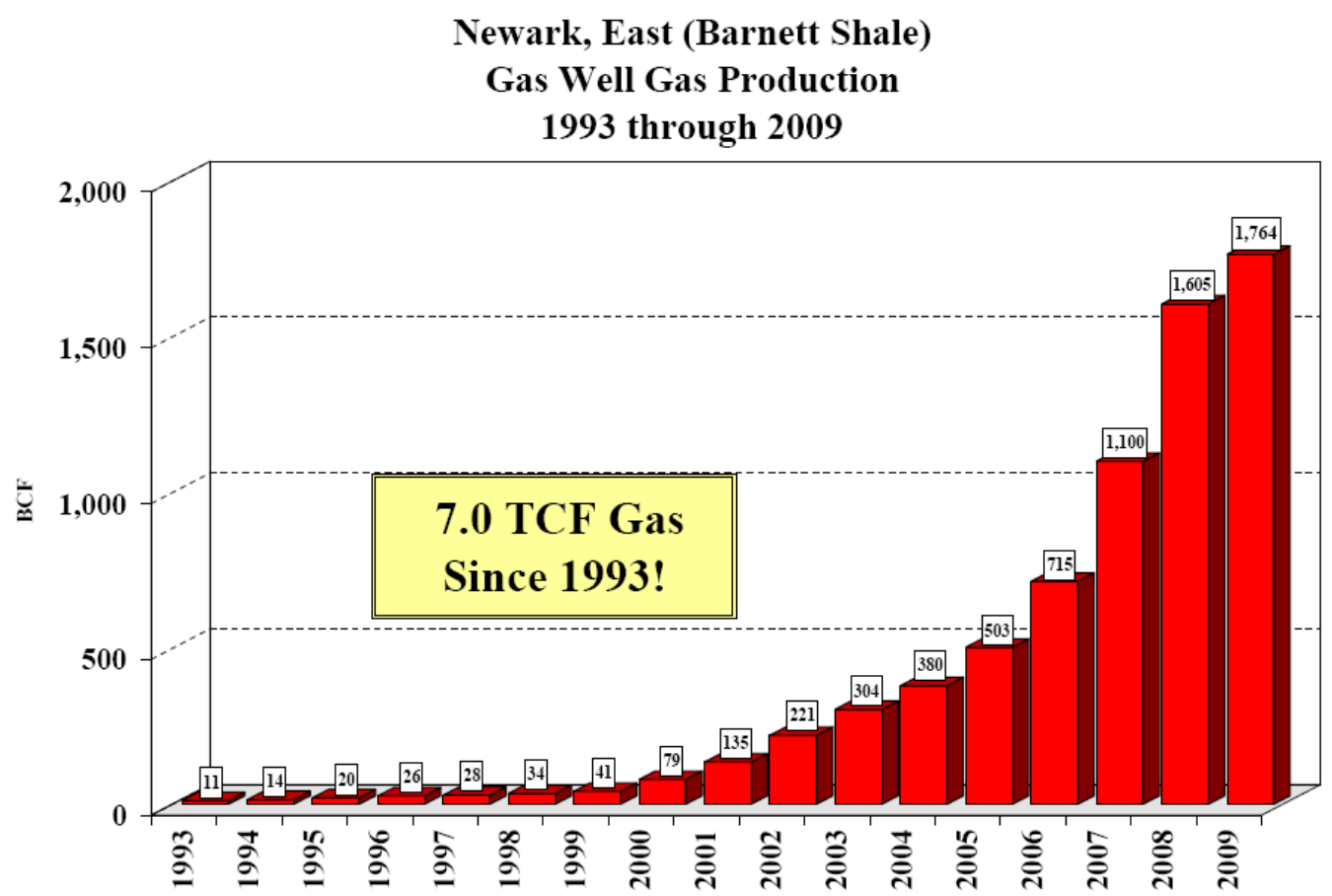

Fig. 6.2-Barnett Shale Annual Total Gas Production. (Texas Railroad Commission, 2010)

Since 1993, more than 13,000 wells have been drilled in the Barnett, far outside its original core area, due to significant developments in horizontal drilling and light sand fracturing (Fig. 6.3). The combination of sequenced hydraulic fracture treatments and horizontal well completions has been crucial in facilitating the expansion of shale gas development (DOE, 2009). 


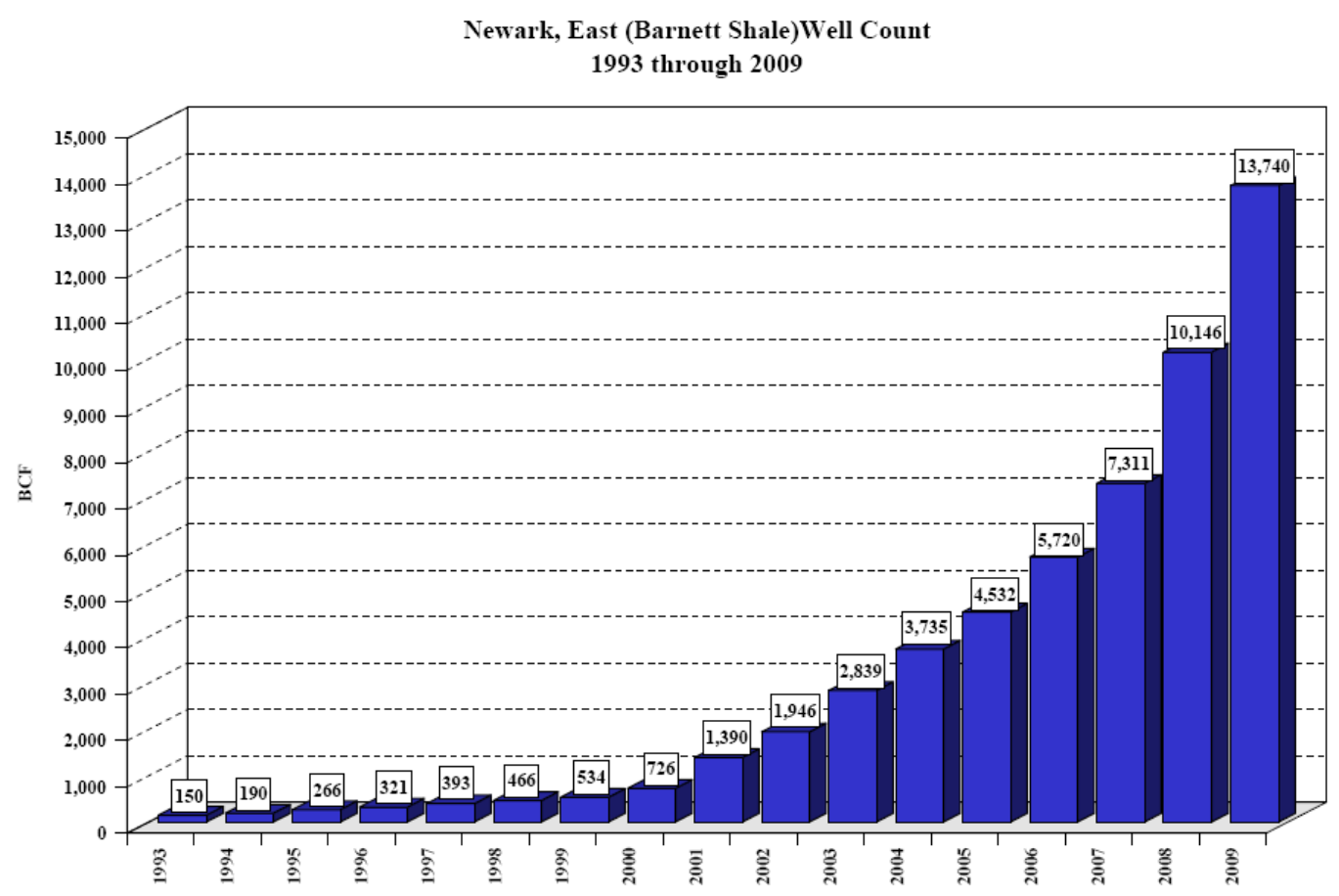

Fig. 6.3-Barnett Shale Well Count from 1993 through 2009. (Texas Railroad

Commission, 2010)

According to the Texas Railroad Commission (2010), 1,162 well permits were issued through August 2009. In addition, the field produced 809billion cubic feet (Bcf) of natural gas during the first six months of 2009.

\subsection{Barnett Shale Production Profile}

To study the economics of producing gas from the Barnett Shale, EUR values were obtained for approximately 14,000 wells that have been drilled since 1980.The EUR values were calculated by Unconventional Gas Resources LLC, with a $6 \%$ terminal decline rate. These data were loaded in @Risk® and a log-normal distribution was fitted 
through the EUR values, which were ranked from lowest to highest. After fitting a distribution through the EUR values, we ran Monte Carlo simulation runs (with 100,000 random EUR values) to generate a Cumulative Distribution graph. A cumulative distribution plot shows on the $y$-axis the percentage of data samples that have a value lower than the value on the $x$-axis.

The simulation results provided a probabilistic distribution with a P10 value of .250 Bcf, a P50 of 1.5 Bcf, and a P90 of 4.0 Bcf. This can be interpreted as follows:

- $\quad 90 \%$ of the Barnett Shale wells have an EUR of .250 Bcf or more.

- $\quad 50 \%$ of the Barnett Shale wells have an EUR of 1.5 Bcf

- $\quad 10 \%$ of the Barnett Shale wells have an EUR of 4.0 Bcf or more.

Based on this distribution, the economic analysis in the next section will be performed on three wells representing the $10^{\text {th }}$ percentile, $50^{\text {th }}$ percentile, and $90^{\text {th }}$ percentile, respectively (Table 6.2).

Table 6.2_EUR Values for P10 Well, P50 Well, and P90 Well.

\begin{tabular}{|c|c|c|c|}
\hline & P10 Well & P50 Well & P90 Well \\
\hline EUR (Bcf) & .250 & 1.5 & 4.0 \\
\hline Percentile & $10^{\text {th }}$ & $50^{\text {th }}$ & $90^{\text {th }}$ \\
\hline
\end{tabular}

\subsection{Production Forecast Using Hyperbolic Decline Curves}

To create the production profile for P10 Well, P50 Well, and P90, hyperbolic decline curves were used to generate a 40-year production forecast for each well. Hyperbolic decline curves are concave upward curves when plotted on semi-logarithmic graph paper and expressed by the following equations: 


$$
q_{(t)}=\frac{q_{(i)}}{\left(1+b D_{i} t\right)^{1 / b}} G_{p(t)}=\left(\frac{q_{(i)}^{b}}{D_{i}(b-1)}\right)\left\{q_{(t)}^{(1-b)}-q_{(i)}^{(1-b)}\right\}
$$

where:

$q_{(t)}=$ production rate at time $\mathrm{t}$, (volume/time)

$q_{(i)}=$ production rate at time $\mathrm{t}=0,($ volume/time $)$

$D_{(i)}=$ Initial nominal decline rate at $\mathrm{t}=0,(1 /$ time $)$

$b=$ hyperbolic exponent

$t=$ time

$G_{p(t)}=$ Cumulative production for time t.

The $b$ value ranges between 0 and 1 , where at $b=0$ the hyperbolic decline becomes exponential decline and at $b=1$, the hyperbolic decline becomes harmonic. However, it is found that in fractured low-permeability formations, the value of exponent b can be calculated (Mian 2002).Since we only have EUR estimates without production history to match, we used trial and error to determine $q_{(i)}, D_{(i)}$, and $b$ values which yield the specified EUR values in a 40-year well life. Table 6.3 shows the values used for generating each production profile. A 10\% minimum decline rate was imposed. Fig. 6.4 illustrates the production forecast for each well.

Table 6.3-Input to the Hyperbolic Decline Curve for P10, P50, and P90 Wells.

\begin{tabular}{|c|c|c|c|}
\hline & P10 & P50 & P90 \\
\hline$q_{(i)}($ Mcf/d) & 700 & 1600 & 1500 \\
\hline$D_{(i)}$ & 40 & 10 & .5 \\
\hline$b$ & 2 & 2.53 & 2.52 \\
\hline EUR (Bcf) & .250 & 1.50 & 4 \\
\hline Min. decline rate & $10 \%$ & $10 \%$ & $10 \%$ \\
\hline
\end{tabular}




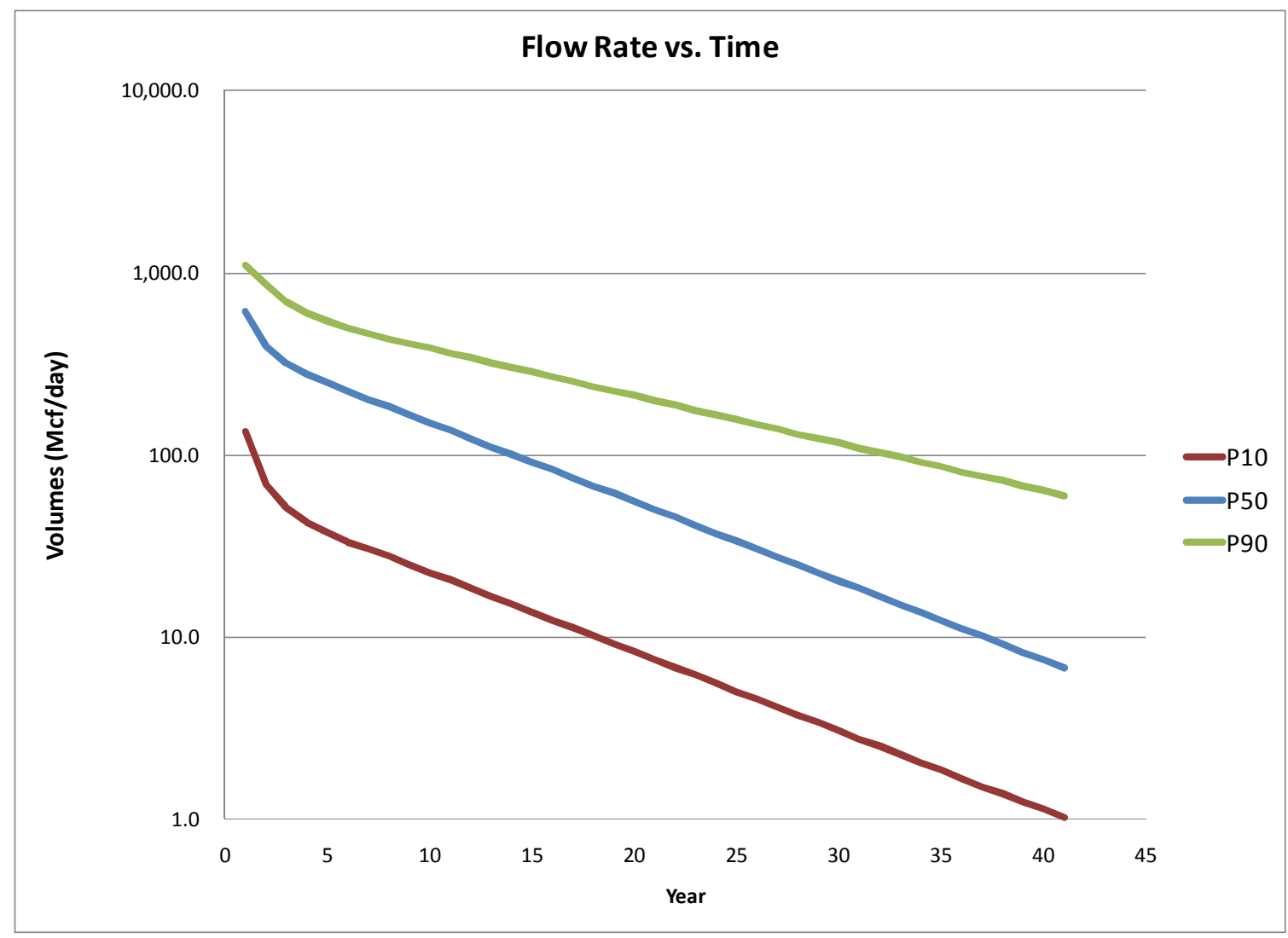

Fig. 6.4-40-Year Production Forecast for P10, P50, and P90 Wells.

With the 40-year production forecastfor each well generated, the first 25-year production profile was captured to economically study each well (Fig. 6.5) 


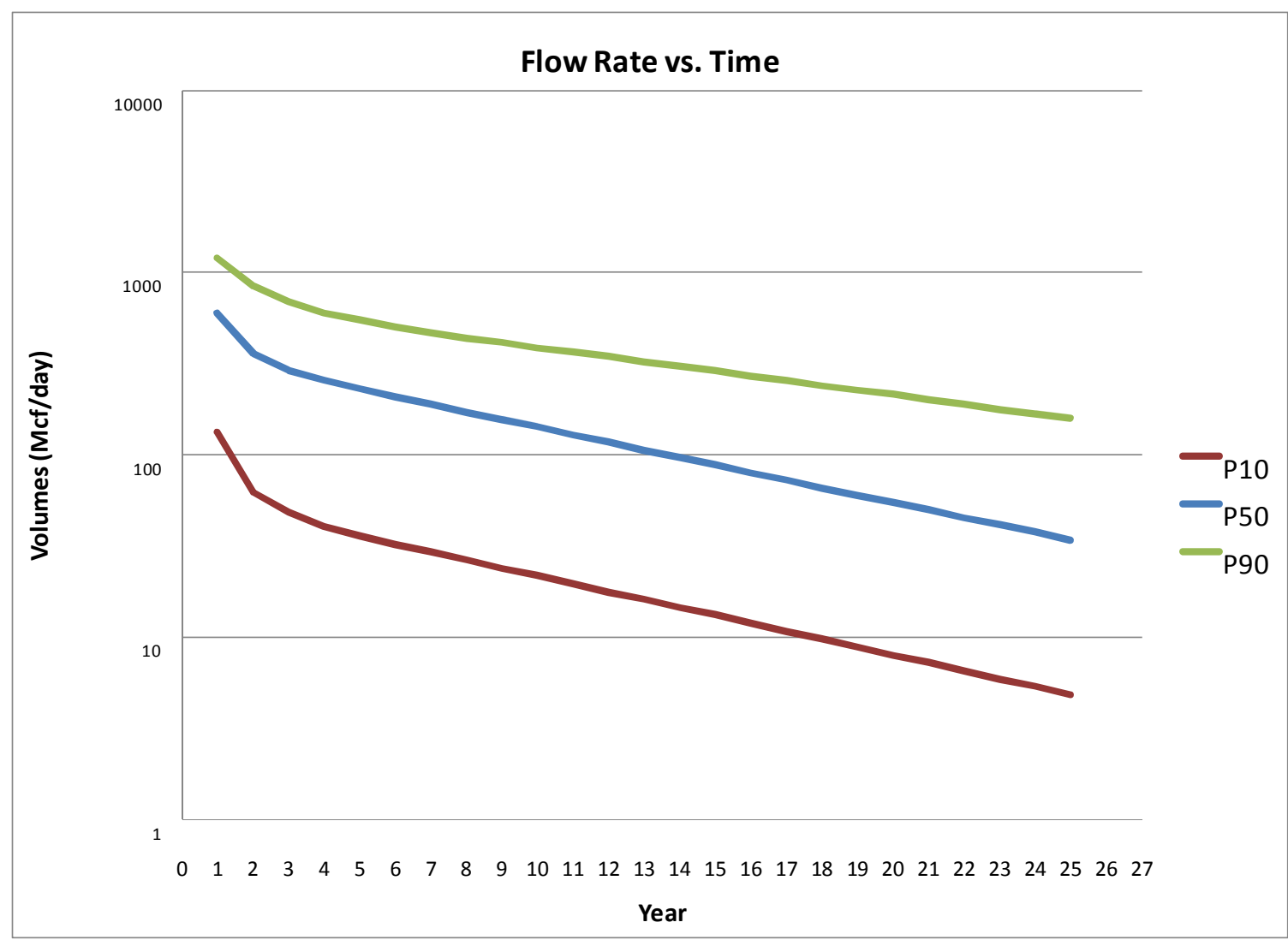

Fig. 6.5-25-Year Production Forecast for P10, P50, P90 Wells.

Using the forecast production from the hyperbolic decline curves, 25-year cumulative production data were calculated for each well (Table 6.4). The 25-year cumulative production for each well were used to generate a scaled 25-year cumulative production profile that fully exploties each EUR during the well life, which was set for 25 years in this study, for P10, P50, and P50 percentiles (Table 6.5). 
Table 6.4-25-Year Production Profile before Scaling.

\begin{tabular}{|c|c|c|c|}
\hline Years & P10 (Mcf) & P50 (Mcf) & P90 (Mcf) \\
\hline 1 & 0 & 0 & 0 \\
\hline 2 & 51,135 & 237,688 & 430,936 \\
\hline 3 & 74,712 & 376,502 & 733,030 \\
\hline 4 & 92,837 & 489,665 & 981,815 \\
\hline 5 & 108,128 & 588,735 & $1,199,066$ \\
\hline 6 & 121,605 & 678,043 & $1,394,782$ \\
\hline 7 & 133,755 & 758,851 & $1,574,552$ \\
\hline 8 & 144,749 & 831,970 & $1,741,888$ \\
\hline 9 & 154,697 & 898,130 & $1,899,074$ \\
\hline 10 & 163,698 & 957,994 & $2,047,104$ \\
\hline 11 & 171,843 & $1,012,162$ & $2,186,514$ \\
\hline 12 & 179,212 & $1,061,175$ & $2,317,805$ \\
\hline 13 & 185,880 & $1,105,523$ & $2,441,450$ \\
\hline 14 & 191,914 & $1,145,652$ & $2,557,895$ \\
\hline 15 & 197,373 & $1,181,961$ & $2,667,558$ \\
\hline 16 & 202,313 & $1,214,815$ & $2,770,835$ \\
\hline 17 & 206,783 & $1,244,543$ & $2,868,098$ \\
\hline 18 & 210,827 & $1,271,442$ & $2,959,697$ \\
\hline 19 & 214,487 & $1,295,781$ & $3,045,961$ \\
\hline 20 & 217,798 & $1,317,804$ & $3,127,202$ \\
\hline 21 & 220,795 & $1,337,731$ & $3,203,712$ \\
\hline 22 & 223,506 & $1,355,762$ & $3,275,766$ \\
\hline 23 & 225,959 & $1,372,077$ & $3,343,624$ \\
\hline 24 & 228,178 & $1,386,839$ & $3,407,530$ \\
\hline 25 & 230,187 & $1,400,197$ & $3,467,714$ \\
\hline 26 & 232,004 & $1,412,283$ & $3,524,394$ \\
\hline
\end{tabular}


Table 6.5-25-Year Production Profile after Scaling to Produce All EUR.

\begin{tabular}{|c|c|c|c|}
\hline Years & P10 (Mcf) & P50 (Mcf) & P90 (Mcf) \\
\hline 1 & 0 & 0 & 0 \\
\hline 2 & 53,979 & 245,714 & 489,090 \\
\hline 3 & 79,313 & 391,309 & 831,951 \\
\hline 4 & 98,887 & 510,104 & $1,114,308$ \\
\hline 5 & 115,456 & 614,083 & $1,360,877$ \\
\hline 6 & 130,089 & 707,809 & $1,583,003$ \\
\hline 7 & 143,286 & 792,728 & $1,787,033$ \\
\hline 8 & 155,228 & 869,759 & $1,976,950$ \\
\hline 9 & 166,032 & 939,700 & $2,155,348$ \\
\hline 10 & 175,809 & $1,003,226$ & $2,323,355$ \\
\hline 11 & 184,655 & $1,060,933$ & $2,481,577$ \\
\hline 12 & 192,660 & $1,113,363$ & $2,630,585$ \\
\hline 13 & 199,902 & $1,161,005$ & $2,770,916$ \\
\hline 14 & 206,456 & $1,204,303$ & $2,903,075$ \\
\hline 15 & 212,386 & $1,243,659$ & $3,027,537$ \\
\hline 16 & 217,751 & $1,279,438$ & $3,144,751$ \\
\hline 17 & 222,606 & $1,311,970$ & $3,255,139$ \\
\hline 18 & 226,999 & $1,341,556$ & $3,359,099$ \\
\hline 19 & 230,974 & $1,368,467$ & $3,457,004$ \\
\hline 20 & 234,570 & $1,392,949$ & $3,549,208$ \\
\hline 21 & 237,825 & $1,415,226$ & $3,636,042$ \\
\hline 22 & 240,769 & $1,435,500$ & $3,717,820$ \\
\hline 23 & 243,434 & $1,453,956$ & $3,794,835$ \\
\hline 24 & 245,845 & $1,470,759$ & $3,867,365$ \\
\hline 25 & 248,026 & $1,486,062$ & $3,935,672$ \\
\hline 26 & 250,000 & $1,500,000$ & $4,000,000$ \\
\hline
\end{tabular}

Fig. 6.6 illustrates the cumulative production data throughout the 25-year life for each well. 


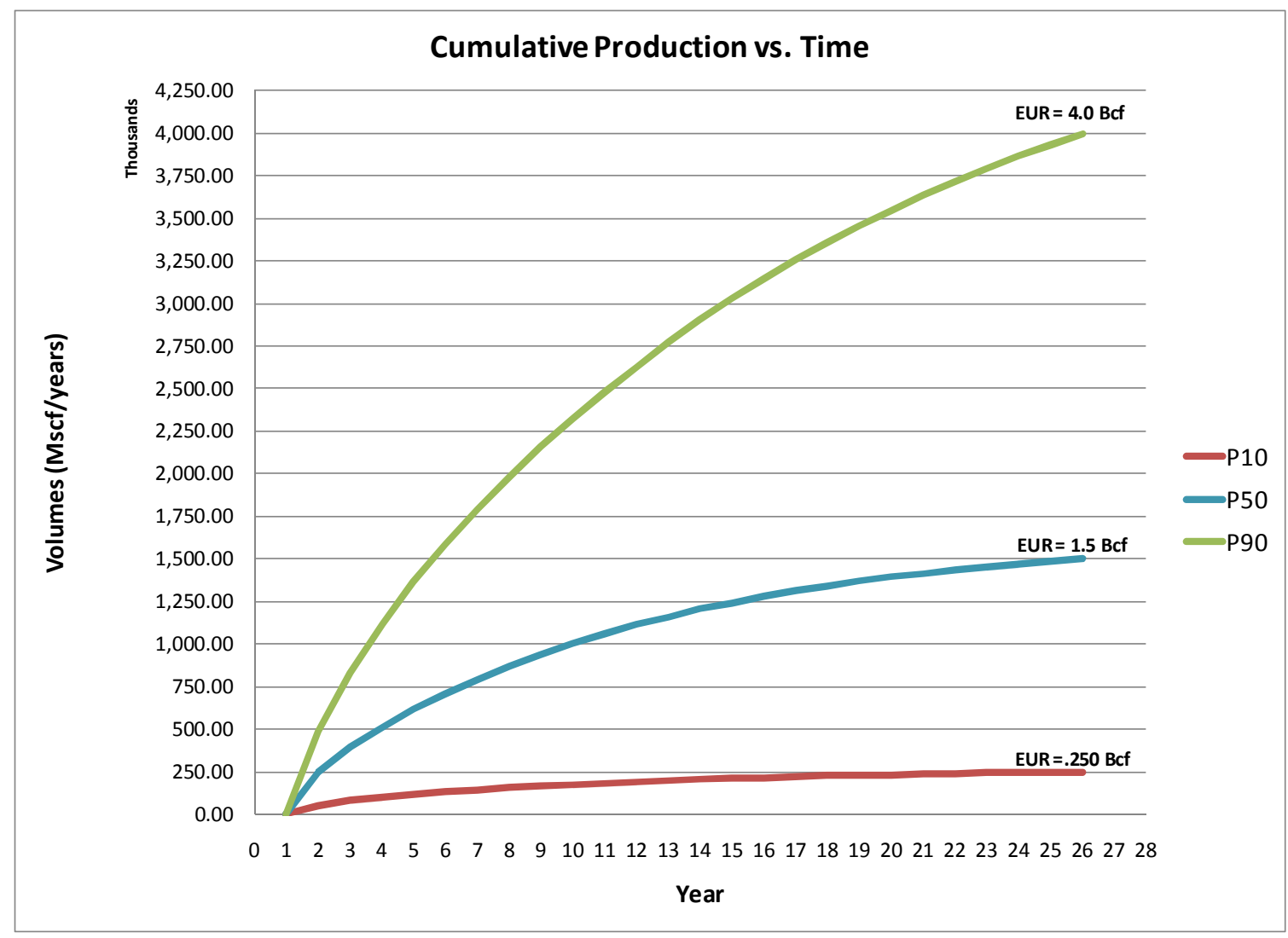

Fig. 6.6-25-Year Cumulative Production for P10, P50, and P90 Wells. 


\title{
7 ECONOMIC ANALYSIS
}

\subsection{Well-Level Economics: Scenario I}

As a starting point, the economic analysis below will be performed using the following assumptions:

\author{
Assumptions for Scenario I \\ - F\&DC of \$2 million; \\ - $0 \%$ royalty burden; \\ - $100 \%$ probability of success; \\ - $0 \%$ escalation of gas prices and costs; \\ - $\quad 0 \%$ fuel and shrinkage; \\ - LOE of $\$ 1.0 / \mathrm{Mcf} ;$ and \\ - $\quad 10 \%$ annual discount rate.
}

Fuel shrinkage results from the usage of a percentage of produced gas for mechanical compression along the pipeline. The well life used for the analysis is 25 years with a $10 \%$ annual discount rate. In section 7.2, more realistic assumptions will be used.

\subsubsection{Economics for P10, P50, P90 Wells at Scenario I}

With the 25 -year production profile for the three wells, representing the $10^{\text {th }}, 50^{\text {th }}$, and $90^{\text {th }}$ percentiles, we ran economics on each well, calculating the required gas price 
that yields an ROR greater than or equal to $20 \%$ and pays out the initial investment (F\&DC) in five years or less. We ran several economical scenarios, with F\&DC ranging from $\$ 250,000$ per well to $\$ 400,000$, in increments of $\$ 250,000$ (Table 7.1).

Table 7.1-Gas Prices to Meet Investment Hurdle at Different F\&D Costs at Scenario I

\begin{tabular}{|cc|cc|cc|}
\hline EUR (Bcf) & $\mathbf{0 . 2 5}$ & $\begin{array}{c}\text { EUR (Bcf) } \\
\text { P50 }\end{array}$ & 1.5 & EUR (Bcf) & 4.00 \\
\hline F\&DC & $\begin{array}{c}\text { Gas Price } \\
\text { per Mcf }\end{array}$ & F\&DC & $\begin{array}{c}\text { Gas Price } \\
\text { per Mcf }\end{array}$ & F\&DC & $\begin{array}{c}\text { Gas Price } \\
\text { per Mcf }\end{array}$ \\
$\$ 250,000$ & $\$ 3.40$ & $\$ 250,000$ & $\$ 1.50$ & $\$ 250,000$ & $\$ 1.20$ \\
$\$ 500,000$ & $\$ 5.70$ & $\$ 500,000$ & $\$ 1.90$ & $\$ 500,000$ & $\$ 1.40$ \\
$\$ 750,000$ & $\$ 8.10$ & $\$ 750,000$ & $\$ 2.30$ & $\$ 750,000$ & $\$ 1.60$ \\
$\$ 1,000,000$ & $\$ 10.40$ & $\$ 1,000,000$ & $\$ 2.80$ & $\$ 1,000,000$ & $\$ 1.80$ \\
$\$ 1,250,000$ & $\$ 12.80$ & $\$ 1,250,000$ & $\$ 3.20$ & $\$ 1,250,000$ & $\$ 2.00$ \\
$\$ 1,500,000$ & $\$ 15.10$ & $\$ 1,500,000$ & $\$ 3.60$ & $\$ 1,500,000$ & $\$ 2.20$ \\
$\$ 1,750,000$ & $\$ 17.50$ & $\$ 1,750,000$ & $\$ 4.10$ & $\$ 1,750,000$ & $\$ 2.40$ \\
\hline$\$ 2,000,000$ & $\$ 19.80$ & $\$ 2,000,000$ & $\$ 4.50$ & $\$ 2,000,000$ & $\$ 2.60$ \\
\hline$\$ 2,250,000$ & $\$ 22.20$ & $\$ 2,250,000$ & $\$ 4.90$ & $\$ 2,250,000$ & $\$ 2.70$ \\
$\$ 2,500,000$ & $\$ 24.50$ & $\$ 2,500,000$ & $\$ 5.40$ & $\$ 2,500,000$ & $\$ 2.90$ \\
$\$ 2,750,000$ & $\$ 26.90$ & $\$ 2,750,000$ & $\$ 5.80$ & $\$ 2,750,000$ & $\$ 3.10$ \\
$\$ 3,000,000$ & $\$ 29.20$ & $\$ 3,000,000$ & $\$ 6.20$ & $\$ 3,000,000$ & $\$ 3.30$ \\
$\$ 3,250,000$ & $\$ 31.60$ & $\$ 3,250,000$ & $\$ 6.70$ & $\$ 3,250,000$ & $\$ 3.50$ \\
$\$ 3,500,000$ & $\$ 33.90$ & $\$ 3,500,000$ & $\$ 7.10$ & $\$ 3,500,000$ & $\$ 3.70$ \\
$\$ 3,750,000$ & $\$ 36.30$ & $\$ 3,750,000$ & $\$ 7.50$ & $\$ 3,750,000$ & $\$ 3.90$ \\
$\$ 4,000,000$ & $\$ 38.60$ & $\$ 4,000,000$ & $\$ 8.00$ & $\$ 4,000,000$ & $\$ 4.10$ \\
\hline
\end{tabular}

As the EUR increases, the required gas price to meet our investment-hurdle decreases (Fig. 7.1). For example, a Barnett Shale well with an EUR of 1.5 Bcf that costs $\$ 2$ million to be drilled and completed will require agas price of $\$ 4.5 / \mathrm{Mcf}$ before it can be considered economical, while a $4.0-\mathrm{Bcf}$ well with the same F\&DC will require a gas price of $\$ 2.6 / \mathrm{Mcf}$ before it will be worth the investment. 


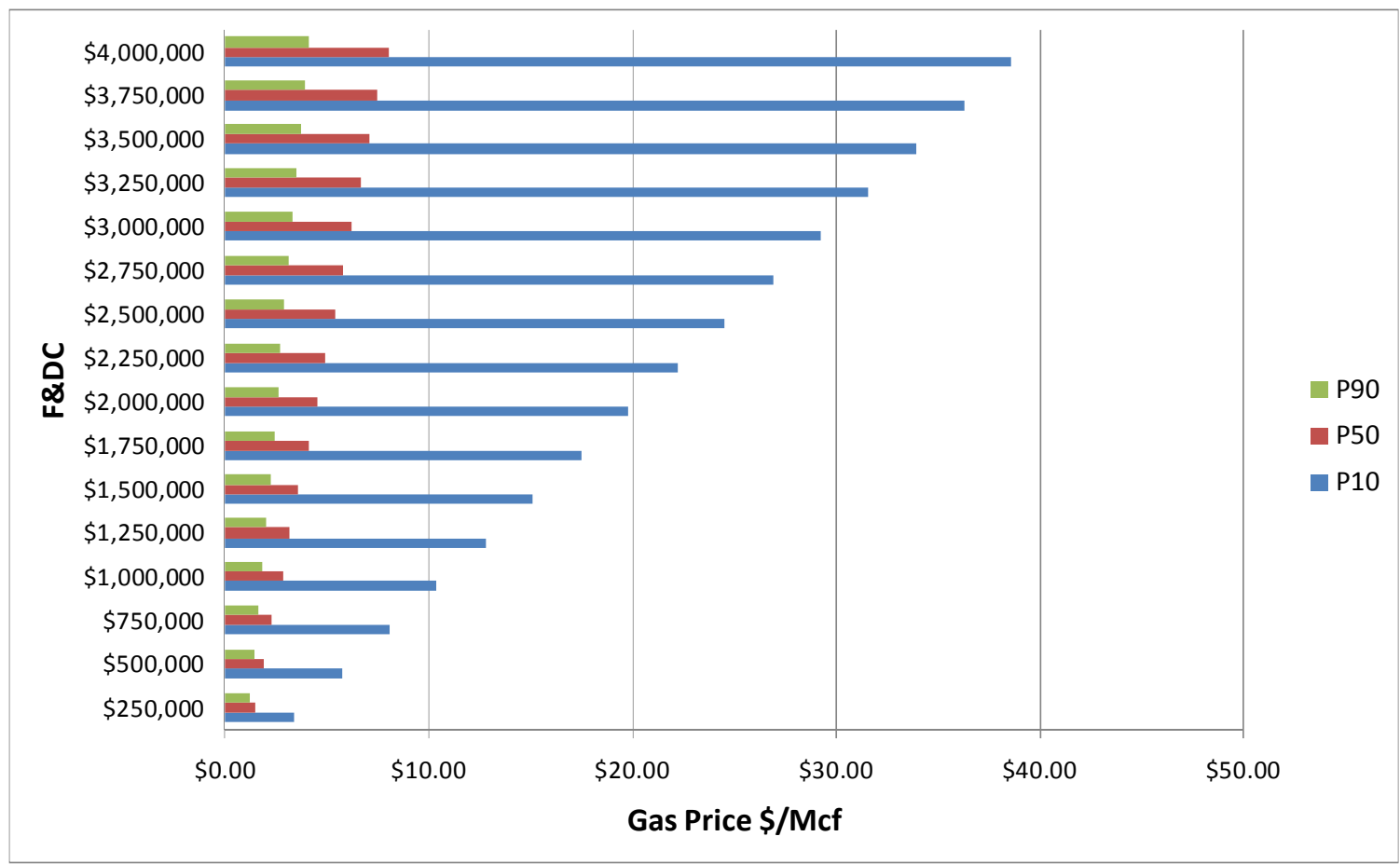

Fig. 7.1—Gas Prices Required to Meet Investment Hurdle at Different F\&D

Costs(Scenario I).

Tables 7.2, 7.3 and 7.4 show detailed economic analysis, converting the 25 -year stream of gas production to a stream of cash flow for the P10, P50, and P90 wells at Scenario I. 
Table 7.2-Detailed Economic Analysis for a P10 Well with an F\&DC of \$2 Million (Scenario I)

\begin{tabular}{|c|c|c|c|c|c|c|c|c|}
\hline & $\begin{array}{r}\text { Payout: } \\
\text { Payout Year: } \\
\text { Economic Limit Year: } \\
\$ 2,430,000\end{array}$ & $\begin{array}{r}4.39 \\
4 \\
26 \\
\$ 2,430,000\end{array}$ & $\$ 2,430,000$ & $\$ 2,430,000$ & $\begin{array}{l}225,000 \\
225,000\end{array}$ & & $\$ 684,721$ & $\$ 684,721$ \\
\hline $\begin{array}{c}\text { Time } \\
\text { (Years) }\end{array}$ & $\begin{array}{c}\text { Net } \\
\text { Cash Flow } \\
\text { (\$) }\end{array}$ & $\begin{array}{l}\text { Cum Net } \\
\text { Profit } \\
(\$) \\
\$ 0\end{array}$ & $\begin{array}{c}\text { Final } \\
\text { Net } \\
\text { Cash Flow } \\
\text { (\$) } \\
\$ 0\end{array}$ & $\begin{array}{c}\text { Final } \\
\text { Cum Net } \\
\text { Profit } \\
(\$) \\
\$ 0\end{array}$ & $\begin{array}{l}\text { Risked } \\
\text { Gross } \\
\text { Prod } \\
\text { (Mscf) }\end{array}$ & $\begin{array}{c}\text { Discount } \\
\text { Factor } \\
\text { (\%/yr) }\end{array}$ & $\begin{array}{l}\text { Disc. } \\
\text { Profit } \\
\qquad \begin{array}{l}(\$) \\
\end{array} \quad \$ 0\end{array}$ & $\begin{array}{l}\text { Cum } \\
\text { Disc. } \\
\text { Profit } \\
(\$) \\
\$ 0\end{array}$ \\
\hline 1 & $(\$ 1,800,000)$ & $(\$ 1,800,000)$ & $(\$ 1,800,000)$ & $(\$ 1,800,000)$ & 0 & 1 & $(\$ 1,800,000)$ & $(\$ 1,800,000)$ \\
\hline 2 & $\$ 932,316$ & $(\$ 867,684)$ & $\$ 932,316$ & $(\$ 867,684)$ & 49,591 & 0.909090909 & $\$ 847,560$ & $(\$ 952,440)$ \\
\hline 3 & $\$ 429,865$ & $(\$ 437,819)$ & $\$ 429,865$ & $(\$ 437,819)$ & 22,865 & 0.826446281 & $\$ 355,260$ & $(\$ 597,180)$ \\
\hline 4 & $\$ 330,459$ & $(\$ 107,360)$ & $\$ 330,459$ & $(\$ 107,360)$ & 17,578 & 0.751314801 & $\$ 248,279$ & $(\$ 348,901)$ \\
\hline 5 & $\$ 278,797$ & $\$ 171,437$ & $\$ 278,797$ & $\$ 171,437$ & 14,830 & 0.683013455 & $\$ 190,422$ & $(\$ 158,478)$ \\
\hline 6 & $\$ 245,725$ & $\$ 417,162$ & $\$ 245,725$ & $\$ 417,162$ & 13,070 & 0.620921323 & $\$ 152,576$ & $(\$ 5,903)$ \\
\hline 7 & $\$ 221,527$ & $\$ 638,690$ & $\$ 221,527$ & $\$ 638,690$ & 11,783 & 0.56447393 & $\$ 125,046$ & $\$ 119,144$ \\
\hline 8 & $\$ 200,446$ & $\$ 839,136$ & $\$ 200,446$ & $\$ 839,136$ & 10,662 & 0.513158118 & $\$ 102,861$ & $\$ 222,004$ \\
\hline 9 & $\$ 181,371$ & $\$ 1,020,507$ & $\$ 181,371$ & $\$ 1,020,507$ & 9,647 & 0.46650738 & $\$ 84,611$ & $\$ 306,615$ \\
\hline 10 & $\$ 164,111$ & $\$ 1,184,618$ & $\$ 164,111$ & $\$ 1,184,618$ & 8,729 & 0.424097618 & $\$ 69,599$ & $\$ 376,215$ \\
\hline 11 & $\$ 148,494$ & $\$ 1,333,113$ & $\$ 148,494$ & $\$ 1,333,113$ & 7,899 & 0.385543289 & $\$ 57,251$ & $\$ 433,466$ \\
\hline 12 & $\$ 134,363$ & $\$ 1,467,476$ & $\$ 134,363$ & $\$ 1,467,476$ & 7,147 & 0.350493899 & $\$ 47,093$ & $\$ 480,559$ \\
\hline 13 & $\$ 121,577$ & $\$ 1,589,053$ & $\$ 121,577$ & $\$ 1,589,053$ & 6,467 & 0.318630818 & $\$ 38,738$ & $\$ 519,297$ \\
\hline 14 & $\$ 110,007$ & $\$ 1,699,060$ & $\$ 110,007$ & $\$ 1,699,060$ & 5,851 & 0.28966438 & $\$ 31,865$ & $\$ 551,162$ \\
\hline 15 & $\$ 99,539$ & $\$ 1,798,598$ & $\$ 99,539$ & $\$ 1,798,598$ & 5,295 & 0.263331254 & $\$ 26,212$ & $\$ 577,374$ \\
\hline 16 & $\$ 90,066$ & $\$ 1,888,665$ & $\$ 90,066$ & $\$ 1,888,665$ & 4,791 & 0.239392049 & $\$ 21,561$ & $\$ 598,935$ \\
\hline 17 & $\$ 81,495$ & $\$ 1,970,160$ & $\$ 81,495$ & $\$ 1,970,160$ & 4,335 & 0.217629136 & $\$ 17,736$ & $\$ 616,671$ \\
\hline 18 & $\$ 73,740$ & $\$ 2,043,900$ & $\$ 73,740$ & $\$ 2,043,900$ & 3,922 & 0.197844669 & $\$ 14,589$ & $\$ 631,260$ \\
\hline 19 & $\$ 66,723$ & $\$ 2,110,623$ & $\$ 66,723$ & $\$ 2,110,623$ & 3,549 & 0.17985879 & $\$ 12,001$ & $\$ 643,261$ \\
\hline 20 & $\$ 60,373$ & $\$ 2,170,996$ & $\$ 60,373$ & $\$ 2,170,996$ & 3,211 & 0.163507991 & $\$ 9,872$ & $\$ 653,132$ \\
\hline 21 & $\$ 54,628$ & $\$ 2,225,624$ & $\$ 54,628$ & $\$ 2,225,624$ & 2,906 & 0.148643628 & $\$ 8,120$ & $\$ 661,252$ \\
\hline 22 & $\$ 49,429$ & $\$ 2,275,053$ & $\$ 49,429$ & $\$ 2,275,053$ & 2,629 & 0.135130571 & $\$ 6,679$ & $\$ 667,932$ \\
\hline 23 & $\$ 44,726$ & $\$ 2,319,779$ & $\$ 44,726$ & $\$ 2,319,779$ & 2,379 & 0.122845974 & $\$ 5,494$ & $\$ 673,426$ \\
\hline 24 & $\$ 40,469$ & $\$ 2,360,248$ & $\$ 40,469$ & $\$ 2,360,248$ & 2,153 & 0.111678158 & $\$ 4,520$ & $\$ 677,945$ \\
\hline 25 & $\$ 36,618$ & $\$ 2,396,866$ & $\$ 36,618$ & $\$ 2,396,866$ & 1,948 & 0.101525598 & $\$ 3,718$ & $\$ 681,663$ \\
\hline 26 & $\$ 33,134$ & $\$ 2,430,000$ & $\$ 33,134$ & $\$ 2,430,000$ & 1,762 & 0.092295998 & $\$ 3,058$ & $\$ 684,721$ \\
\hline
\end{tabular}


Table 7.3-Detailed Economic Analysis for a P50 Well with an F\&DC of \$2 Million (Scenario I)

\begin{tabular}{|c|c|c|c|c|c|c|c|c|}
\hline & $\begin{array}{r}\text { Payout: } \\
\text { Payout Year: } \\
\text { Economic Limit } \\
\text { Year: } \\
\$ 4,400,000\end{array}$ & $\begin{array}{r}4.55 \\
4 \\
\\
26 \\
\$ 4,400,000\end{array}$ & $\$ 4,400,000$ & $\$ 4,400,000$ & $\begin{array}{l}4,000,000 \\
4,000,000\end{array}$ & & $\$ 1,203,654$ & $\$ 1,203,654$ \\
\hline $\begin{array}{c}\text { Time } \\
\text { (Years) }\end{array}$ & $\begin{array}{c}\text { Net } \\
\text { Cash Flow } \\
\text { (\$) }\end{array}$ & $\begin{array}{c}\text { Cum Net } \\
\text { Profit } \\
(\$) \\
\$ 0 \\
\end{array}$ & $\begin{array}{c}\text { Final } \\
\text { Net } \\
\text { Cash Flow } \\
(\$) \\
\$ 0 \\
\end{array}$ & $\begin{array}{c}\text { Final } \\
\text { Cum Net } \\
\text { Profit } \\
(\$) \\
\$ 0 \\
\end{array}$ & $\begin{array}{l}\text { Risked } \\
\text { Gross } \\
\text { Prod } \\
\text { (Mscf) }\end{array}$ & $\begin{array}{c}\text { Discount } \\
\text { Factor } \\
\text { (\%/yr) }\end{array}$ & $\begin{array}{l}\text { Disc. } \\
\text { Profit } \\
\begin{array}{l}(\$) \\
\end{array} \quad \$ 0 \\
\end{array}$ & $\begin{array}{l}\text { Cum } \\
\text { Disc. } \\
\text { Profit } \\
(\$) \\
\$ 0 \\
\end{array}$ \\
\hline 1 & $(\$ 2,000,000)$ & $(\$ 2,000,000)$ & $(\$ 2,000,000)$ & $(\$ 2,000,000)$ & 0 & 1 & $(\$ 2,000,000)$ & $(\$ 2,000,000)$ \\
\hline 2 & $\$ 782,544$ & $(\$ 1,217,456)$ & $\$ 782,544$ & $(\$ 1,217,456)$ & 489,090 & 0.909090909 & $\$ 711,404$ & $(\$ 1,288,596)$ \\
\hline 3 & $\$ 548,577$ & $(\$ 668,879)$ & $\$ 548,577$ & $(\$ 668,879)$ & 342,861 & 0.826446281 & $\$ 453,369$ & $(\$ 835,227)$ \\
\hline 4 & $\$ 451,771$ & $(\$ 217,108)$ & $\$ 451,771$ & $(\$ 217,108)$ & 282,357 & 0.751314801 & $\$ 339,422$ & $(\$ 495,805)$ \\
\hline 5 & $\$ 394,511$ & $\$ 177,403$ & $\$ 394,511$ & $\$ 177,403$ & 246,569 & 0.683013455 & $\$ 269,456$ & $(\$ 226,349)$ \\
\hline 6 & $\$ 355,402$ & $\$ 532,805$ & $\$ 355,402$ & $\$ 532,805$ & 222,126 & 0.620921323 & $\$ 220,677$ & $(\$ 5,672)$ \\
\hline 7 & $\$ 326,449$ & $\$ 859,253$ & $\$ 326,449$ & $\$ 859,253$ & 204,030 & 0.56447393 & $\$ 184,272$ & $\$ 178,600$ \\
\hline 8 & $\$ 303,867$ & $\$ 1,163,121$ & $\$ 303,867$ & $\$ 1,163,121$ & 189,917 & 0.513158118 & $\$ 155,932$ & $\$ 334,532$ \\
\hline 9 & $\$ 285,436$ & $\$ 1,448,557$ & $\$ 285,436$ & $\$ 1,448,557$ & 178,398 & 0.46650738 & $\$ 133,158$ & $\$ 467,690$ \\
\hline 10 & $\$ 268,810$ & $\$ 1,717,367$ & $\$ 268,810$ & $\$ 1,717,367$ & 168,006 & 0.424097618 & $\$ 114,002$ & $\$ 581,692$ \\
\hline 11 & $\$ 253,156$ & $\$ 1,970,523$ & $\$ 253,156$ & $\$ 1,970,523$ & 158,222 & 0.385543289 & $\$ 97,603$ & $\$ 679,294$ \\
\hline 12 & $\$ 238,413$ & $\$ 2,208,937$ & $\$ 238,413$ & $\$ 2,208,937$ & 149,008 & 0.350493899 & $\$ 83,562$ & $\$ 762,857$ \\
\hline 13 & $\$ 224,529$ & $\$ 2,433,466$ & $\$ 224,529$ & $\$ 2,433,466$ & 140,331 & 0.318630818 & $\$ 71,542$ & $\$ 834,399$ \\
\hline 14 & $\$ 211,454$ & $\$ 2,644,920$ & $\$ 211,454$ & $\$ 2,644,920$ & 132,159 & 0.28966438 & $\$ 61,251$ & $\$ 895,649$ \\
\hline 15 & $\$ 199,140$ & $\$ 2,844,059$ & $\$ 199,140$ & $\$ 2,844,059$ & 124,462 & 0.263331254 & $\$ 52,440$ & $\$ 948,089$ \\
\hline 16 & $\$ 187,543$ & $\$ 3,031,602$ & $\$ 187,543$ & $\$ 3,031,602$ & 117,214 & 0.239392049 & $\$ 44,896$ & $\$ 992,985$ \\
\hline 17 & $\$ 176,621$ & $\$ 3,208,223$ & $\$ 176,621$ & $\$ 3,208,223$ & 110,388 & 0.217629136 & $\$ 38,438$ & $\$ 1,031,423$ \\
\hline 18 & $\$ 166,335$ & $\$ 3,374,558$ & $\$ 166,335$ & $\$ 3,374,558$ & 103,960 & 0.197844669 & $\$ 32,909$ & $\$ 1,064,332$ \\
\hline 19 & $\$ 156,649$ & $\$ 3,531,207$ & $\$ 156,649$ & $\$ 3,531,207$ & 97,905 & 0.17985879 & $\$ 28,175$ & $\$ 1,092,506$ \\
\hline 20 & $\$ 147,526$ & $\$ 3,678,733$ & $\$ 147,526$ & $\$ 3,678,733$ & 92,204 & 0.163507991 & $\$ 24,122$ & $\$ 1,116,628$ \\
\hline 21 & $\$ 138,935$ & $\$ 3,817,668$ & $\$ 138,935$ & $\$ 3,817,668$ & 86,834 & 0.148643628 & $\$ 20,652$ & $\$ 1,137,280$ \\
\hline 22 & $\$ 130,844$ & $\$ 3,948,512$ & $\$ 130,844$ & $\$ 3,948,512$ & 81,778 & 0.135130571 & $\$ 17,681$ & $\$ 1,154,961$ \\
\hline 23 & $\$ 123,224$ & $\$ 4,071,736$ & $\$ 123,224$ & $\$ 4,071,736$ & 77,015 & 0.122845974 & $\$ 15,138$ & $\$ 1,170,098$ \\
\hline 24 & $\$ 116,048$ & $\$ 4,187,784$ & $\$ 116,048$ & $\$ 4,187,784$ & 72,530 & 0.111678158 & $\$ 12,960$ & $\$ 1,183,059$ \\
\hline 25 & $\$ 109,290$ & $\$ 4,297,074$ & $\$ 109,290$ & $\$ 4,297,074$ & 68,306 & 0.101525598 & $\$ 11,096$ & $\$ 1,194,154$ \\
\hline 26 & $\$ 102,926$ & $\$ 4,400,000$ & $\$ 102,926$ & $\$ 4,400,000$ & 64,328 & 0.092295998 & $\$ 9,500$ & $\$ 1,203,654$ \\
\hline
\end{tabular}


Table 7.4-Detailed Economic Analysis for a P90 Well with an F\&DC of \$2 Million (Scenario I)

\begin{tabular}{|c|c|c|c|c|c|c|c|c|}
\hline & $\begin{array}{r}\text { Payout: } \\
\text { Payout Year: } \\
\text { Economic Limit } \\
\text { Year: } \\
\$ 3,250,000\end{array}$ & $\begin{array}{r}4.59 \\
4 \\
26 \\
\$ 3,250,000\end{array}$ & $\$ 3,250,000$ & $\$ 3,250,000$ & $\begin{array}{l}1,500,000 \\
1,500,000\end{array}$ & & $\$ 909,518$ & $\$ 909,518$ \\
\hline $\begin{array}{l}\text { Time } \\
\text { (Years) }\end{array}$ & $\begin{array}{l}\text { Net } \\
\text { Cash Flow } \\
\begin{array}{cc}(\$) & \\
& \$ 0 \\
\end{array}\end{array}$ & $\begin{array}{c}\text { Cum Net } \\
\text { Profit } \\
(\$) \\
\$ 0 \\
\end{array}$ & $\begin{array}{c}\text { Final } \\
\text { Net } \\
\text { Cash Flow } \\
(\$) \\
\$ 0 \\
\end{array}$ & $\begin{array}{l}\text { Final } \\
\text { Cum Net } \\
\text { Profit } \\
(\$) \\
\$ 0 \\
\end{array}$ & $\begin{array}{l}\text { Risked } \\
\text { Gross } \\
\text { Prod } \\
\text { (Mscf) } \\
\end{array}$ & $\begin{array}{l}\text { Discount } \\
\text { Factor } \\
\text { (\%/yr) }\end{array}$ & $\begin{array}{l}\text { Disc. } \\
\text { Profit } \\
\text { (\$) } \\
\\
\end{array}$ & $\begin{array}{l}\text { Cum } \\
\text { Disc. } \\
\text { Profit } \\
(\$) \\
\$ 0 \\
\end{array}$ \\
\hline 1 & $(\$ 2,000,000)$ & $(\$ 2,000,000)$ & $(\$ 2,000,000)$ & $(\$ 2,000,000)$ & 0 & 1 & $(\$ 2,000,000)$ & $(\$ 2,000,000)$ \\
\hline 2 & $\$ 859,999$ & $(\$ 1,140,001)$ & $\$ 859,999$ & $(\$ 1,140,001)$ & 245,714 & 0.909090909 & $\$ 781,817$ & $(\$ 1,218,183)$ \\
\hline 3 & $\$ 509,581$ & $(\$ 630,420)$ & $\$ 509,581$ & $(\$ 630,420)$ & 145,595 & 0.826446281 & $\$ 421,141$ & $(\$ 797,041)$ \\
\hline 4 & $\$ 415,785$ & $(\$ 214,635)$ & $\$ 415,785$ & $(\$ 214,635)$ & 118,796 & 0.751314801 & $\$ 312,385$ & $(\$ 484,656)$ \\
\hline 5 & $\$ 363,925$ & $\$ 149,290$ & $\$ 363,925$ & $\$ 149,290$ & 103,979 & 0.683013455 & $\$ 248,566$ & $(\$ 236,090)$ \\
\hline 6 & $\$ 328,042$ & $\$ 477,332$ & $\$ 328,042$ & $\$ 477,332$ & 93,726 & 0.620921323 & $\$ 203,688$ & $(\$ 32,402)$ \\
\hline 7 & $\$ 297,214$ & $\$ 774,546$ & $\$ 297,214$ & $\$ 774,546$ & 84,918 & 0.56447393 & $\$ 167,770$ & $\$ 135,368$ \\
\hline 8 & $\$ 269,610$ & $\$ 1,044,156$ & $\$ 269,610$ & $\$ 1,044,156$ & 77,031 & 0.513158118 & $\$ 138,352$ & $\$ 273,720$ \\
\hline 9 & $\$ 244,792$ & $\$ 1,288,949$ & $\$ 244,792$ & $\$ 1,288,949$ & 69,941 & 0.46650738 & $\$ 114,197$ & $\$ 387,918$ \\
\hline 10 & $\$ 222,341$ & $\$ 1,511,289$ & $\$ 222,341$ & $\$ 1,511,289$ & 63,526 & 0.424097618 & $\$ 94,294$ & $\$ 482,212$ \\
\hline 11 & $\$ 201,977$ & $\$ 1,713,266$ & $\$ 201,977$ & $\$ 1,713,266$ & 57,708 & 0.385543289 & $\$ 77,871$ & $\$ 560,083$ \\
\hline 12 & $\$ 183,504$ & $\$ 1,896,771$ & $\$ 183,504$ & $\$ 1,896,771$ & 52,430 & 0.350493899 & $\$ 64,317$ & $\$ 624,400$ \\
\hline 13 & $\$ 166,746$ & $\$ 2,063,517$ & $\$ 166,746$ & $\$ 2,063,517$ & 47,642 & 0.318630818 & $\$ 53,131$ & $\$ 677,530$ \\
\hline 14 & $\$ 151,542$ & $\$ 2,215,059$ & $\$ 151,542$ & $\$ 2,215,059$ & 43,298 & 0.28966438 & $\$ 43,896$ & $\$ 721,427$ \\
\hline 15 & $\$ 137,746$ & $\$ 2,352,805$ & $\$ 137,746$ & $\$ 2,352,805$ & 39,356 & 0.263331254 & $\$ 36,273$ & $\$ 757,700$ \\
\hline 16 & $\$ 125,226$ & $\$ 2,478,032$ & $\$ 125,226$ & $\$ 2,478,032$ & 35,779 & 0.239392049 & $\$ 29,978$ & $\$ 787,678$ \\
\hline 17 & $\$ 113,864$ & $\$ 2,591,896$ & $\$ 113,864$ & $\$ 2,591,896$ & 32,533 & 0.217629136 & $\$ 24,780$ & $\$ 812,458$ \\
\hline 18 & $\$ 103,550$ & $\$ 2,695,446$ & $\$ 103,550$ & $\$ 2,695,446$ & 29,586 & 0.197844669 & $\$ 20,487$ & $\$ 832,945$ \\
\hline 19 & $\$ 94,188$ & $\$ 2,789,634$ & $\$ 94,188$ & $\$ 2,789,634$ & 26,911 & 0.17985879 & $\$ 16,941$ & $\$ 849,885$ \\
\hline 20 & $\$ 85,688$ & $\$ 2,875,321$ & $\$ 85,688$ & $\$ 2,875,321$ & 24,482 & 0.163507991 & $\$ 14,011$ & $\$ 863,896$ \\
\hline 21 & $\$ 77,970$ & $\$ 2,953,291$ & $\$ 77,970$ & $\$ 2,953,291$ & 22,277 & 0.148643628 & $\$ 11,590$ & $\$ 875,486$ \\
\hline 22 & $\$ 70,960$ & $\$ 3,024,251$ & $\$ 70,960$ & $\$ 3,024,251$ & 20,274 & 0.135130571 & $\$ 9,589$ & $\$ 885,075$ \\
\hline 23 & $\$ 64,594$ & $\$ 3,088,846$ & $\$ 64,594$ & $\$ 3,088,846$ & 18,456 & 0.122845974 & $\$ 7,935$ & $\$ 893,010$ \\
\hline 24 & $\$ 58,812$ & $\$ 3,147,658$ & $\$ 58,812$ & $\$ 3,147,658$ & 16,803 & 0.111678158 & $\$ 6,568$ & $\$ 899,578$ \\
\hline 25 & $\$ 53,558$ & $\$ 3,201,216$ & $\$ 53,558$ & $\$ 3,201,216$ & 15,302 & 0.101525598 & $\$ 5,438$ & $\$ 905,015$ \\
\hline 26 & $\$ 48,784$ & $\$ 3,250,000$ & $\$ 48,784$ & $\$ 3,250,000$ & 13,938 & 0.092295998 & $\$ 4,503$ & $\$ 909,518$ \\
\hline
\end{tabular}




\subsubsection{Economics for $\mathrm{P}^{*}$ Well at Scenario I}

Based on the P10, P50, and P90 EUR values, a weighted EUR for P* Well was calculated as follows:

$$
\begin{aligned}
& \mathrm{P} * \text { Weighted EUR }=\mathrm{P} 10 \mathrm{EUR} * 16 \%+\mathrm{P} 50 \mathrm{EUR} * 68 \%+\mathrm{P} 90 \mathrm{EUR} * 16 \% \\
& \mathrm{P} * \text { Weighted EUR }=(0.250 * 0.16)+(1.5 * 0.68)+(4.0 * 0.16)=1.7 \mathrm{Bcf}
\end{aligned}
$$

The weighting factors have been selected so the values are approximately one standard deviation from the mean (Fig. 7.2).

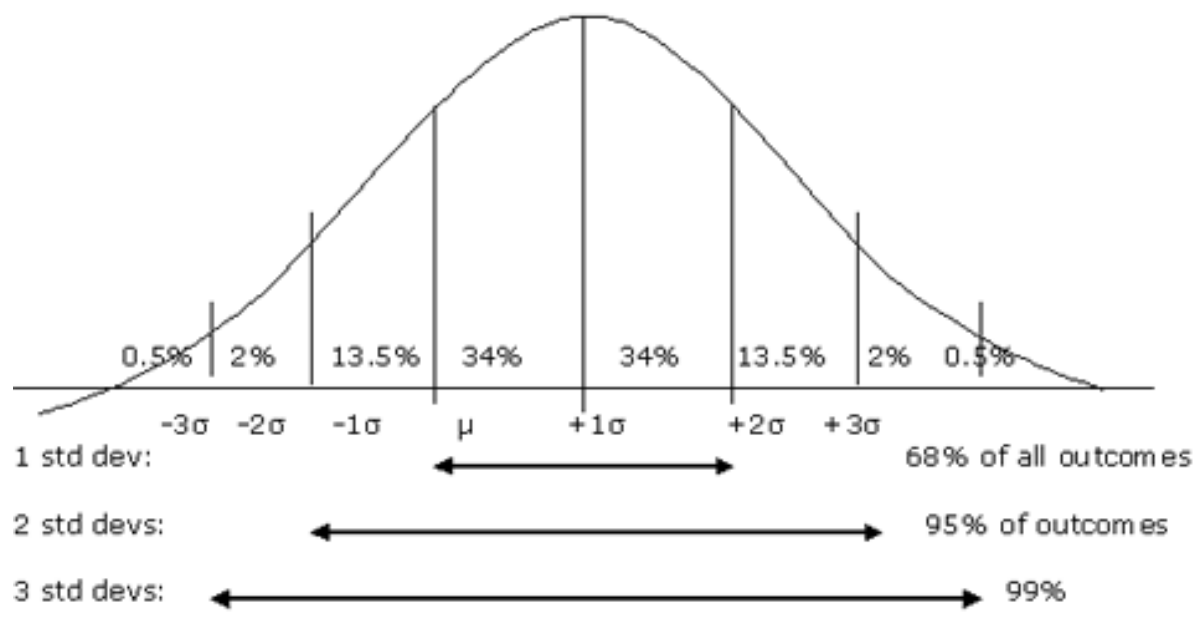

Fig. 7.2—Confidence Intervals for a Normal Distribution Curve.

Table 7.5 and Fig. 7.3 compare the required gas prices to meet the investment hurdle criteria for the P10, P50, P90, and P* Wells at different F\&DC costs. 
Table 7.5-Gas Prices to Meet Investment Hurdle at Different F\&DCs for a P10, P50, P90, and P* Well. (Scenario I)

\begin{tabular}{|c|c|c|c|c|c|c|c|}
\hline $\begin{array}{l}\text { EUR (Bcf) } \\
\text { P10 }\end{array}$ & 0.25 & $\begin{array}{c}\text { EUR } \\
\text { (Bscf) } \\
\text { P50 }\end{array}$ & 1.5 & $\begin{array}{c}\text { EUR (Bcf) } \\
\text { P90 }\end{array}$ & 4.00 & $\begin{array}{c}\text { EUR (Bcf) } \\
\qquad P^{*}\end{array}$ & 1.7 \\
\hline F\&DC & $\begin{array}{l}\text { Gas Price } \\
\text { per Mscf }\end{array}$ & F\&DC & $\begin{array}{c}\text { Gas Price } \\
\text { per Mcf }\end{array}$ & F\&DC & $\begin{array}{c}\text { Gas Price } \\
\text { per Mcf }\end{array}$ & F\&DC & $\begin{array}{c}\text { Gas Price } \\
\text { per Mcf }\end{array}$ \\
\hline$\$ 250,000$ & $\$ 3.40$ & $\$ 250,000$ & $\$ 1.50$ & $\$ 250,000$ & $\$ 1.20$ & $\$ 250,000$ & $\$ 1.50$ \\
\hline$\$ 500,000$ & $\$ 5.70$ & $\$ 500,000$ & $\$ 1.90$ & $\$ 500,000$ & $\$ 1.40$ & $\$ 500,000$ & $\$ 1.90$ \\
\hline$\$ 750,000$ & $\$ 8.10$ & $\$ 750,000$ & $\$ 2.30$ & $\$ 750,000$ & $\$ 1.60$ & $\$ 750,000$ & $\$ 2.30$ \\
\hline$\$ 1,000,000$ & $\$ 10.40$ & $\$ 1,000,000$ & $\$ 2.80$ & $\$ 1,000,000$ & $\$ 1.80$ & $\$ 1,000,000$ & $\$ 2.70$ \\
\hline$\$ 1,250,000$ & $\$ 12.80$ & $\$ 1,250,000$ & $\$ 3.20$ & $\$ 1,250,000$ & $\$ 2.00$ & $\$ 1,250,000$ & $\$ 3.10$ \\
\hline$\$ 1,500,000$ & $\$ 15.10$ & $\$ 1,500,000$ & $\$ 3.60$ & $\$ 1,500,000$ & $\$ 2.20$ & $\$ 1,500,000$ & $\$ 3.50$ \\
\hline$\$ 1,750,000$ & $\$ 17.50$ & $\$ 1,750,000$ & $\$ 4.10$ & $\$ 1,750,000$ & $\$ 2.40$ & $\$ 1,750,000$ & $\$ 3.90$ \\
\hline$\$ 2,000,000$ & $\$ 19.80$ & $\$ 2,000,000$ & $\$ 4.50$ & $\$ 2,000,000$ & $\$ 2.60$ & $\$ 2,000,000$ & $\$ 4.30$ \\
\hline$\$ 2,250,000$ & $\$ 22.20$ & $\$ 2,250,000$ & $\$ 4.90$ & $\$ 2,250,000$ & $\$ 2.70$ & $\$ 2,250,000$ & $\$ 4.70$ \\
\hline$\$ 2,500,000$ & $\$ 24.50$ & $\$ 2,500,000$ & $\$ 5.40$ & $\$ 2,500,000$ & $\$ 2.90$ & $\$ 2,500,000$ & $\$ 5.10$ \\
\hline$\$ 2,750,000$ & $\$ 26.90$ & $\$ 2,750,000$ & $\$ 5.80$ & $\$ 2,750,000$ & $\$ 3.10$ & $\$ 2,750,000$ & $\$ 5.50$ \\
\hline$\$ 3,000,000$ & $\$ 29.20$ & $\$ 3,000,000$ & $\$ 6.20$ & $\$ 3,000,000$ & $\$ 3.30$ & $\$ 3,000,000$ & $\$ 5.90$ \\
\hline$\$ 3,250,000$ & $\$ 31.60$ & $\$ 3,250,000$ & $\$ 6.70$ & $\$ 3,250,000$ & $\$ 3.50$ & $\$ 3,250,000$ & $\$ 6.30$ \\
\hline$\$ 3,500,000$ & $\$ 33.90$ & $\$ 3,500,000$ & $\$ 7.10$ & $\$ 3,500,000$ & $\$ 3.70$ & $\$ 3,500,000$ & $\$ 6.70$ \\
\hline$\$ 3,750,000$ & $\$ 36.30$ & $\$ 3,750,000$ & $\$ 7.50$ & $\$ 3,750,000$ & $\$ 3.90$ & $\$ 3,750,000$ & $\$ 7.10$ \\
\hline$\$ 4,000,000$ & $\$ 38.60$ & $\$ 4,000,000$ & $\$ 8.00$ & $\$ 4,000,000$ & $\$ 4.10$ & $\$ 4,000,000$ & $\$ 7.50$ \\
\hline
\end{tabular}




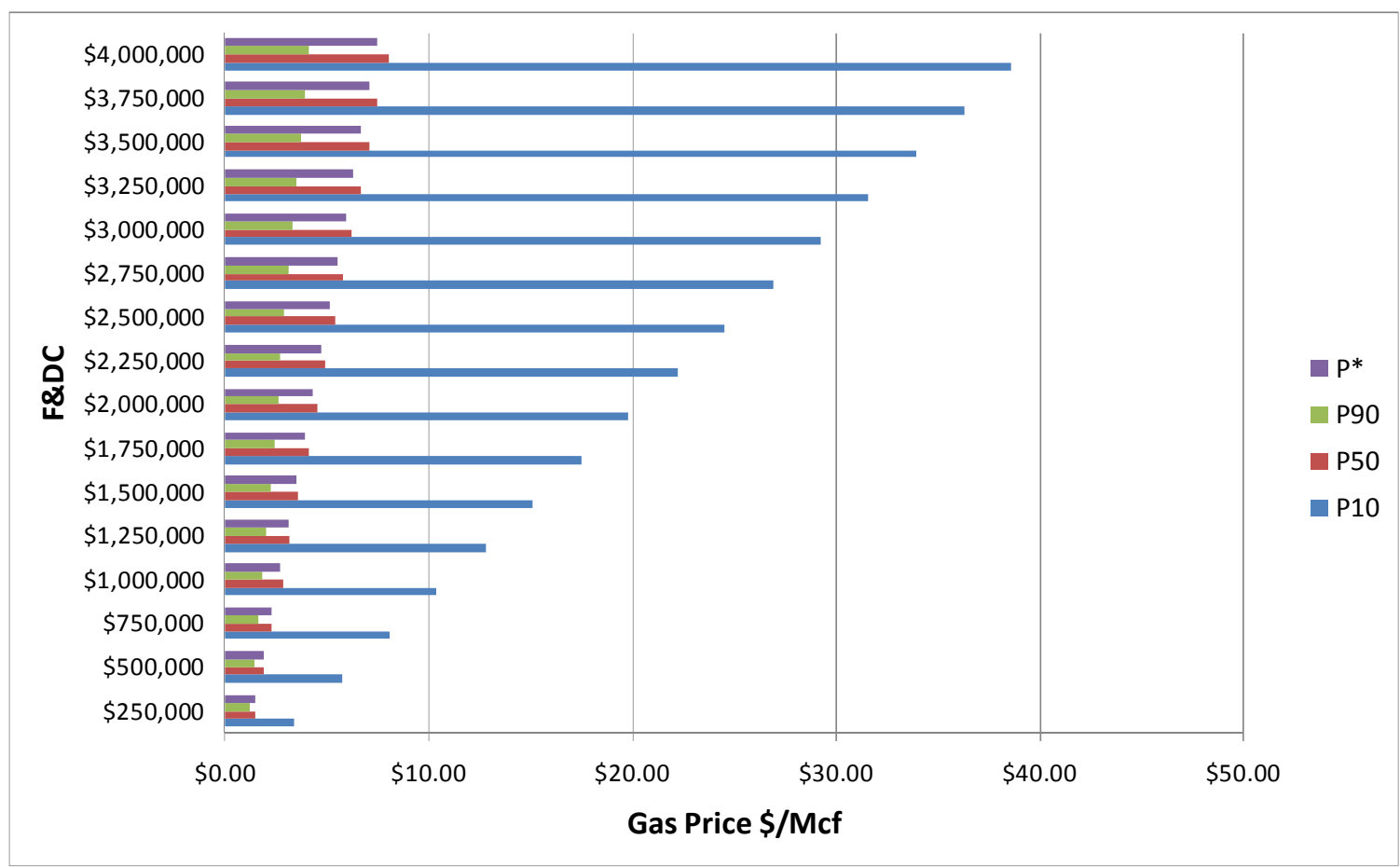

Fig. 7.3-Gas Prices to Meet Investment Hurdle at Different F\&DCs a P10, P50, P90, and $\mathrm{P} *$ Well(Scenario I).

Table 7.6 shows detailed economic analysis, converting the 25-year stream of gas production to a stream of cash flows for the $\mathrm{P}^{*}$ well at Scenario I. 
Table 7.6-Detailed Economic Analysis for a $\mathrm{P} *$ Well with an F\&DC of \$2 Million (Scenario I)

\begin{tabular}{|c|c|c|c|c|c|c|c|c|}
\hline & $\begin{array}{r}\text { Payout: } \\
\text { Payout Year: } \\
\text { Economic Limit } \\
\text { Year: } \\
\$ 3,610,000\end{array}$ & $\begin{array}{r}4.58 \\
4 \\
26 \\
26 \\
\$ 3,610,000\end{array}$ & $\$ 3,610,000$ & $\$ 3,610,000$ & $\begin{array}{l}1,700,000 \\
1,700,000\end{array}$ & & $\$ 999,848$ & $\$ 999,848$ \\
\hline $\begin{array}{l}\text { Time } \\
\text { (Years) }\end{array}$ & $\begin{array}{l}\text { Net } \\
\text { Cash Flow } \\
\begin{array}{ll}(\$) & \\
& \$ 0 \\
\end{array}\end{array}$ & $\begin{array}{c}\text { Cum Net } \\
\text { Profit } \\
(\$) \\
\$ 0 \\
\end{array}$ & $\begin{array}{c}\text { Final } \\
\text { Net } \\
\text { Cash Flow } \\
(\$) \\
\$ 0 \\
\end{array}$ & $\begin{array}{l}\text { Final } \\
\text { Cum Net } \\
\text { Profit } \\
(\$) \\
\$ 0 \\
\end{array}$ & $\begin{array}{l}\text { Risked } \\
\text { Gross } \\
\text { Prod } \\
\text { (Mscf) } \\
\end{array}$ & $\begin{array}{c}\text { Discount } \\
\text { Factor } \\
\text { (\%/yr) }\end{array}$ & $\begin{array}{l}\text { Disc. } \\
\text { Profit } \\
\begin{array}{l}(\$) \\
\end{array} \quad \$ 0 \\
\end{array}$ & $\begin{array}{l}\text { Cum } \\
\text { Disc. } \\
\text { Profit } \\
(\$) \\
\$ 0 \\
\end{array}$ \\
\hline 1 & $(\$ 2,000,000)$ & $(\$ 2,000,000)$ & $(\$ 2,000,000)$ & $(\$ 2,000,000)$ & 0 & 1 & $(\$ 2,000,000)$ & $(\$ 2,000,000)$ \\
\hline 2 & $\$ 838,123$ & $(\$ 1,161,877)$ & $\$ 838,123$ & $(\$ 1,161,877)$ & 253,977 & 0.909090909 & $\$ 761,930$ & $(\$ 1,238,070)$ \\
\hline 3 & $\$ 521,121$ & $(\$ 640,756)$ & $\$ 521,121$ & $(\$ 640,756)$ & 157,915 & 0.826446281 & $\$ 430,679$ & $(\$ 807,392)$ \\
\hline 4 & $\$ 425,997$ & $(\$ 214,759)$ & $\$ 425,997$ & $(\$ 214,759)$ & 129,090 & 0.751314801 & $\$ 320,058$ & $(\$ 487,334)$ \\
\hline 5 & $\$ 372,265$ & $\$ 157,505$ & $\$ 372,265$ & $\$ 157,505$ & 112,807 & 0.683013455 & $\$ 254,262$ & $(\$ 233,072)$ \\
\hline 6 & $\$ 335,331$ & $\$ 492,837$ & $\$ 335,331$ & $\$ 492,837$ & 101,615 & 0.620921323 & $\$ 208,214$ & $(\$ 24,858)$ \\
\hline 7 & $\$ 305,253$ & $\$ 798,089$ & $\$ 305,253$ & $\$ 798,089$ & 92,501 & 0.56447393 & $\$ 172,307$ & $\$ 147,450$ \\
\hline 8 & $\$ 279,440$ & $\$ 1,077,529$ & $\$ 279,440$ & $\$ 1,077,529$ & 84,679 & 0.513158118 & $\$ 143,397$ & $\$ 290,846$ \\
\hline 9 & $\$ 256,846$ & $\$ 1,334,375$ & $\$ 256,846$ & $\$ 1,334,375$ & 77,832 & 0.46650738 & $\$ 119,820$ & $\$ 410,667$ \\
\hline 10 & $\$ 236,422$ & $\$ 1,570,797$ & $\$ 236,422$ & $\$ 1,570,797$ & 71,643 & 0.424097618 & $\$ 100,266$ & $\$ 510,933$ \\
\hline 11 & $\$ 217,708$ & $\$ 1,788,505$ & $\$ 217,708$ & $\$ 1,788,505$ & 65,972 & 0.385543289 & $\$ 83,936$ & $\$ 594,869$ \\
\hline 12 & $\$ 200,555$ & $\$ 1,989,060$ & $\$ 200,555$ & $\$ 1,989,060$ & 60,774 & 0.350493899 & $\$ 70,293$ & $\$ 665,162$ \\
\hline 13 & $\$ 184,827$ & $\$ 2,173,887$ & $\$ 184,827$ & $\$ 2,173,887$ & 56,008 & 0.318630818 & $\$ 58,892$ & $\$ 724,054$ \\
\hline 14 & $\$ 170,400$ & $\$ 2,344,287$ & $\$ 170,400$ & $\$ 2,344,287$ & 51,636 & 0.28966438 & $\$ 49,359$ & $\$ 773,412$ \\
\hline 15 & $\$ 157,162$ & $\$ 2,501,449$ & $\$ 157,162$ & $\$ 2,501,449$ & 47,625 & 0.263331254 & $\$ 41,386$ & $\$ 814,798$ \\
\hline 16 & $\$ 145,010$ & $\$ 2,646,459$ & $\$ 145,010$ & $\$ 2,646,459$ & 43,942 & 0.239392049 & $\$ 34,714$ & $\$ 849,512$ \\
\hline 17 & $\$ 133,851$ & $\$ 2,780,310$ & $\$ 133,851$ & $\$ 2,780,310$ & 40,561 & 0.217629136 & $\$ 29,130$ & $\$ 878,642$ \\
\hline 18 & $\$ 123,601$ & $\$ 2,903,911$ & $\$ 123,601$ & $\$ 2,903,911$ & 37,455 & 0.197844669 & $\$ 24,454$ & $\$ 903,096$ \\
\hline 19 & $\$ 114,181$ & $\$ 3,018,092$ & $\$ 114,181$ & $\$ 3,018,092$ & 34,600 & 0.17985879 & $\$ 20,536$ & $\$ 923,632$ \\
\hline 20 & $\$ 105,521$ & $\$ 3,123,613$ & $\$ 105,521$ & $\$ 3,123,613$ & 31,976 & 0.163507991 & $\$ 17,253$ & $\$ 940,886$ \\
\hline 21 & $\$ 97,556$ & $\$ 3,221,169$ & $\$ 97,556$ & $\$ 3,221,169$ & 29,563 & 0.148643628 & $\$ 14,501$ & $\$ 955,387$ \\
\hline 22 & $\$ 90,229$ & $\$ 3,311,398$ & $\$ 90,229$ & $\$ 3,311,398$ & 27,342 & 0.135130571 & $\$ 12,193$ & $\$ 967,580$ \\
\hline 23 & $\$ 83,485$ & $\$ 3,394,883$ & $\$ 83,485$ & $\$ 3,394,883$ & 25,299 & 0.122845974 & $\$ 10,256$ & $\$ 977,835$ \\
\hline 24 & $\$ 77,276$ & $\$ 3,472,159$ & $\$ 77,276$ & $\$ 3,472,159$ & 23,417 & 0.111678158 & $\$ 8,630$ & $\$ 986,465$ \\
\hline 25 & $\$ 71,556$ & $\$ 3,543,715$ & $\$ 71,556$ & $\$ 3,543,715$ & 21,684 & 0.101525598 & $\$ 7,265$ & $\$ 993,730$ \\
\hline 26 & $\$ 66,285$ & $\$ 3,610,000$ & $\$ 66,285$ & $\$ 3,610,000$ & 20,086 & 0.092295998 & $\$ 6,118$ & $\$ 999,848$ \\
\hline
\end{tabular}


Using the assumptions detailed at the beginning of the section, Table $\mathbf{7 . 7}$ compares the required gas prices to meet the investment hurdle criteria for P10 Well, P50 Well, P90 Well, and P*Well, and the resulting ROR and Payout.

Table 7.7—ROR and Payout Periods for P10, P50, P90, and P* with a \$2 Million F\&DC (Scenario I)

\begin{tabular}{|c|c|c|c|c|}
\hline & P10 Well & P50 Well & P90 Well & P Well $^{*}$ \\
\hline EUR (Bcf) & .250 & $1.5 \mathrm{Bcf}$ & $4.0 \mathrm{Bcf}$ & $1.7 \mathrm{Bcf}$ \\
\hline Gas Price (\$/Mcf) & 21.0 & 4.70 & 2.70 & 4.50 \\
\hline Payout Period (Years) & 4.4 & 4.6 & 4.6 & 4.6 \\
\hline ROR (\%) & 20 & 20 & 22 & 21 \\
\hline
\end{tabular}

\subsection{Well-Level Economics: Scenario II}

The economic analysis in this section will be performed at the following assumptions:

Assumptions for Scenario II

- F\&DC of \$2 million;

- $25 \%$ royalty burden;

- $\quad 90 \%$ probability of success;

- $\quad 0 \%$ escalation of gas prices and costs;

- $\quad 6 \%$ fuel and shrinkage;

- $\quad$ LOE of \$1.0/Mcf; and

- $\quad 10 \%$ annual discount rate. 
The well life used for the analysis is 25 years with a $10 \%$ annual discount rate. Note that the EURs are lower than the values in

. This occurs because of the assumption that the probability of success is $90 \%$. In addition, the $25 \%$ royalty burden also affects the economic analysis as follows:

EUR at $90 \%$ Probability of Success $=$ EUR $* 0.9$

Net Production $=$ Gross Production $*(1-$ Royalty Burden $)$

\subsubsection{Economics for P10, P50, P90, and P* Wells at Scenario II}

Table 7.8 and Fig. 7.4 compare the required gas prices to meet the investment hurdle criteria for the P10, P50, P90, and P* Wells at different F\&D costs (Scenario II). Table 7.9, 7.10, 7.11, and 7.12 show detailed economic analysis, converting the 25-year stream of gas production to a stream of cash flows for the P10, P50, P90, and $\mathrm{P}^{*}$ wells (Scenario II). 
Table 7.8-Gas Prices to Meet the Investment Hurdle at Different F\&DCs for a P10, P50, P90, and P* Well (Scenario II)

\begin{tabular}{|c|c|c|c|c|c|c|c|}
\hline $\begin{array}{c}\text { EUR (Bcf) } \\
\text { P10 }\end{array}$ & 0.23 & $\begin{array}{c}\text { EUR (Bcf) } \\
\text { P50 }\end{array}$ & 1.35 & $\begin{array}{c}\text { EUR (Bcf) } \\
\text { P9o }\end{array}$ & 3.60 & $\begin{array}{c}\text { EUR (Bcf) } \\
\qquad \mathbf{P}^{*}\end{array}$ & 1.53 \\
\hline F\&DC & $\begin{array}{c}\text { Gas Price } \\
\text { per Mcf }\end{array}$ & F\&DC & $\begin{array}{c}\text { Gas Price } \\
\text { per Mcf }\end{array}$ & F\&DC & $\begin{array}{c}\text { Gas Price } \\
\text { per Mcf }\end{array}$ & F\&DC & $\begin{array}{c}\text { Gas Price } \\
\text { Mscf }\end{array}$ \\
\hline$\$ 250,000$ & $\$ 4.80$ & $\$ 250,000$ & $\$ 1.70$ & $\$ 250,000$ & $\$ 1.30$ & $\$ 250,000$ & $\$ 1.70$ \\
\hline$\$ 500,000$ & $\$ 8.50$ & $\$ 500,000$ & $\$ 2.40$ & $\$ 500,000$ & $\$ 1.60$ & $\$ 500,000$ & $\$ 2.30$ \\
\hline$\$ 750,000$ & $\$ 12.20$ & $\$ 750,000$ & $\$ 3.10$ & $\$ 750,000$ & $\$ 1.90$ & $\$ 750,000$ & $\$ 2.90$ \\
\hline$\$ 1,000,000$ & $\$ 15.90$ & $\$ 1,000,000$ & $\$ 3.80$ & $\$ 1,000,000$ & $\$ 2.20$ & $\$ 1,000,000$ & $\$ 3.60$ \\
\hline$\$ 1,250,000$ & $\$ 19.60$ & $\$ 1,250,000$ & $\$ 4.50$ & $\$ 1,250,000$ & $\$ 2.50$ & $\$ 1,250,000$ & $\$ 4.20$ \\
\hline$\$ 1,500,000$ & $\$ 23.30$ & $\$ 1,500,000$ & $\$ 5.10$ & $\$ 1,500,000$ & $\$ 2.80$ & $\$ 1,500,000$ & $\$ 4.80$ \\
\hline$\$ 1,750,000$ & $\$ 27.00$ & $\$ 1,750,000$ & $\$ 5.80$ & $\$ 1,750,000$ & $\$ 3.10$ & $\$ 1,750,000$ & $\$ 5.50$ \\
\hline$\$ 2,000,000$ & $\$ 30.70$ & $\$ 2,000,000$ & $\$ 6.50$ & $\$ 2,000,000$ & $\$ 3.40$ & $\$ 2,000,000$ & $\$ 6.10$ \\
\hline$\$ 2,250,000$ & $\$ 34.40$ & $\$ 2,250,000$ & $\$ 7.20$ & $\$ 2,250,000$ & $\$ 3.70$ & $\$ 2,250,000$ & $\$ 6.70$ \\
\hline$\$ 2,500,000$ & $\$ 38.10$ & $\$ 2,500,000$ & $\$ 7.90$ & $\$ 2,500,000$ & $\$ 4.00$ & $\$ 2,500,000$ & $\$ 7.40$ \\
\hline$\$ 2,750,000$ & $\$ 41.80$ & $\$ 2,750,000$ & $\$ 8.50$ & $\$ 2,750,000$ & $\$ 4.30$ & $\$ 2,750,000$ & $\$ 8.00$ \\
\hline$\$ 3,000,000$ & $\$ 45.50$ & $\$ 3,000,000$ & $\$ 9.20$ & $\$ 3,000,000$ & $\$ 4.60$ & $\$ 3,000,000$ & $\$ 8.60$ \\
\hline$\$ 3,250,000$ & $\$ 49.20$ & $\$ 3,250,000$ & $\$ 9.90$ & $\$ 3,250,000$ & $\$ 4.90$ & $\$ 3,250,000$ & $\$ 9.30$ \\
\hline$\$ 3,500,000$ & $\$ 52.90$ & $\$ 3,500,000$ & $\$ 10.60$ & $\$ 3,500,000$ & $\$ 5.20$ & $\$ 3,500,000$ & $\$ 9.90$ \\
\hline$\$ 3,750,000$ & $\$ 56.60$ & $\$ 3,750,000$ & $\$ 11.30$ & $\$ 3,750,000$ & $\$ 5.50$ & $\$ 3,750,000$ & $\$ 10.50$ \\
\hline$\$ 4,000,000$ & $\$ 60.30$ & $\$ 4,000,000$ & $\$ 11.90$ & $\$ 4,000,000$ & $\$ 5.80$ & $\$ 4,000,000$ & $\$ 11.20$ \\
\hline
\end{tabular}




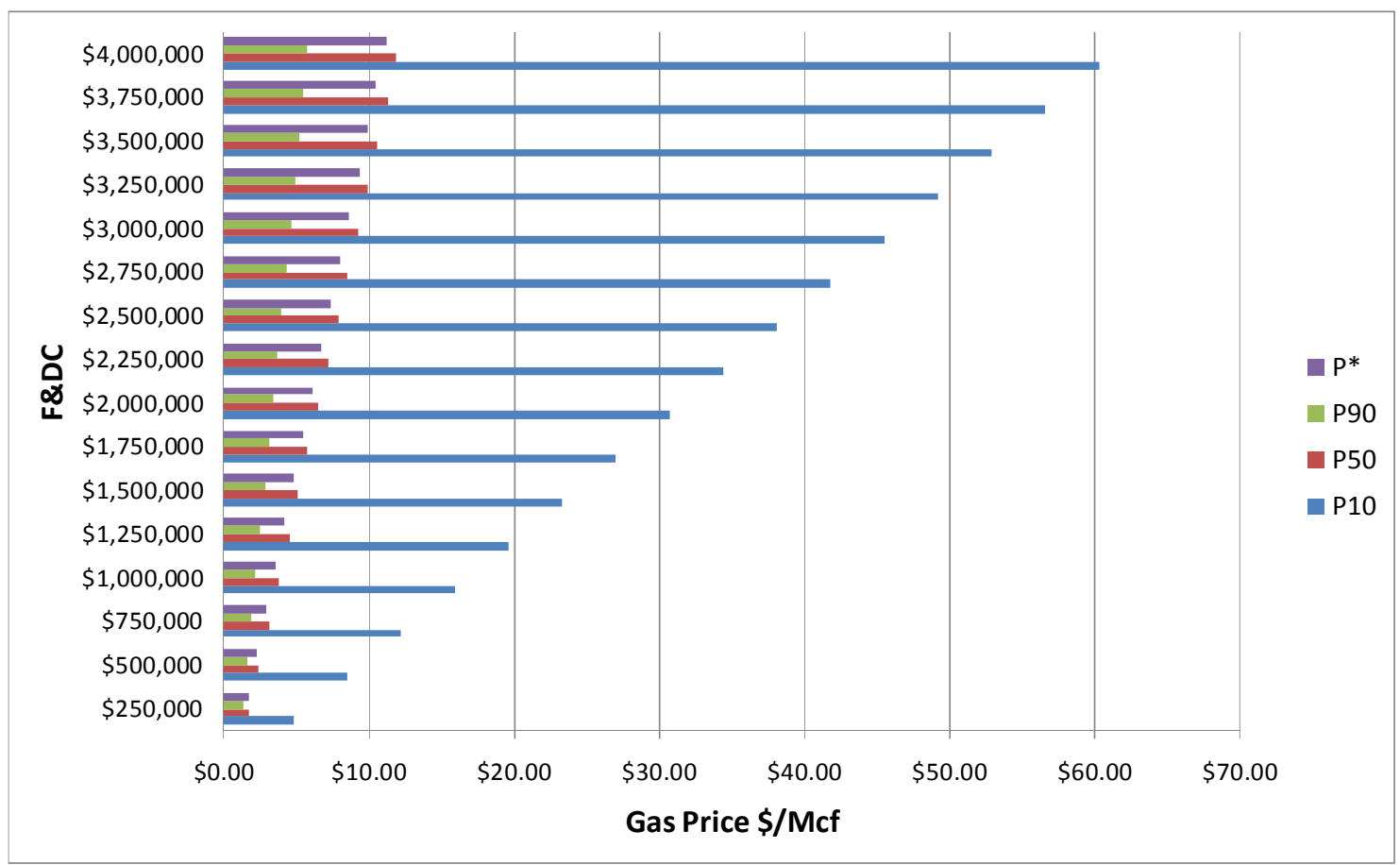

Fig. 7.4-Gas Prices to Meet the Investment Hurdle at Different F\&D Costs a P10, P50, P90, and P* Well (Scenario II). 
Table 7.9-Detailed Economic Analysis for a P10 Well with an F\&DC of \$2 Million. (Scenario II)

\begin{tabular}{|c|c|c|c|c|c|c|c|c|}
\hline & $\begin{array}{c}\text { Payout: } \\
\text { Payout Year: } \\
\text { Economic Limit } \\
\text { Year: } \\
\$ 2,440,046\end{array}$ & $\begin{array}{c}4.37 \\
4 \\
26 \\
\$ 2,440,046\end{array}$ & $\$ 2,440,046$ & $\$ 2,440,046$ & $\begin{array}{l}202,500 \\
202,500\end{array}$ & & $\$ 690,622$ & $\$ 690,622$ \\
\hline $\begin{array}{c}\text { Time } \\
\text { (Years) }\end{array}$ & $\begin{array}{c}\text { Net } \\
\text { Cash Flow } \\
(\$) \\
\$ 0 \\
\end{array}$ & $\begin{array}{c}\text { Cum Net } \\
\text { Profit } \\
(\$) \\
\$ 0\end{array}$ & $\begin{array}{c}\text { Final } \\
\text { Net } \\
\text { Cash Flow } \\
(\$) \\
\$ 0 \\
\end{array}$ & $\begin{array}{c}\text { Final } \\
\text { Cum Net } \\
\text { Profit } \\
(\$) \\
\$ 0 \\
\end{array}$ & $\begin{array}{c}\text { Risked } \\
\text { Gross } \\
\text { Prod } \\
\text { (Mscf) } \\
\end{array}$ & $\begin{array}{l}\text { Discount } \\
\text { Factor } \\
\text { (\%/yr) }\end{array}$ & $\begin{array}{c}\text { Disc. } \\
\text { Profit } \\
(\$) \\
\$ 0 \\
\end{array}$ & $\begin{array}{l}\text { Cum } \\
\text { Disc. } \\
\text { Profit } \\
(\$) \\
\$ 0 \\
\end{array}$ \\
\hline 1 & $(\$ 1,800,000)$ & $(\$ 1,800,000)$ & $(\$ 1,800,000)$ & $(\$ 1,800,000)$ & 0 & 1 & $(\$ 1,800,000)$ & $(\$ 1,800,000)$ \\
\hline 2 & $\$ 934,530$ & $(\$ 865,470)$ & $\$ 934,530$ & $(\$ 865,470)$ & 44,632 & 0.909090909 & $\$ 849,573$ & $(\$ 950,427)$ \\
\hline 3 & $\$ 430,886$ & $(\$ 434,584)$ & $\$ 430,886$ & $(\$ 434,584)$ & 20,579 & 0.826446281 & $\$ 356,104$ & $(\$ 594,323)$ \\
\hline 4 & $\$ 331,244$ & $(\$ 103,340)$ & $\$ 331,244$ & $(\$ 103,340)$ & 15,820 & 0.751314801 & $\$ 248,868$ & $(\$ 345,454)$ \\
\hline 5 & $\$ 279,459$ & $\$ 176,120$ & $\$ 279,459$ & $\$ 176,120$ & 13,347 & 0.683013455 & $\$ 190,875$ & $(\$ 154,580)$ \\
\hline 6 & $\$ 246,309$ & $\$ 422,428$ & $\$ 246,309$ & $\$ 422,428$ & 11,763 & 0.620921323 & $\$ 152,938$ & $(\$ 1,642)$ \\
\hline 7 & $\$ 222,053$ & $\$ 644,482$ & $\$ 222,053$ & $\$ 644,482$ & 10,605 & 0.56447393 & $\$ 125,343$ & $\$ 123,702$ \\
\hline 8 & $\$ 200,922$ & $\$ 845,404$ & $\$ 200,922$ & $\$ 845,404$ & 9,596 & 0.513158118 & $\$ 103,105$ & $\$ 226,807$ \\
\hline 9 & $\$ 181,802$ & $\$ 1,027,206$ & $\$ 181,802$ & $\$ 1,027,206$ & 8,683 & 0.46650738 & $\$ 84,812$ & $\$ 311,619$ \\
\hline 10 & $\$ 164,501$ & $\$ 1,191,707$ & $\$ 164,501$ & $\$ 1,191,707$ & 7,856 & 0.424097618 & $\$ 69,765$ & $\$ 381,383$ \\
\hline 11 & $\$ 148,847$ & $\$ 1,340,554$ & $\$ 148,847$ & $\$ 1,340,554$ & 7,109 & 0.385543289 & $\$ 57,387$ & $\$ 438,770$ \\
\hline 12 & $\$ 134,682$ & $\$ 1,475,236$ & $\$ 134,682$ & $\$ 1,475,236$ & 6,432 & 0.350493899 & $\$ 47,205$ & $\$ 485,975$ \\
\hline 13 & $\$ 121,865$ & $\$ 1,597,102$ & $\$ 121,865$ & $\$ 1,597,102$ & 5,820 & 0.318630818 & $\$ 38,830$ & $\$ 524,805$ \\
\hline 14 & $\$ 110,268$ & $\$ 1,707,370$ & $\$ 110,268$ & $\$ 1,707,370$ & 5,266 & 0.28966438 & $\$ 31,941$ & $\$ 556,746$ \\
\hline 15 & $\$ 99,775$ & $\$ 1,807,145$ & $\$ 99,775$ & $\$ 1,807,145$ & 4,765 & 0.263331254 & $\$ 26,274$ & $\$ 583,020$ \\
\hline 16 & $\$ 90,280$ & $\$ 1,897,425$ & $\$ 90,280$ & $\$ 1,897,425$ & 4,312 & 0.239392049 & $\$ 21,612$ & $\$ 604,632$ \\
\hline 17 & $\$ 81,689$ & $\$ 1,979,114$ & $\$ 81,689$ & $\$ 1,979,114$ & 3,901 & 0.217629136 & $\$ 17,778$ & $\$ 622,410$ \\
\hline 18 & $\$ 73,915$ & $\$ 2,053,029$ & $\$ 73,915$ & $\$ 2,053,029$ & 3,530 & 0.197844669 & $\$ 14,624$ & $\$ 637,034$ \\
\hline 19 & $\$ 66,881$ & $\$ 2,119,910$ & $\$ 66,881$ & $\$ 2,119,910$ & 3,194 & 0.17985879 & $\$ 12,029$ & $\$ 649,063$ \\
\hline 20 & $\$ 60,517$ & $\$ 2,180,427$ & $\$ 60,517$ & $\$ 2,180,427$ & 2,890 & 0.163507991 & $\$ 9,895$ & $\$ 658,958$ \\
\hline 21 & $\$ 54,758$ & $\$ 2,235,185$ & $\$ 54,758$ & $\$ 2,235,185$ & 2,615 & 0.148643628 & $\$ 8,139$ & $\$ 667,098$ \\
\hline 22 & $\$ 49,547$ & $\$ 2,284,732$ & $\$ 49,547$ & $\$ 2,284,732$ & 2,366 & 0.135130571 & $\$ 6,695$ & $\$ 673,793$ \\
\hline 23 & $\$ 44,832$ & $\$ 2,329,563$ & $\$ 44,832$ & $\$ 2,329,563$ & 2,141 & 0.122845974 & $\$ 5,507$ & $\$ 679,300$ \\
\hline 24 & $\$ 40,565$ & $\$ 2,370,129$ & $\$ 40,565$ & $\$ 2,370,129$ & 1,937 & 0.111678158 & $\$ 4,530$ & $\$ 683,831$ \\
\hline 25 & $\$ 36,705$ & $\$ 2,406,834$ & $\$ 36,705$ & $\$ 2,406,834$ & 1,753 & 0.101525598 & $\$ 3,727$ & $\$ 687,557$ \\
\hline 26 & $\$ 33,212$ & $\$ 2,440,046$ & $\$ 33,212$ & $\$ 2,440,046$ & 1,586 & 0.092295998 & $\$ 3,065$ & $\$ 690,622$ \\
\hline
\end{tabular}


Table 7.10_-Detailed Economic Analysis for a P50 Well with an F\&DC of \$2 Million. (Scenario II)

\begin{tabular}{|c|c|c|c|c|c|c|c|c|}
\hline & $\begin{array}{c}\text { Payout: } \\
\text { Payout Year: } \\
\text { Economic Limit Year: } \\
\$ 3,234,625\end{array}$ & $\begin{array}{c}4.61 \\
4 \\
26 \\
\$ 3,234,625\end{array}$ & $\$ 3,234,625$ & $\$ 3,234,625$ & $\begin{array}{l}1,350,000 \\
1,350,000\end{array}$ & & $\$ 900,997$ & $\$ 900,997$ \\
\hline $\begin{array}{l}\text { Time } \\
\text { (Years) }\end{array}$ & $\begin{array}{c}\text { Net } \\
\text { Cash Flow } \\
(\$) \\
\$ 0 \\
\end{array}$ & $\begin{array}{l}\text { Cum Net } \\
\text { Profit } \\
(\$) \\
\$ 0 \\
\end{array}$ & $\begin{array}{c}\text { Final } \\
\text { Net } \\
\text { Cash Flow } \\
(\$) \\
\$ 0 \\
\end{array}$ & $\begin{array}{c}\text { Final } \\
\text { Cum Net } \\
\text { Profit } \\
(\$) \\
\$ 0 \\
\end{array}$ & $\begin{array}{l}\text { Risked } \\
\text { Gross } \\
\text { Prod } \\
\text { (Mscf) } \\
\end{array}$ & $\begin{array}{l}\text { Discount } \\
\text { Factor } \\
\text { (\%/yr) }\end{array}$ & $\begin{array}{l}\text { Disc. } \\
\text { Profit } \\
(\$) \\
\$ 0 \\
\end{array}$ & $\begin{array}{l}\text { Cum } \\
\text { Disc. } \\
\text { Profit } \\
(\$) \\
\$ 0 \\
\end{array}$ \\
\hline 1 & $(\$ 2,000,000)$ & $(\$ 2,000,000)$ & $(\$ 2,000,000)$ & $(\$ 2,000,000)$ & 0 & 1 & $(\$ 2,000,000)$ & $(\$ 2,000,000)$ \\
\hline 2 & $\$ 857,481$ & $(\$ 1,142,519)$ & $\$ 857,481$ & $(\$ 1,142,519)$ & 221,143 & 0.909090909 & $\$ 779,528$ & $(\$ 1,220,472)$ \\
\hline 3 & $\$ 508,089$ & $(\$ 634,431)$ & $\$ 508,089$ & $(\$ 634,431)$ & 131,035 & 0.826446281 & $\$ 419,908$ & $(\$ 800,564)$ \\
\hline 4 & $\$ 414,567$ & $(\$ 219,864)$ & $\$ 414,567$ & $(\$ 219,864)$ & 106,916 & 0.751314801 & $\$ 311,470$ & $(\$ 489,094)$ \\
\hline 5 & $\$ 362,859$ & $\$ 142,996$ & $\$ 362,859$ & $\$ 142,996$ & 93,581 & 0.683013455 & $\$ 247,838$ & $(\$ 241,256)$ \\
\hline 6 & $\$ 327,081$ & $\$ 470,077$ & $\$ 327,081$ & $\$ 470,077$ & 84,354 & 0.620921323 & $\$ 203,092$ & $(\$ 38,164)$ \\
\hline 7 & $\$ 296,344$ & $\$ 766,421$ & $\$ 296,344$ & $\$ 766,421$ & 76,427 & 0.56447393 & $\$ 167,278$ & $\$ 129,114$ \\
\hline 8 & $\$ 268,820$ & $\$ 1,035,241$ & $\$ 268,820$ & $\$ 1,035,241$ & 69,328 & 0.513158118 & $\$ 137,947$ & $\$ 267,061$ \\
\hline 9 & $\$ 244,076$ & $\$ 1,279,317$ & $\$ 244,076$ & $\$ 1,279,317$ & 62,947 & 0.46650738 & $\$ 113,863$ & $\$ 380,925$ \\
\hline 10 & $\$ 221,690$ & $\$ 1,501,006$ & $\$ 221,690$ & $\$ 1,501,006$ & 57,173 & 0.424097618 & $\$ 94,018$ & $\$ 474,943$ \\
\hline 11 & $\$ 201,385$ & $\$ 1,702,392$ & $\$ 201,385$ & $\$ 1,702,392$ & 51,937 & 0.385543289 & $\$ 77,643$ & $\$ 552,585$ \\
\hline 12 & $\$ 182,967$ & $\$ 1,885,359$ & $\$ 182,967$ & $\$ 1,885,359$ & 47,187 & 0.350493899 & $\$ 64,129$ & $\$ 616,714$ \\
\hline 13 & $\$ 166,258$ & $\$ 2,051,617$ & $\$ 166,258$ & $\$ 2,051,617$ & 42,878 & 0.318630818 & $\$ 52,975$ & $\$ 669,689$ \\
\hline 14 & $\$ 151,098$ & $\$ 2,202,715$ & $\$ 151,098$ & $\$ 2,202,715$ & 38,968 & 0.28966438 & $\$ 43,768$ & $\$ 713,457$ \\
\hline 15 & $\$ 137,343$ & $\$ 2,340,058$ & $\$ 137,343$ & $\$ 2,340,058$ & 35,420 & 0.263331254 & $\$ 36,167$ & $\$ 749,624$ \\
\hline 16 & $\$ 124,860$ & $\$ 2,464,917$ & $\$ 124,860$ & $\$ 2,464,917$ & 32,201 & 0.239392049 & $\$ 29,890$ & $\$ 779,514$ \\
\hline 17 & $\$ 113,530$ & $\$ 2,578,448$ & $\$ 113,530$ & $\$ 2,578,448$ & 29,279 & 0.217629136 & $\$ 24,708$ & $\$ 804,221$ \\
\hline 18 & $\$ 103,247$ & $\$ 2,681,695$ & $\$ 103,247$ & $\$ 2,681,695$ & 26,627 & 0.197844669 & $\$ 20,427$ & $\$ 824,648$ \\
\hline 19 & $\$ 93,912$ & $\$ 2,775,607$ & $\$ 93,912$ & $\$ 2,775,607$ & 24,220 & 0.17985879 & $\$ 16,891$ & $\$ 841,539$ \\
\hline 20 & $\$ 85,437$ & $\$ 2,861,044$ & $\$ 85,437$ & $\$ 2,861,044$ & 22,034 & 0.163507991 & $\$ 13,970$ & $\$ 855,509$ \\
\hline 21 & $\$ 77,741$ & $\$ 2,938,785$ & $\$ 77,741$ & $\$ 2,938,785$ & 20,049 & 0.148643628 & $\$ 11,556$ & $\$ 867,065$ \\
\hline 22 & $\$ 70,753$ & $\$ 3,009,538$ & $\$ 70,753$ & $\$ 3,009,538$ & 18,247 & 0.135130571 & $\$ 9,561$ & $\$ 876,625$ \\
\hline 23 & $\$ 64,405$ & $\$ 3,073,943$ & $\$ 64,405$ & $\$ 3,073,943$ & 16,610 & 0.122845974 & $\$ 7,912$ & $\$ 884,537$ \\
\hline 24 & $\$ 58,639$ & $\$ 3,132,582$ & $\$ 58,639$ & $\$ 3,132,582$ & 15,123 & 0.111678158 & $\$ 6,549$ & $\$ 891,086$ \\
\hline 25 & $\$ 53,401$ & $\$ 3,185,984$ & $\$ 53,401$ & $\$ 3,185,984$ & 13,772 & 0.101525598 & $\$ 5,422$ & $\$ 896,508$ \\
\hline 26 & $\$ 48,641$ & $\$ 3,234,625$ & $\$ 48,641$ & $\$ 3,234,625$ & 12,545 & 0.092295998 & $\$ 4,489$ & $\$ 900,997$ \\
\hline
\end{tabular}


Table 7.11-Detailed Economic Analysis for a P90 Well with an F\&DC of \$2 Million.(Scenario II)

\begin{tabular}{|c|c|c|c|c|c|c|c|c|}
\hline & $\begin{array}{c}\text { Payout: } \\
\text { Payout Year: } \\
\text { Economic } \\
\text { Limit Year: } \\
\$ 4,091,200\end{array}$ & $\begin{array}{c}4.81 \\
4 \\
26 \\
\$ 4,091,200\end{array}$ & $\$ 4,091,200$ & $\$ 4,091,200$ & $\begin{array}{l}3,600,000 \\
3,600,000\end{array}$ & & $\$ 1,049,078$ & $\$ 1,049,078$ \\
\hline $\begin{array}{l}\text { Time } \\
\text { (Years) }\end{array}$ & $\begin{array}{c}\text { Net } \\
\text { Cash Flow } \\
(\$) \\
\$ 0 \\
\end{array}$ & $\begin{array}{c}\text { Cum Net } \\
\text { Profit } \\
(\$) \\
\$ 0\end{array}$ & $\begin{array}{c}\text { Final } \\
\text { Net } \\
\text { Cash Flow } \\
(\$) \\
\$ 0\end{array}$ & $\begin{array}{c}\text { Final } \\
\text { Cum Net } \\
\text { Profit } \\
(\$) \\
\$ 0 \\
\end{array}$ & $\begin{array}{c}\text { Risked } \\
\text { Gross } \\
\text { Prod } \\
\text { (Mscf) }\end{array}$ & $\begin{array}{l}\text { Discount } \\
\text { Factor } \\
\text { (\%/yr) }\end{array}$ & $\begin{array}{l}\text { Disc. } \\
\text { Profit } \\
(\$) \\
\$ 0 \\
\end{array}$ & $\begin{array}{l}\text { Cum } \\
\text { Disc. } \\
\text { Profit } \\
(\$) \\
\$ 0 \\
\end{array}$ \\
\hline 1 & $(\$ 2,000,000)$ & $(\$ 2,000,000)$ & $(\$ 2,000,000)$ & $(\$ 2,000,000)$ & 0 & 1 & $(\$ 2,000,000)$ & $(\$ 2,000,000)$ \\
\hline 2 & $\$ 744,786$ & $(\$ 1,255,214)$ & $\$ 744,786$ & $(\$ 1,255,214)$ & 440,181 & 0.909090909 & $\$ 677,078$ & $(\$ 1,322,922)$ \\
\hline 3 & $\$ 522,108$ & $(\$ 733,106)$ & $\$ 522,108$ & $(\$ 733,106)$ & 308,575 & 0.826446281 & $\$ 431,494$ & $(\$ 891,427)$ \\
\hline 4 & $\$ 429,973$ & $(\$ 303,132)$ & $\$ 429,973$ & $(\$ 303,132)$ & 254,121 & 0.751314801 & $\$ 323,045$ & $(\$ 568,382)$ \\
\hline 5 & $\$ 375,476$ & $\$ 72,343$ & $\$ 375,476$ & $\$ 72,343$ & 221,912 & 0.683013455 & $\$ 256,455$ & $(\$ 311,927)$ \\
\hline 6 & $\$ 338,254$ & $\$ 410,597$ & $\$ 338,254$ & $\$ 410,597$ & 199,914 & 0.620921323 & $\$ 210,029$ & $(\$ 101,898)$ \\
\hline 7 & $\$ 310,697$ & $\$ 721,294$ & $\$ 310,697$ & $\$ 721,294$ & 183,627 & 0.56447393 & $\$ 175,381$ & $\$ 73,482$ \\
\hline 8 & $\$ 289,206$ & $\$ 1,010,500$ & $\$ 289,206$ & $\$ 1,010,500$ & 170,925 & 0.513158118 & $\$ 148,408$ & $\$ 221,891$ \\
\hline 9 & $\$ 271,664$ & $\$ 1,282,164$ & $\$ 271,664$ & $\$ 1,282,164$ & 160,558 & 0.46650738 & $\$ 126,733$ & $\$ 348,624$ \\
\hline 10 & $\$ 255,840$ & $\$ 1,538,004$ & $\$ 255,840$ & $\$ 1,538,004$ & 151,206 & 0.424097618 & $\$ 108,501$ & $\$ 457,125$ \\
\hline 11 & $\$ 240,941$ & $\$ 1,778,946$ & $\$ 240,941$ & $\$ 1,778,946$ & 142,400 & 0.385543289 & $\$ 92,893$ & $\$ 550,019$ \\
\hline 12 & $\$ 226,910$ & $\$ 2,005,856$ & $\$ 226,910$ & $\$ 2,005,856$ & 134,107 & 0.350493899 & $\$ 79,531$ & $\$ 629,549$ \\
\hline 13 & $\$ 213,696$ & $\$ 2,219,551$ & $\$ 213,696$ & $\$ 2,219,551$ & 126,298 & 0.318630818 & $\$ 68,090$ & $\$ 697,639$ \\
\hline 14 & $\$ 201,251$ & $\$ 2,420,802$ & $\$ 201,251$ & $\$ 2,420,802$ & 118,943 & 0.28966438 & $\$ 58,295$ & $\$ 755,934$ \\
\hline 15 & $\$ 189,531$ & $\$ 2,610,333$ & $\$ 189,531$ & $\$ 2,610,333$ & 112,016 & 0.263331254 & $\$ 49,909$ & $\$ 805,844$ \\
\hline 16 & $\$ 178,494$ & $\$ 2,788,827$ & $\$ 178,494$ & $\$ 2,788,827$ & 105,493 & 0.239392049 & $\$ 42,730$ & $\$ 848,574$ \\
\hline 17 & $\$ 168,099$ & $\$ 2,956,926$ & $\$ 168,099$ & $\$ 2,956,926$ & 99,349 & 0.217629136 & $\$ 36,583$ & $\$ 885,157$ \\
\hline 18 & $\$ 158,310$ & $\$ 3,115,236$ & $\$ 158,310$ & $\$ 3,115,236$ & 93,564 & 0.197844669 & $\$ 31,321$ & $\$ 916,478$ \\
\hline 19 & $\$ 149,090$ & $\$ 3,264,326$ & $\$ 149,090$ & $\$ 3,264,326$ & 88,115 & 0.17985879 & $\$ 26,815$ & $\$ 943,293$ \\
\hline 20 & $\$ 140,408$ & $\$ 3,404,734$ & $\$ 140,408$ & $\$ 3,404,734$ & 82,983 & 0.163507991 & $\$ 22,958$ & $\$ 966,251$ \\
\hline 21 & $\$ 132,231$ & $\$ 3,536,965$ & $\$ 132,231$ & $\$ 3,536,965$ & 78,151 & 0.148643628 & $\$ 19,655$ & $\$ 985,906$ \\
\hline 22 & $\$ 124,531$ & $\$ 3,661,496$ & $\$ 124,531$ & $\$ 3,661,496$ & 73,600 & 0.135130571 & $\$ 16,828$ & $\$ 1,002,734$ \\
\hline 23 & $\$ 117,279$ & $\$ 3,778,775$ & $\$ 117,279$ & $\$ 3,778,775$ & 69,314 & 0.122845974 & $\$ 14,407$ & $\$ 1,017,141$ \\
\hline 24 & $\$ 110,449$ & $\$ 3,889,224$ & $\$ 110,449$ & $\$ 3,889,224$ & 65,277 & 0.111678158 & $\$ 12,335$ & $\$ 1,029,476$ \\
\hline 25 & $\$ 104,017$ & $\$ 3,993,241$ & $\$ 104,017$ & $\$ 3,993,241$ & 61,476 & 0.101525598 & $\$ 10,560$ & $\$ 1,040,036$ \\
\hline 26 & $\$ 97,959$ & $\$ 4,091,200$ & $\$ 97,959$ & $\$ 4,091,200$ & 57,896 & 0.092295998 & $\$ 9,041$ & $\$ 1,049,078$ \\
\hline
\end{tabular}


Table 7.12-Detailed Economic Analysis for a $\mathrm{P}^{*}$ Well with an F\&DC of \$2 Million.(Scenario II)

\begin{tabular}{|c|c|c|c|c|c|c|c|c|}
\hline & $\begin{array}{c}\text { Payout: } \\
\text { Payout Year: } \\
\text { Economic Limit Year: } \\
\$ 3,932,575\end{array}$ & $\begin{array}{c}4.28 \\
4 \\
26 \\
\$ 3,932,575\end{array}$ & $\$ 3,932,575$ & $\$ 3,932,575$ & $\begin{array}{l}1,530,000 \\
1,530,000\end{array}$ & & $\$ 1,172,339$ & $\$ 1,172,339$ \\
\hline $\begin{array}{l}\text { Time } \\
\text { (Years) }\end{array}$ & $\begin{array}{c}\text { Net } \\
\text { Cash Flow } \\
(\$) \\
\$ 0\end{array}$ & $\begin{array}{l}\text { Cum Net } \\
\text { Profit } \\
(\$) \\
\$ 0\end{array}$ & $\begin{array}{c}\text { Final } \\
\text { Net } \\
\text { Cash Flow } \\
\text { (\$) } \\
\$ 0\end{array}$ & $\begin{array}{c}\text { Final } \\
\text { Cum Net } \\
\text { Profit } \\
(\$) \\
\$ 0 \\
\end{array}$ & $\begin{array}{l}\text { Risked } \\
\text { Gross } \\
\text { Prod } \\
\text { (Mscf) }\end{array}$ & $\begin{array}{l}\text { Discount } \\
\text { Factor } \\
\text { (\%/yr) }\end{array}$ & $\begin{array}{l}\text { Disc. } \\
\text { Profit } \\
(\$) \\
\$ 0\end{array}$ & $\begin{array}{l}\text { Cum } \\
\text { Disc. } \\
\text { Profit } \\
(\$) \\
\$ 0 \\
\end{array}$ \\
\hline 1 & $(\$ 2,000,000)$ & $(\$ 2,000,000)$ & $(\$ 2,000,000)$ & $(\$ 2,000,000)$ & 0 & 1 & $(\$ 2,000,000)$ & $(\$ 2,000,000)$ \\
\hline 2 & $\$ 886,315$ & $(\$ 1,113,685)$ & $\$ 886,315$ & $(\$ 1,113,685)$ & 228,579 & 0.909090909 & $\$ 805,741$ & $(\$ 1,194,259)$ \\
\hline 3 & $\$ 551,085$ & $(\$ 562,600)$ & $\$ 551,085$ & $(\$ 562,600)$ & 142,124 & 0.826446281 & $\$ 455,443$ & $(\$ 738,817)$ \\
\hline 4 & $\$ 450,492$ & $(\$ 112,108)$ & $\$ 450,492$ & $(\$ 112,108)$ & 116,181 & 0.751314801 & $\$ 338,461$ & $(\$ 400,355)$ \\
\hline 5 & $\$ 393,670$ & $\$ 281,562$ & $\$ 393,670$ & $\$ 281,562$ & 101,527 & 0.683013455 & $\$ 268,882$ & $(\$ 131,474)$ \\
\hline 6 & $\$ 354,613$ & $\$ 636,175$ & $\$ 354,613$ & $\$ 636,175$ & 91,454 & 0.620921323 & $\$ 220,187$ & $\$ 88,713$ \\
\hline 7 & $\$ 322,805$ & $\$ 958,980$ & $\$ 322,805$ & $\$ 958,980$ & 83,251 & 0.56447393 & $\$ 182,215$ & $\$ 270,928$ \\
\hline 8 & $\$ 295,507$ & $\$ 1,254,487$ & $\$ 295,507$ & $\$ 1,254,487$ & 76,211 & 0.513158118 & $\$ 151,642$ & $\$ 422,570$ \\
\hline 9 & $\$ 271,615$ & $\$ 1,526,102$ & $\$ 271,615$ & $\$ 1,526,102$ & 70,049 & 0.46650738 & $\$ 126,710$ & $\$ 549,280$ \\
\hline 10 & $\$ 250,016$ & $\$ 1,776,117$ & $\$ 250,016$ & $\$ 1,776,117$ & 64,479 & 0.424097618 & $\$ 106,031$ & $\$ 655,311$ \\
\hline 11 & $\$ 230,227$ & $\$ 2,006,344$ & $\$ 230,227$ & $\$ 2,006,344$ & 59,375 & 0.385543289 & $\$ 88,762$ & $\$ 744,073$ \\
\hline 12 & $\$ 212,087$ & $\$ 2,218,431$ & $\$ 212,087$ & $\$ 2,218,431$ & 54,697 & 0.350493899 & $\$ 74,335$ & $\$ 818,409$ \\
\hline 13 & $\$ 195,455$ & $\$ 2,413,886$ & $\$ 195,455$ & $\$ 2,413,886$ & 50,407 & 0.318630818 & $\$ 62,278$ & $\$ 880,687$ \\
\hline 14 & $\$ 180,198$ & $\$ 2,594,084$ & $\$ 180,198$ & $\$ 2,594,084$ & 46,473 & 0.28966438 & $\$ 52,197$ & $\$ 932,884$ \\
\hline 15 & $\$ 166,199$ & $\$ 2,760,282$ & $\$ 166,199$ & $\$ 2,760,282$ & 42,862 & 0.263331254 & $\$ 43,765$ & $\$ 976,649$ \\
\hline 16 & $\$ 153,348$ & $\$ 2,913,631$ & $\$ 153,348$ & $\$ 2,913,631$ & 39,548 & 0.239392049 & $\$ 36,710$ & $\$ 1,013,359$ \\
\hline 17 & $\$ 141,548$ & $\$ 3,055,178$ & $\$ 141,548$ & $\$ 3,055,178$ & 36,505 & 0.217629136 & $\$ 30,805$ & $\$ 1,044,164$ \\
\hline 18 & $\$ 130,708$ & $\$ 3,185,886$ & $\$ 130,708$ & $\$ 3,185,886$ & 33,709 & 0.197844669 & $\$ 25,860$ & $\$ 1,070,024$ \\
\hline 19 & $\$ 120,746$ & $\$ 3,306,632$ & $\$ 120,746$ & $\$ 3,306,632$ & 31,140 & 0.17985879 & $\$ 21,717$ & $\$ 1,091,741$ \\
\hline 20 & $\$ 111,588$ & $\$ 3,418,220$ & $\$ 111,588$ & $\$ 3,418,220$ & 28,778 & 0.163507991 & $\$ 18,246$ & $\$ 1,109,987$ \\
\hline 21 & $\$ 103,166$ & $\$ 3,521,386$ & $\$ 103,166$ & $\$ 3,521,386$ & 26,606 & 0.148643628 & $\$ 15,335$ & $\$ 1,125,322$ \\
\hline 22 & $\$ 95,417$ & $\$ 3,616,804$ & $\$ 95,417$ & $\$ 3,616,804$ & 24,608 & 0.135130571 & $\$ 12,894$ & $\$ 1,138,216$ \\
\hline 23 & $\$ 88,285$ & $\$ 3,705,089$ & $\$ 88,285$ & $\$ 3,705,089$ & 22,769 & 0.122845974 & $\$ 10,846$ & $\$ 1,149,061$ \\
\hline 24 & $\$ 81,719$ & $\$ 3,786,808$ & $\$ 81,719$ & $\$ 3,786,808$ & 21,075 & 0.111678158 & $\$ 9,126$ & $\$ 1,158,187$ \\
\hline 25 & $\$ 75,670$ & $\$ 3,862,478$ & $\$ 75,670$ & $\$ 3,862,478$ & 19,515 & 0.101525598 & $\$ 7,682$ & $\$ 1,165,870$ \\
\hline 26 & $\$ 70,097$ & $\$ 3,932,575$ & $\$ 70,097$ & $\$ 3,932,575$ & 18,078 & 0.092295998 & $\$ 6,470$ & $\$ 1,172,339$ \\
\hline
\end{tabular}


Table 7.13 summarizes the gas prices required to make P10, P50, P90, and $\mathrm{P} *$ wells meet our investment hurdle for ROR and Payout.

Table 7.13—ROR and Payout Periods for P10, P50, P90, and P* with an F\&DC of \$2 Million (Scenario II)

\begin{tabular}{|c|c|c|c|c|}
\hline & P10 Well & P50 Well & P90 Well & P $^{*}$ Well \\
\hline EUR (Bcf) & .203 & 1.35 & 3.6 & 1.53 \\
\hline Gas Price $(\$$ Mcf) & 30.70 & 6.50 & 3.40 & 6.10 \\
\hline Payout Period (Years) & 4.4 & 4.6 & 4.6 & 4.6 \\
\hline ROR $(\%)$ & 20 & 20 & 22 & 21 \\
\hline
\end{tabular}

\subsection{Determining TRR from a $\mathrm{P} *$ Well}

A $\mathrm{P}^{*}$ well has an EUR value that is probabilistically weighted on the EUR values of P10, P50, and P90. As mentioned in section 7.1, the EUR value for a $\mathrm{P}^{*}$ Well is calculated as follows:

$$
\begin{aligned}
& \mathrm{P} * \text { Weighted EUR }=\mathrm{P} 10 \mathrm{EUR} * 16 \%+\mathrm{P} 50 \mathrm{EUR} * 68 \%+\mathrm{P} 90 \mathrm{EUR} * 16 \% \\
& \mathrm{P} * \text { Weighted EUR }=(0.250 * 0.16)+(1.5 * 0.68)+(4.0 * 0.16)=1.7 \mathrm{Bcf}
\end{aligned}
$$

Knowing the area of an unconventional gas play, the well-spacing requirement, and the EUR value of $\mathrm{P}^{*}$ Well, we can determine TRR for the gas play. For example, the Barnett Shale's estimated basin area is 5,000 square miles, which is equivalent to 3,200,000 acres. Using a well spacing of 160 acres, and the weighted EUR value of $\mathrm{P} *$ 
Well, TRR for the Barnett Shale is calculated, using our proposed methodology, to be approximately $44.5 \mathrm{Tcf}$.

\subsection{Sensitivity Analysis}

To better understand the impact of changes in F\&DC, LOE, and EUR on ROR for the Barnett Shale, we used $\mathrm{P}^{*}$ Well to perform a sensitivity analysis for each of the four factors. From Table 7.13, a P* Well has an EUR value of $1.53 \mathrm{Bcf}$ and will require a gas price of $\$ 6.10 / \mathrm{Mcf}$ to yield a $21 \%$ ROR and payout its F\&DC in 4.6 years at a LOE of \$1.0/Mcf. Starting with these initial values for EUR, F\&DC, gas price, and LOE, we varied each parameter independently and recorded the resulting change in ROR (Table 7.14 and Fig. 7.5).If the gas price is reduced by $15 \%$, from $\$ 6.10 / \mathrm{Mcf}$ to $\$ 5.19 / \mathrm{Mcf}$, ROR will decline by $28.72 \%$ from $20.27 \%$ to $14.45 \%$ (Table 7.14 ). Similarly, if F\&DC decreases by $15 \%$, ROR will increase by $29.12 \%$ from $20.27 \%$ to $26.18 \%$. ROR is less sensitive to changes in LOE and most sensitive to changes in F\&DC and gas price (Fig. 7.5). 
Table 7.14-Sensitivity Analysis for Barnett Shale Based on a P* Well

\begin{tabular}{|c|c|c|c|c|c|c|c|c|c|c|c|}
\hline \multicolumn{3}{|c|}{ Gas Price } & \multicolumn{3}{|c|}{$L O E$} & \multicolumn{3}{|c|}{$\begin{array}{c}\begin{array}{c}\text { Finding \& } \\
\text { Development } \\
\text { Costs }\end{array} \\
\end{array}$} & \multicolumn{3}{|c|}{ EUR } \\
\hline $\begin{array}{l}\text { Change } \\
\text { In } \\
\text { Parameter }\end{array}$ & ROR & $\begin{array}{c}\text { Change } \\
\text { In } \\
\text { ROR }\end{array}$ & $\begin{array}{c}\text { Change } \\
\text { In } \\
\text { Parameter }\end{array}$ & ROR & $\begin{array}{c}\text { Change } \\
\text { In } \\
\text { ROR }\end{array}$ & $\begin{array}{c}\text { Change } \\
\text { In } \\
\text { Parameter }\end{array}$ & ROR & $\begin{array}{c}\text { Change } \\
\text { In } \\
\text { ROR }\end{array}$ & $\begin{array}{c}\text { Change } \\
\text { In } \\
\text { Parameter }\end{array}$ & ROR & $\begin{array}{c}\text { Change } \\
\text { In } \\
\text { ROR }\end{array}$ \\
\hline$-90 \%$ & $-1000.00 \%$ & $-5032.99 \%$ & $-90 \%$ & $26.18 \%$ & $29.12 \%$ & $-90 \%$ & $375.92 \%$ & $1754.43 \%$ & $-90 \%$ & $-11.83 \%$ & $-158.33 \%$ \\
\hline$-75 \%$ & $-10.68 \%$ & $-152.69 \%$ & $-75 \%$ & $25.18 \%$ & $24.21 \%$ & $-75 \%$ & $133.04 \%$ & $556.30 \%$ & $-75 \%$ & $-4.36 \%$ & $-121.52 \%$ \\
\hline$-50 \%$ & $1.26 \%$ & $-93.80 \%$ & $-50 \%$ & $23.53 \%$ & $16.07 \%$ & $-50 \%$ & $55.59 \%$ & $174.24 \%$ & $-50 \%$ & $4.66 \%$ & $-77.00 \%$ \\
\hline$-30 \%$ & $8.79 \%$ & $-56.65 \%$ & $-30 \%$ & $22.22 \%$ & $9.61 \%$ & $-30 \%$ & $34.89 \%$ & $72.12 \%$ & $-30 \%$ & $11.01 \%$ & $-45.71 \%$ \\
\hline$-15 \%$ & $14.45 \%$ & $-28.72 \%$ & $-15 \%$ & $21.24 \%$ & $4.79 \%$ & $-15 \%$ & $26.18 \%$ & $29.12 \%$ & $-15 \%$ & $15.69 \%$ & $-22.60 \%$ \\
\hline $0 \%$ & $20.27 \%$ & $0.00 \%$ & $0 \%$ & $20.27 \%$ & $0.00 \%$ & $0 \%$ & $20.27 \%$ & $0.00 \%$ & $0 \%$ & $20.27 \%$ & $0.00 \%$ \\
\hline $15 \%$ & $26.27 \%$ & $29.61 \%$ & $15 \%$ & $19.30 \%$ & $-4.77 \%$ & $15 \%$ & $16.02 \%$ & $-20.97 \%$ & $15 \%$ & $24.43 \%$ & $20.49 \%$ \\
\hline $30 \%$ & $32.45 \%$ & $60.07 \%$ & $30 \%$ & $18.34 \%$ & $-9.51 \%$ & $30 \%$ & $12.82 \%$ & $-36.78 \%$ & $30 \%$ & $28.56 \%$ & $40.91 \%$ \\
\hline $50 \%$ & $40.91 \%$ & $101.81 \%$ & $50 \%$ & $17.07 \%$ & $-15.80 \%$ & $50 \%$ & $9.59 \%$ & $-52.72 \%$ & $50 \%$ & $34.09 \%$ & $68.16 \%$ \\
\hline $75 \%$ & $51.79 \%$ & $155.46 \%$ & $75 \%$ & $15.49 \%$ & $-23.60 \%$ & $75 \%$ & $6.61 \%$ & $-67.39 \%$ & $75 \%$ & $41.02 \%$ & $102.37 \%$ \\
\hline $90 \%$ & $58.44 \%$ & $188.28 \%$ & $90 \%$ & $14.54 \%$ & $-28.25 \%$ & $90 \%$ & $5.20 \%$ & $-74.35 \%$ & $90 \%$ & $45.20 \%$ & $122.98 \%$ \\
\hline
\end{tabular}


EFFECT OF CHANGE IN ASSUMPTIONS UPON THE RATE OF RETURN (ROR)

Barnett Shale Reserves

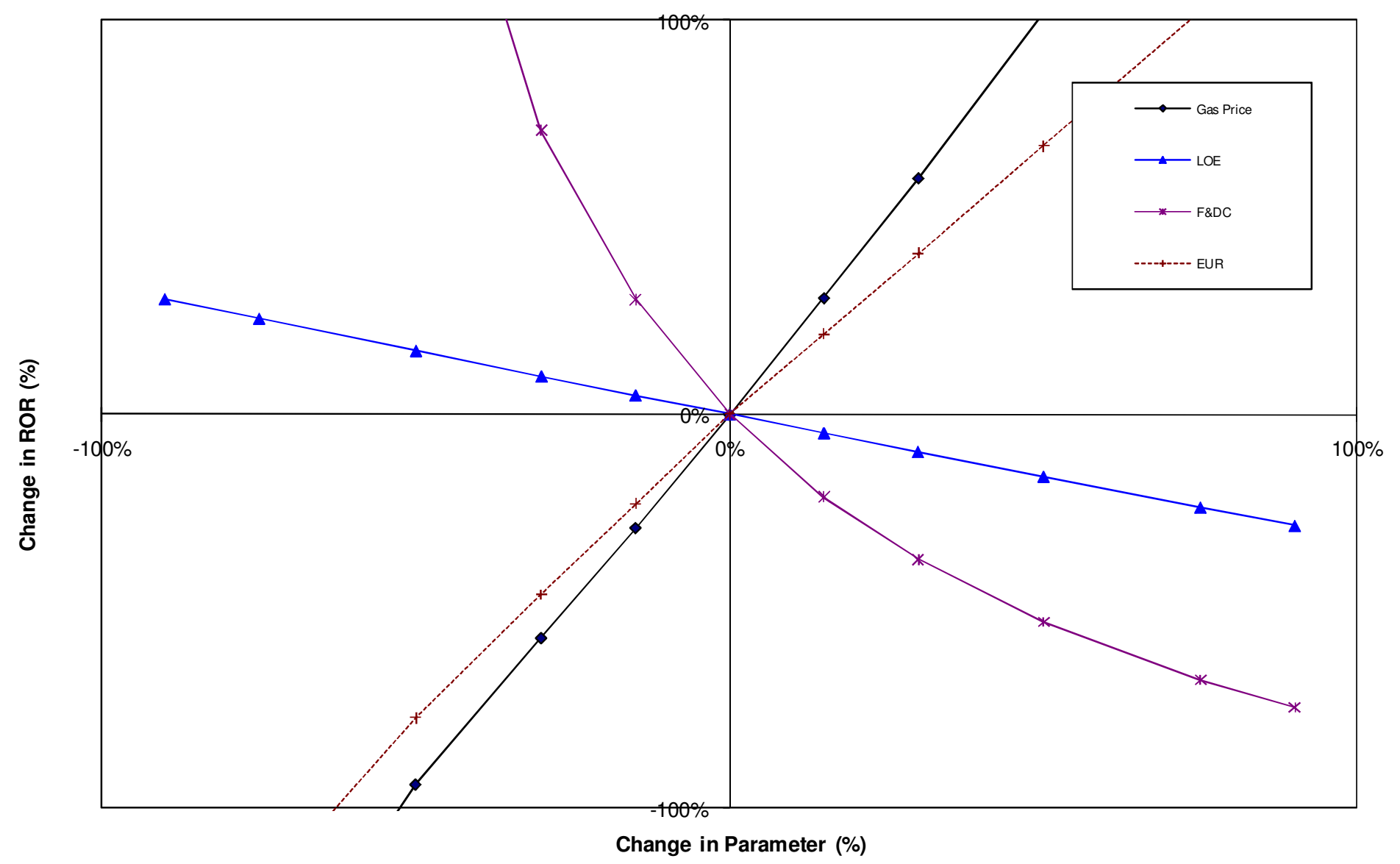

Fig. 7.5-Sensitivity Analysis Chart for Barnett Shale Based on a P* Well. 


\subsection{Economic Analysis at Every Percentile}

Since the EUR values at the $10^{\text {th }}$ percentile, $50^{\text {th }}$ percentile, and $90^{\text {th }}$ percentile are known, we extrapolated and interpolated the EUR values for every percentile with P10 = $0.250 \mathrm{Bcf}, \mathrm{P} 50=1.5 \mathrm{Bcf}$, and $\mathrm{P} 90=4.0 \mathrm{Bcf}$. This was done based on our research finding that EUR values for an unconventional gas resource are log-normally distributed. For example, the EUR calculated for P20 is $0.460 \mathrm{Bcf}$ and $2.86 \mathrm{Bcf}$ for P80.

We then ran detailed economic analysis for a hypothetical well with the EUR at each percentile and at a range of F\&D costs. The gas prices to meet the investment hurdle for each percentile bases on Scenario II are summarized in Table 7.15.

Table 7.15-Gas Price Required to Meet the Investment-Hurdle Criteria at Every

Percentile for Different F\&D Costs

\begin{tabular}{|c|c|c|c|c|c|c|c|c|c|}
\hline$\%$-tile & F\&DC & $\$ 500,000$ & $\$ 1,000,000$ & $\$ 1,500,000$ & $\$ 2,000,000$ & $\$ 2,500,000$ & $\$ 3,000,000$ & $\$ 3,500,000$ & $\$ 4,000,000$ \\
\hline $\mathbf{P}$ & EUR & & & & & & & & \\
\hline $1 \%$ & 0.06 & $\$ 31.90$ & $\$ 62.80$ & $\$ 93.60$ & $\$ 124.50$ & $\$ 155.30$ & $\$ 186.20$ & $\$ 217.00$ & $\$ 247.90$ \\
\hline $2 \%$ & 0.08 & $\$ 24.20$ & $\$ 47.30$ & $\$ 70.50$ & $\$ 93.60$ & $\$ 116.80$ & $\$ 139.90$ & $\$ 163.00$ & $\$ 186.20$ \\
\hline $3 \%$ & 0.11 & $\$ 17.90$ & $\$ 34.70$ & $\$ 51.50$ & $\$ 68.40$ & $\$ 85.20$ & $\$ 102.00$ & $\$ 118.90$ & $\$ 135.70$ \\
\hline $4 \%$ & 0.13 & $\$ 15.30$ & $\$ 29.50$ & $\$ 43.80$ & $\$ 58.00$ & $\$ 72.30$ & $\$ 86.50$ & $\$ 100.70$ & $\$ 115.00$ \\
\hline $5 \%$ & 0.15 & $\$ 13.40$ & $\$ 25.70$ & $\$ 38.10$ & $\$ 50.40$ & $\$ 62.80$ & $\$ 75.10$ & $\$ 87.40$ & $\$ 99.80$ \\
\hline $6 \%$ & 0.17 & $\$ 11.90$ & $\$ 22.80$ & $\$ 33.70$ & $\$ 44.60$ & $\$ 55.50$ & $\$ 66.40$ & $\$ 77.30$ & $\$ 88.20$ \\
\hline $7 \%$ & 0.19 & $\$ 10.80$ & $\$ 20.50$ & $\$ 30.30$ & $\$ 40.00$ & $\$ 49.80$ & $\$ 59.50$ & $\$ 69.30$ & $\$ 79.00$ \\
\hline $8 \%$ & 0.21 & $\$ 9.90$ & $\$ 18.70$ & $\$ 27.50$ & $\$ 36.30$ & $\$ 45.10$ & $\$ 53.90$ & $\$ 62.80$ & $\$ 71.60$ \\
\hline $9 \%$ & 0.23 & $\$ 9.10$ & $\$ 17.10$ & $\$ 25.20$ & $\$ 33.20$ & $\$ 41.30$ & $\$ 49.30$ & $\$ 57.40$ & $\$ 65.40$ \\
\hline $10 \%$ & 0.25 & $\$ 8.50$ & $\$ 16.00$ & $\$ 23.40$ & $\$ 30.90$ & $\$ 38.30$ & $\$ 45.80$ & $\$ 53.20$ & $\$ 60.70$ \\
\hline $11 \%$ & 0.27 & $\$ 8.00$ & $\$ 15.00$ & $\$ 21.90$ & $\$ 28.90$ & $\$ 35.80$ & $\$ 42.80$ & $\$ 49.70$ & $\$ 56.70$ \\
\hline $12 \%$ & 0.29 & $\$ 7.60$ & $\$ 14.10$ & $\$ 20.60$ & $\$ 27.10$ & $\$ 33.60$ & $\$ 40.10$ & $\$ 46.60$ & $\$ 53.10$ \\
\hline $13 \%$ & 0.31 & $\$ 7.20$ & $\$ 13.30$ & $\$ 19.40$ & $\$ 25.50$ & $\$ 31.60$ & $\$ 37.80$ & $\$ 43.90$ & $\$ 50.00$ \\
\hline $14 \%$ & 0.33 & $\$ 6.80$ & $\$ 12.60$ & $\$ 18.40$ & $\$ 24.10$ & $\$ 29.90$ & $\$ 35.70$ & $\$ 41.50$ & $\$ 47.20$ \\
\hline $15 \%$ & 0.35 & $\$ 6.50$ & $\$ 12.00$ & $\$ 17.40$ & $\$ 22.90$ & $\$ 28.40$ & $\$ 33.80$ & $\$ 39.30$ & $\$ 44.80$ \\
\hline $16 \%$ & 0.37 & $\$ 6.20$ & $\$ 11.40$ & $\$ 16.60$ & $\$ 21.80$ & $\$ 27.00$ & $\$ 32.20$ & $\$ 37.40$ & $\$ 42.60$ \\
\hline
\end{tabular}


Table 7.15-Continued

\begin{tabular}{|c|c|c|c|c|c|c|c|c|c|}
\hline$\%$-tile & F\&DC & $\$ 500,000$ & $\$ 1,000,000$ & $\$ 1,500,000$ & $\$ 2,000,000$ & $\$ 2,500,000$ & $\$ 3,000,000$ & $\$ 3,500,000$ & $\$ 4,000,000$ \\
\hline $\mathbf{P}$ & EUR & & & & & & & & \\
\hline $17 \%$ & 0.4 & $\$ 5.90$ & $\$ 10.70$ & $\$ 15.50$ & $\$ 20.30$ & $\$ 25.20$ & $\$ 30.00$ & $\$ 34.80$ & $\$ 39.60$ \\
\hline $18 \%$ & 0.42 & $\$ 5.70$ & $\$ 10.30$ & $\$ 14.90$ & $\$ 19.50$ & $\$ 24.10$ & $\$ 28.70$ & $\$ 33.30$ & $\$ 37.90$ \\
\hline $19 \%$ & 0.44 & $\$ 5.50$ & $\$ 9.90$ & $\$ 14.30$ & $\$ 18.70$ & $\$ 23.10$ & $\$ 27.50$ & $\$ 31.90$ & $\$ 36.30$ \\
\hline $20 \%$ & 0.46 & $\$ 5.30$ & $\$ 9.50$ & $\$ 13.70$ & $\$ 17.90$ & $\$ 22.20$ & $\$ 26.40$ & $\$ 30.60$ & $\$ 34.80$ \\
\hline $21 \%$ & 0.49 & $\$ 5.00$ & $\$ 9.00$ & $\$ 13.00$ & $\$ 17.00$ & $\$ 20.90$ & $\$ 24.90$ & $\$ 28.90$ & $\$ 32.90$ \\
\hline $22 \%$ & 0.51 & $\$ 4.90$ & $\$ 8.70$ & $\$ 12.50$ & $\$ 16.40$ & $\$ 20.20$ & $\$ 24.00$ & $\$ 27.90$ & $\$ 31.70$ \\
\hline $23 \%$ & 0.53 & $\$ 4.70$ & $\$ 8.40$ & $\$ 12.10$ & $\$ 15.80$ & $\$ 19.50$ & $\$ 23.20$ & $\$ 26.90$ & $\$ 30.60$ \\
\hline $24 \%$ & 0.56 & $\$ 4.60$ & $\$ 8.10$ & $\$ 11.60$ & $\$ 15.10$ & $\$ 18.60$ & $\$ 22.10$ & $\$ 25.60$ & $\$ 29.10$ \\
\hline $25 \%$ & 0.58 & $\$ 4.40$ & $\$ 7.80$ & $\$ 11.20$ & $\$ 14.60$ & $\$ 18.00$ & $\$ 21.40$ & $\$ 24.70$ & $\$ 28.10$ \\
\hline $26 \%$ & 0.61 & $\$ 4.30$ & $\$ 7.50$ & $\$ 10.70$ & $\$ 14.00$ & $\$ 17.20$ & $\$ 20.40$ & $\$ 23.60$ & $\$ 26.90$ \\
\hline $27 \%$ & 0.64 & $\$ 4.10$ & $\$ 7.20$ & $\$ 10.30$ & $\$ 13.40$ & $\$ 16.40$ & $\$ 19.50$ & $\$ 22.60$ & $\$ 25.70$ \\
\hline $28 \%$ & 0.66 & $\$ 4.00$ & $\$ 7.00$ & $\$ 10.00$ & $\$ 13.00$ & $\$ 16.00$ & $\$ 19.00$ & $\$ 22.00$ & $\$ 25.00$ \\
\hline $29 \%$ & 0.69 & $\$ 3.90$ & $\$ 6.80$ & $\$ 9.60$ & $\$ 12.50$ & $\$ 15.40$ & $\$ 18.20$ & $\$ 21.10$ & $\$ 24.00$ \\
\hline $30 \%$ & 0.72 & $\$ 3.80$ & $\$ 6.50$ & $\$ 9.30$ & $\$ 12.00$ & $\$ 14.80$ & $\$ 17.50$ & $\$ 20.30$ & $\$ 23.00$ \\
\hline $31 \%$ & 0.75 & $\$ 3.70$ & $\$ 6.30$ & $\$ 9.00$ & $\$ 11.60$ & $\$ 14.30$ & $\$ 16.90$ & $\$ 19.50$ & $\$ 22.20$ \\
\hline $32 \%$ & 0.78 & $\$ 3.60$ & $\$ 6.10$ & $\$ 8.70$ & $\$ 11.20$ & $\$ 13.80$ & $\$ 16.30$ & $\$ 18.90$ & $\$ 21.40$ \\
\hline $33 \%$ & 0.81 & $\$ 3.50$ & $\$ 6.00$ & $\$ 8.40$ & $\$ 10.90$ & $\$ 13.30$ & $\$ 15.80$ & $\$ 18.20$ & $\$ 20.70$ \\
\hline $34 \%$ & 0.84 & $\$ 3.40$ & $\$ 5.80$ & $\$ 8.20$ & $\$ 10.50$ & $\$ 12.90$ & $\$ 15.30$ & $\$ 17.60$ & $\$ 20.00$ \\
\hline $35 \%$ & 0.88 & $\$ 3.30$ & $\$ 5.60$ & $\$ 7.80$ & $\$ 10.10$ & $\$ 12.40$ & $\$ 14.60$ & $\$ 16.90$ & $\$ 19.20$ \\
\hline $36 \%$ & 0.91 & $\$ 3.20$ & $\$ 5.40$ & $\$ 7.60$ & $\$ 9.80$ & $\$ 12.00$ & $\$ 14.20$ & $\$ 16.40$ & $\$ 18.60$ \\
\hline $37 \%$ & 0.94 & $\$ 3.20$ & $\$ 5.30$ & $\$ 7.40$ & $\$ 9.50$ & $\$ 11.70$ & $\$ 13.80$ & $\$ 15.90$ & $\$ 18.00$ \\
\hline $38 \%$ & 0.98 & $\$ 3.10$ & $\$ 5.10$ & $\$ 7.20$ & $\$ 9.20$ & $\$ 11.20$ & $\$ 13.30$ & $\$ 15.30$ & $\$ 17.30$ \\
\hline $39 \%$ & 1.02 & $\$ 3.00$ & $\$ 5.00$ & $\$ 6.90$ & $\$ 8.90$ & $\$ 10.80$ & $\$ 12.80$ & $\$ 14.80$ & $\$ 16.70$ \\
\hline $40 \%$ & 1.05 & $\$ 3.00$ & $\$ 4.90$ & $\$ 6.80$ & $\$ 8.70$ & $\$ 10.60$ & $\$ 12.50$ & $\$ 14.40$ & $\$ 16.30$ \\
\hline $41 \%$ & 1.09 & $\$ 2.90$ & $\$ 4.70$ & $\$ 6.60$ & $\$ 8.40$ & $\$ 10.20$ & $\$ 12.10$ & $\$ 13.90$ & $\$ 15.70$ \\
\hline $42 \%$ & 1.13 & $\$ 2.80$ & $\$ 4.60$ & $\$ 6.40$ & $\$ 8.10$ & $\$ 9.90$ & $\$ 11.70$ & $\$ 13.50$ & $\$ 15.20$ \\
\hline $43 \%$ & 1.17 & $\$ 2.80$ & $\$ 4.50$ & $\$ 6.20$ & $\$ 7.90$ & $\$ 9.60$ & $\$ 11.30$ & $\$ 13.00$ & $\$ 14.80$ \\
\hline $44 \%$ & 1.22 & $\$ 2.70$ & $\$ 4.30$ & $\$ 6.00$ & $\$ 7.60$ & $\$ 9.30$ & $\$ 10.90$ & $\$ 12.60$ & $\$ 14.20$ \\
\hline $45 \%$ & 1.26 & $\$ 2.60$ & $\$ 4.20$ & $\$ 5.80$ & $\$ 7.40$ & $\$ 9.00$ & $\$ 10.60$ & $\$ 12.20$ & $\$ 13.80$ \\
\hline $46 \%$ & 1.3 & $\$ 2.60$ & $\$ 4.10$ & $\$ 5.70$ & $\$ 7.20$ & $\$ 8.80$ & $\$ 10.30$ & $\$ 11.90$ & $\$ 13.40$ \\
\hline $47 \%$ & 1.35 & $\$ 2.50$ & $\$ 4.00$ & $\$ 5.50$ & $\$ 7.00$ & $\$ 8.50$ & $\$ 10.00$ & $\$ 11.50$ & $\$ 13.00$ \\
\hline $48 \%$ & 1.4 & $\$ 2.50$ & $\$ 3.90$ & $\$ 5.40$ & $\$ 6.80$ & $\$ 8.20$ & $\$ 9.70$ & $\$ 11.10$ & $\$ 12.50$ \\
\hline
\end{tabular}


Table 7.15-Continued

\begin{tabular}{|c|c|c|c|c|c|c|c|c|c|}
\hline$\%$-tile & F\&DC & $\$ 500,000$ & $\$ 1,000,000$ & $\$ 1,500,000$ & $\$ 2,000,000$ & $\$ 2,500,000$ & $\$ 3,000,000$ & $\$ 3,500,000$ & $\$ 4,000,000$ \\
\hline $\mathbf{P}$ & EUR & & & & & & & & \\
\hline $49 \%$ & 1.45 & $\$ 2.40$ & $\$ 3.80$ & $\$ 5.20$ & $\$ 6.60$ & $\$ 8.00$ & $\$ 9.40$ & $\$ 10.80$ & $\$ 12.20$ \\
\hline $50 \%$ & 1.5 & $\$ 2.40$ & $\$ 3.80$ & $\$ 5.10$ & $\$ 6.50$ & $\$ 7.90$ & $\$ 9.20$ & $\$ 10.60$ & $\$ 11.90$ \\
\hline $51 \%$ & 1.53 & $\$ 2.40$ & $\$ 3.70$ & $\$ 5.10$ & $\$ 6.40$ & $\$ 7.80$ & $\$ 9.10$ & $\$ 10.40$ & $\$ 11.80$ \\
\hline $52 \%$ & 1.56 & $\$ 2.40$ & $\$ 3.70$ & $\$ 5.00$ & $\$ 6.30$ & $\$ 7.70$ & $\$ 9.00$ & $\$ 10.30$ & $\$ 11.60$ \\
\hline $53 \%$ & 1.59 & $\$ 2.40$ & $\$ 3.70$ & $\$ 5.00$ & $\$ 6.30$ & $\$ 7.60$ & $\$ 8.90$ & $\$ 10.20$ & $\$ 11.50$ \\
\hline $54 \%$ & 1.62 & $\$ 2.30$ & $\$ 3.60$ & $\$ 4.90$ & $\$ 6.20$ & $\$ 7.50$ & $\$ 8.80$ & $\$ 10.00$ & $\$ 11.30$ \\
\hline $55 \%$ & 1.65 & $\$ 2.30$ & $\$ 3.60$ & $\$ 4.80$ & $\$ 6.10$ & $\$ 7.40$ & $\$ 8.60$ & $\$ 9.90$ & $\$ 11.20$ \\
\hline $56 \%$ & 1.68 & $\$ 2.30$ & $\$ 3.50$ & $\$ 4.80$ & $\$ 6.00$ & $\$ 7.30$ & $\$ 8.50$ & $\$ 9.80$ & $\$ 11.00$ \\
\hline $57 \%$ & 1.72 & $\$ 2.30$ & $\$ 3.50$ & $\$ 4.70$ & $\$ 6.00$ & $\$ 7.20$ & $\$ 8.40$ & $\$ 9.60$ & $\$ 10.90$ \\
\hline $58 \%$ & 1.75 & $\$ 2.30$ & $\$ 3.50$ & $\$ 4.70$ & $\$ 5.90$ & $\$ 7.10$ & $\$ 8.30$ & $\$ 9.50$ & $\$ 10.70$ \\
\hline $59 \%$ & 1.78 & $\$ 2.20$ & $\$ 3.40$ & $\$ 4.60$ & $\$ 5.80$ & $\$ 7.00$ & $\$ 8.20$ & $\$ 9.40$ & $\$ 10.60$ \\
\hline $60 \%$ & 1.82 & $\$ 2.20$ & $\$ 3.40$ & $\$ 4.60$ & $\$ 5.70$ & $\$ 6.90$ & $\$ 8.10$ & $\$ 9.30$ & $\$ 10.40$ \\
\hline $61 \%$ & 1.86 & $\$ 2.20$ & $\$ 3.40$ & $\$ 4.50$ & $\$ 5.70$ & $\$ 6.80$ & $\$ 8.00$ & $\$ 9.10$ & $\$ 10.30$ \\
\hline $62 \%$ & 1.89 & $\$ 2.20$ & $\$ 3.30$ & $\$ 4.50$ & $\$ 5.60$ & $\$ 6.70$ & $\$ 7.90$ & $\$ 9.00$ & $\$ 10.10$ \\
\hline $63 \%$ & 1.93 & $\$ 2.20$ & $\$ 3.30$ & $\$ 4.40$ & $\$ 5.50$ & $\$ 6.60$ & $\$ 7.80$ & $\$ 8.90$ & $\$ 10.00$ \\
\hline $64 \%$ & 1.97 & $\$ 2.20$ & $\$ 3.30$ & $\$ 4.40$ & $\$ 5.50$ & $\$ 6.60$ & $\$ 7.70$ & $\$ 8.80$ & $\$ 9.90$ \\
\hline $65 \%$ & 2.01 & $\$ 2.10$ & $\$ 3.20$ & $\$ 4.30$ & $\$ 5.40$ & $\$ 6.50$ & $\$ 7.50$ & $\$ 8.60$ & $\$ 9.70$ \\
\hline $66 \%$ & 2.06 & $\$ 2.10$ & $\$ 3.20$ & $\$ 4.20$ & $\$ 5.30$ & $\$ 6.40$ & $\$ 7.40$ & $\$ 8.50$ & $\$ 9.50$ \\
\hline $67 \%$ & 2.1 & $\$ 2.10$ & $\$ 3.10$ & $\$ 4.20$ & $\$ 5.20$ & $\$ 6.30$ & $\$ 7.30$ & $\$ 8.40$ & $\$ 9.40$ \\
\hline $68 \%$ & 2.14 & $\$ 2.10$ & $\$ 3.10$ & $\$ 4.10$ & $\$ 5.20$ & $\$ 6.20$ & $\$ 7.20$ & $\$ 8.30$ & $\$ 9.30$ \\
\hline $69 \%$ & 2.19 & $\$ 2.10$ & $\$ 3.10$ & $\$ 4.10$ & $\$ 5.10$ & $\$ 6.10$ & $\$ 7.10$ & $\$ 8.10$ & $\$ 9.10$ \\
\hline $70 \%$ & 2.24 & $\$ 2.00$ & $\$ 3.00$ & $\$ 4.00$ & $\$ 5.00$ & $\$ 6.00$ & $\$ 7.00$ & $\$ 8.00$ & $\$ 9.00$ \\
\hline $71 \%$ & 2.29 & $\$ 2.00$ & $\$ 3.00$ & $\$ 4.00$ & $\$ 4.90$ & $\$ 5.90$ & $\$ 6.90$ & $\$ 7.90$ & $\$ 8.80$ \\
\hline $72 \%$ & 2.34 & $\$ 2.00$ & $\$ 3.00$ & $\$ 3.90$ & $\$ 4.90$ & $\$ 5.80$ & $\$ 6.80$ & $\$ 7.70$ & $\$ 8.70$ \\
\hline $73 \%$ & 2.4 & $\$ 2.00$ & $\$ 2.90$ & $\$ 3.90$ & $\$ 4.80$ & $\$ 5.70$ & $\$ 6.70$ & $\$ 7.60$ & $\$ 8.50$ \\
\hline $74 \%$ & 2.45 & $\$ 2.00$ & $\$ 2.90$ & $\$ 3.80$ & $\$ 4.70$ & $\$ 5.60$ & $\$ 6.60$ & $\$ 7.50$ & $\$ 8.40$ \\
\hline $75 \%$ & 2.51 & $\$ 2.00$ & $\$ 2.90$ & $\$ 3.80$ & $\$ 4.70$ & $\$ 5.60$ & $\$ 6.50$ & $\$ 7.40$ & $\$ 8.30$ \\
\hline $76 \%$ & 2.57 & $\$ 1.90$ & $\$ 2.80$ & $\$ 3.70$ & $\$ 4.60$ & $\$ 5.50$ & $\$ 6.40$ & $\$ 7.20$ & $\$ 8.10$ \\
\hline $77 \%$ & 2.64 & $\$ 1.90$ & $\$ 2.80$ & $\$ 3.60$ & $\$ 4.50$ & $\$ 5.40$ & $\$ 6.20$ & $\$ 7.10$ & $\$ 8.00$ \\
\hline $78 \%$ & 2.71 & $\$ 1.90$ & $\$ 2.70$ & $\$ 3.60$ & $\$ 4.40$ & $\$ 5.30$ & $\$ 6.10$ & $\$ 7.00$ & $\$ 7.80$ \\
\hline $79 \%$ & 2.78 & $\$ 1.90$ & $\$ 2.70$ & $\$ 3.50$ & $\$ 4.40$ & $\$ 5.20$ & $\$ 6.00$ & $\$ 6.80$ & $\$ 7.70$ \\
\hline $80 \%$ & 2.86 & $\$ 1.90$ & $\$ 2.70$ & $\$ 3.50$ & $\$ 4.30$ & $\$ 5.10$ & $\$ 5.90$ & $\$ 6.70$ & $\$ 7.50$ \\
\hline
\end{tabular}


Table 7.15-Continued

\begin{tabular}{|c|c|c|c|c|c|c|c|c|c|}
\hline$\%$-tile & F\&DC & $\$ 500,000$ & $\$ 1,000,000$ & $\$ 1,500,000$ & $\$ 2,000,000$ & $\$ 2,500,000$ & $\$ 3,000,000$ & $\$ 3,500,000$ & $\$ 4,000,000$ \\
\hline $\mathbf{P}$ & EUR & & & & & & & & \\
\hline $81 \%$ & 2.94 & $\$ 1.80$ & $\$ 2.60$ & $\$ 3.40$ & $\$ 4.20$ & $\$ 5.00$ & $\$ 5.80$ & $\$ 6.60$ & $\$ 7.40$ \\
\hline $82 \%$ & 3.02 & $\$ 1.80$ & $\$ 2.60$ & $\$ 3.40$ & $\$ 4.10$ & $\$ 4.90$ & $\$ 5.70$ & $\$ 6.40$ & $\$ 7.20$ \\
\hline $83 \%$ & 3.11 & $\$ 1.80$ & $\$ 2.60$ & $\$ 3.30$ & $\$ 4.10$ & $\$ 4.80$ & $\$ 5.60$ & $\$ 6.30$ & $\$ 7.10$ \\
\hline $84 \%$ & 3.21 & $\$ 1.80$ & $\$ 2.50$ & $\$ 3.20$ & $\$ 4.00$ & $\$ 4.70$ & $\$ 5.40$ & $\$ 6.20$ & $\$ 6.90$ \\
\hline $85 \%$ & 3.32 & $\$ 1.80$ & $\$ 2.50$ & $\$ 3.20$ & $\$ 3.90$ & $\$ 4.60$ & $\$ 5.30$ & $\$ 6.00$ & $\$ 6.70$ \\
\hline $86 \%$ & 3.43 & $\$ 1.70$ & $\$ 2.40$ & $\$ 3.10$ & $\$ 3.80$ & $\$ 4.50$ & $\$ 5.20$ & $\$ 5.90$ & $\$ 6.60$ \\
\hline $87 \%$ & 3.55 & $\$ 1.70$ & $\$ 2.40$ & $\$ 3.10$ & $\$ 3.70$ & $\$ 4.40$ & $\$ 5.10$ & $\$ 5.70$ & $\$ 6.40$ \\
\hline $88 \%$ & 3.69 & $\$ 1.70$ & $\$ 2.30$ & $\$ 3.00$ & $\$ 3.60$ & $\$ 4.30$ & $\$ 4.90$ & $\$ 5.50$ & $\$ 6.20$ \\
\hline $89 \%$ & 3.83 & $\$ 1.70$ & $\$ 2.30$ & $\$ 2.90$ & $\$ 3.50$ & $\$ 4.10$ & $\$ 4.80$ & $\$ 5.40$ & $\$ 6.00$ \\
\hline $90 \%$ & 4 & $\$ 1.60$ & $\$ 2.20$ & $\$ 2.80$ & $\$ 3.40$ & $\$ 4.00$ & $\$ 4.60$ & $\$ 5.20$ & $\$ 5.80$ \\
\hline $91 \%$ & 4.19 & $\$ 1.60$ & $\$ 2.20$ & $\$ 2.70$ & $\$ 3.30$ & $\$ 3.90$ & $\$ 4.40$ & $\$ 5.00$ & $\$ 5.60$ \\
\hline $92 \%$ & 4.4 & $\$ 1.60$ & $\$ 2.10$ & $\$ 2.70$ & $\$ 3.20$ & $\$ 3.70$ & $\$ 4.30$ & $\$ 4.80$ & $\$ 5.40$ \\
\hline $93 \%$ & 4.64 & $\$ 1.60$ & $\$ 2.10$ & $\$ 2.60$ & $\$ 3.10$ & $\$ 3.60$ & $\$ 4.10$ & $\$ 4.60$ & $\$ 5.10$ \\
\hline $94 \%$ & 4.93 & $\$ 1.50$ & $\$ 2.00$ & $\$ 2.50$ & $\$ 3.00$ & $\$ 3.50$ & $\$ 3.90$ & $\$ 4.40$ & $\$ 4.90$ \\
\hline $95 \%$ & 5.28 & $\$ 1.50$ & $\$ 1.90$ & $\$ 2.40$ & $\$ 2.80$ & $\$ 3.30$ & $\$ 3.70$ & $\$ 4.20$ & $\$ 4.60$ \\
\hline $96 \%$ & 5.73 & $\$ 1.50$ & $\$ 1.90$ & $\$ 2.30$ & $\$ 2.70$ & $\$ 3.10$ & $\$ 3.50$ & $\$ 3.90$ & $\$ 4.40$ \\
\hline $97 \%$ & 6.33 & $\$ 1.40$ & $\$ 1.80$ & $\$ 2.20$ & $\$ 2.50$ & $\$ 2.90$ & $\$ 3.30$ & $\$ 3.70$ & $\$ 4.00$ \\
\hline $98 \%$ & 7.22 & $\$ 1.40$ & $\$ 1.70$ & $\$ 2.00$ & $\$ 2.40$ & $\$ 2.70$ & $\$ 3.00$ & $\$ 3.30$ & $\$ 3.70$ \\
\hline $99 \%$ & 8.9 & $\$ 1.30$ & $\$ 1.60$ & $\$ 1.80$ & $\$ 2.10$ & $\$ 2.40$ & $\$ 2.60$ & $\$ 2.90$ & $\$ 3.20$ \\
\hline
\end{tabular}

The same data are plotted and shown in Fig. 7.6. As the EUR value increases with each percentile for a specific F\&DC, the required gas prices to meet the specified investment hurdle decreases. For example, a well with a $\$ 4$ million F\&DC, an EUR value of $4.0 \mathrm{Bcf}$ (at the $90^{\text {th }}$ percentile), $\$ 1.0 \mathrm{LOE} / \mathrm{Mcf}$, and $25 \%$ royalty burden will require a $\$ 5.8 / \mathrm{Mcf}$ gas price during its 25 -year life to have at least $20 \%$ ROR and pay out its F\&DC in five years or less. 


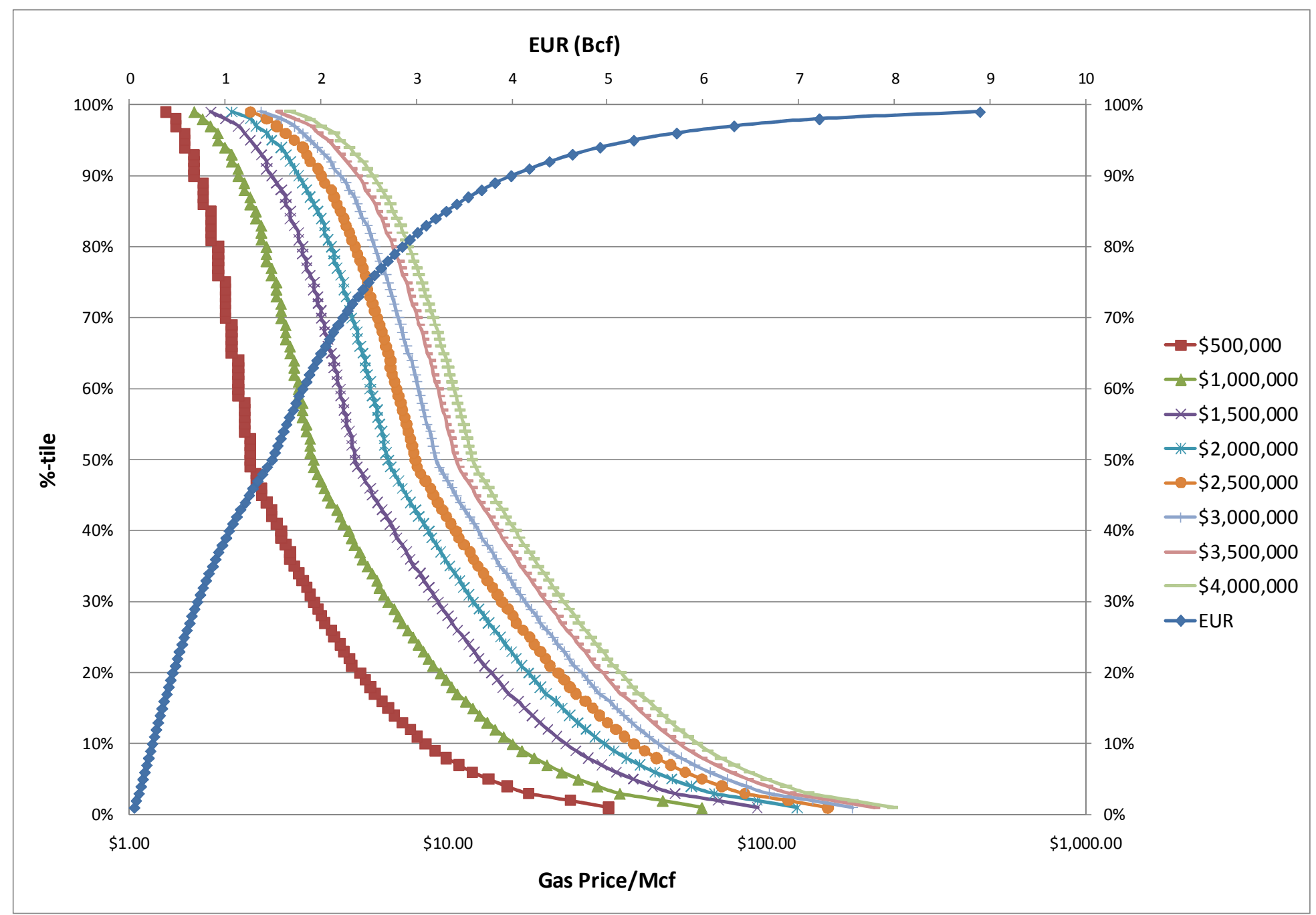

Fig. 7.6-Gas Prices To Meet the Investment-Hurdle for Each Percentile for Different F\&DC. 


\section{DISCUSSION OF RESULTS}

In addition to calculating the required gas price for each percentile for the Barnett Shale gas EUR cumulative distribution at different F\&DCs, and using the data in Table 7.15, we can determine the fraction of EUR that is economically recoverable. For instance, at P90 (EUR value of $4.0 \mathrm{Bcf}$ ), and an F\&DC of \$2 million, the required gas price is $\$ 3.40 / \mathrm{Mcf}$ to meet our investment hurdle. Hence, at $\$ 3.40 / \mathrm{Mcf}$, we conclude that $10 \%$ of the Barnett Shale gas is economically recoverable. Consider another example. At P40 (EUR value of $1.05 \mathrm{Bcf}$ ), and an F\&DC of $\$ 3$ million, the required gas price is $\$ 12.50 / \mathrm{Mcf}$ to meet our minimum investment hurdle. Hence, at $\$ 12.50 / \mathrm{Mcf}$, we conclude that $60 \%$ of the Barnett Shale gas is economically recoverable.

Using the results from Table 7.15, the ratio ERR/TRR (which represents the percentage of the fraction of TRR that is economically recoverable) was plotted with F\&DC ranging from $\$ 500,000$ to $\$ 4$ million versus the required gas prices to make the resource economical in a Radar Chart (Fig. 8.1). This chart shows, for example, that at \$4 million F\&DC, \$1.0 LOE/Mcf, and a 25\%royalty burden, $75 \%$ of the Barnett Shale gas will be economically recoverable at a gas price that is approximately $\$ 28.0 / \mathrm{Mcf}$. Another example is that at $\$ 1$ million F\&DC, $\$ 1.0 \mathrm{LOE} / \mathrm{Mcf}$, and a $25 \%$ royalty burden, $5 \%$ of the Barnett Shale gas will be economically recoverable at a gas price that is approximately $\$ 1.9 / \mathrm{Mcf}$. 


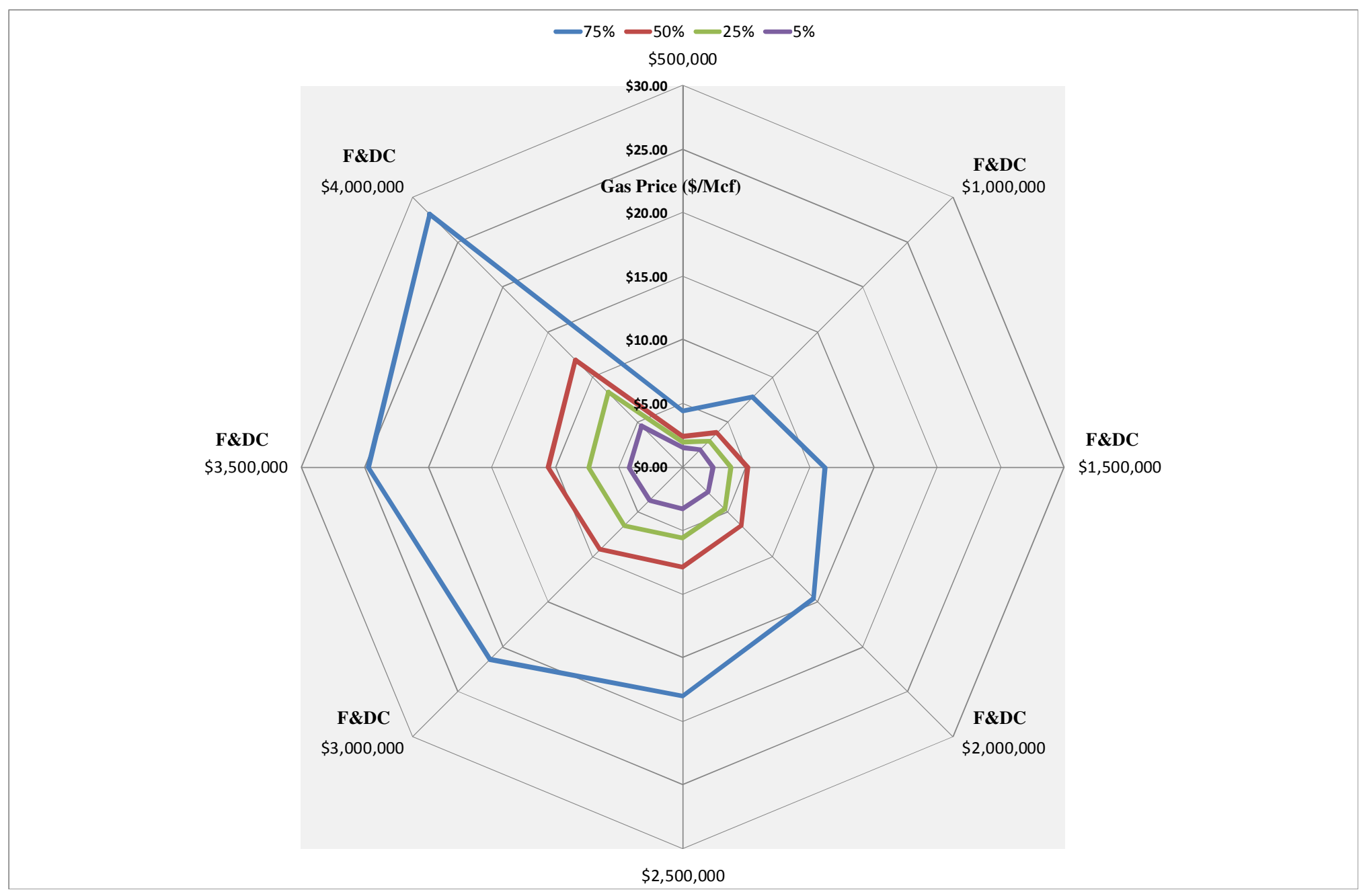

Fig. 8.1—Required Gas Prices for Different F\&DCs at Selected ERR/TRR. 
From the data calculated in Table 7.15, Fig. 8.2 illustrates the relation between changes in gas prices per Mcf and the percentage of ERR/TRR for a range of F\&D costs. As the F\&DC increases, for example, from $\$ 1$ million to $\$ 4$ million, the gas price required to economically recover $90 \%$ of the Barnett shale increases from $\$ 16.00 / \mathrm{Mcf}$ to \$60.70/Mcf. Fig. 8.2 displays the same information on a semi-log graph. Fig. 8.2 and Fig 8.3 can be used to estimate ERR for the Barnett Shale at a specific gas price and a specific F\&DC. Table 8.1 illustrates the percentage of TRR that is economically recoverable for the Barnett Shale gas at different F\&D Costs and gas prices of $\$ 3, \$ 4, \$ 5$, and $\$ 10 /$ Mcf.

Table 8.1-ERR/TRR for the Barnett Shale at Different F\&D Costs and Gas Prices of $\$ 3, \$ 4, \$ 5$, and $\$ 10 / \mathrm{Mcf}$

\begin{tabular}{|c|c|c|c|c|c|c|c|c|c|}
\hline $\begin{array}{c}\text { Gas } \\
\text { Price } \\
\text { /Mcf }\end{array}$ & F\&DC & $\mathbf{\$ 5 0 0 , 0 0 0}$ & $\mathbf{\$ 1 , 0 0 0 , 0 0 0}$ & $\mathbf{\$ 1 , 5 0 0 , 0 0 0}$ & $\mathbf{\$ 2 , 0 0 0 , 0 0 0}$ & $\mathbf{\$ 2 , 5 0 0 , 0 0 0}$ & $\mathbf{\$ 3 , 0 0 0 , 0 0 0}$ & $\mathbf{\$ 3 , 5 0 0 , 0 0 0}$ & $\mathbf{\$ 4 , 0 0 0 , 0 0 0}$ \\
\hline $\mathbf{\$ 3}$ & & $60 \%$ & $30 \%$ & $12 \%$ & $6 \%$ & $3 \%$ & $2 \%$ & $1 \%$ & $0 \%$ \\
\hline $\mathbf{\$ 4}$ & & $72 \%$ & $53 \%$ & $30 \%$ & $16 \%$ & $10 \%$ & $6 \%$ & $4 \%$ & $3 \%$ \\
\hline $\mathbf{5 5}$ & & $79 \%$ & $61 \%$ & $48 \%$ & $30 \%$ & $19 \%$ & $12 \%$ & $9 \%$ & $6 \%$ \\
\hline $\mathbf{1 0}$ & & $92 \%$ & $81 \%$ & $72 \%$ & $65 \%$ & $58 \%$ & $53 \%$ & $46 \%$ & $37 \%$ \\
\hline
\end{tabular}




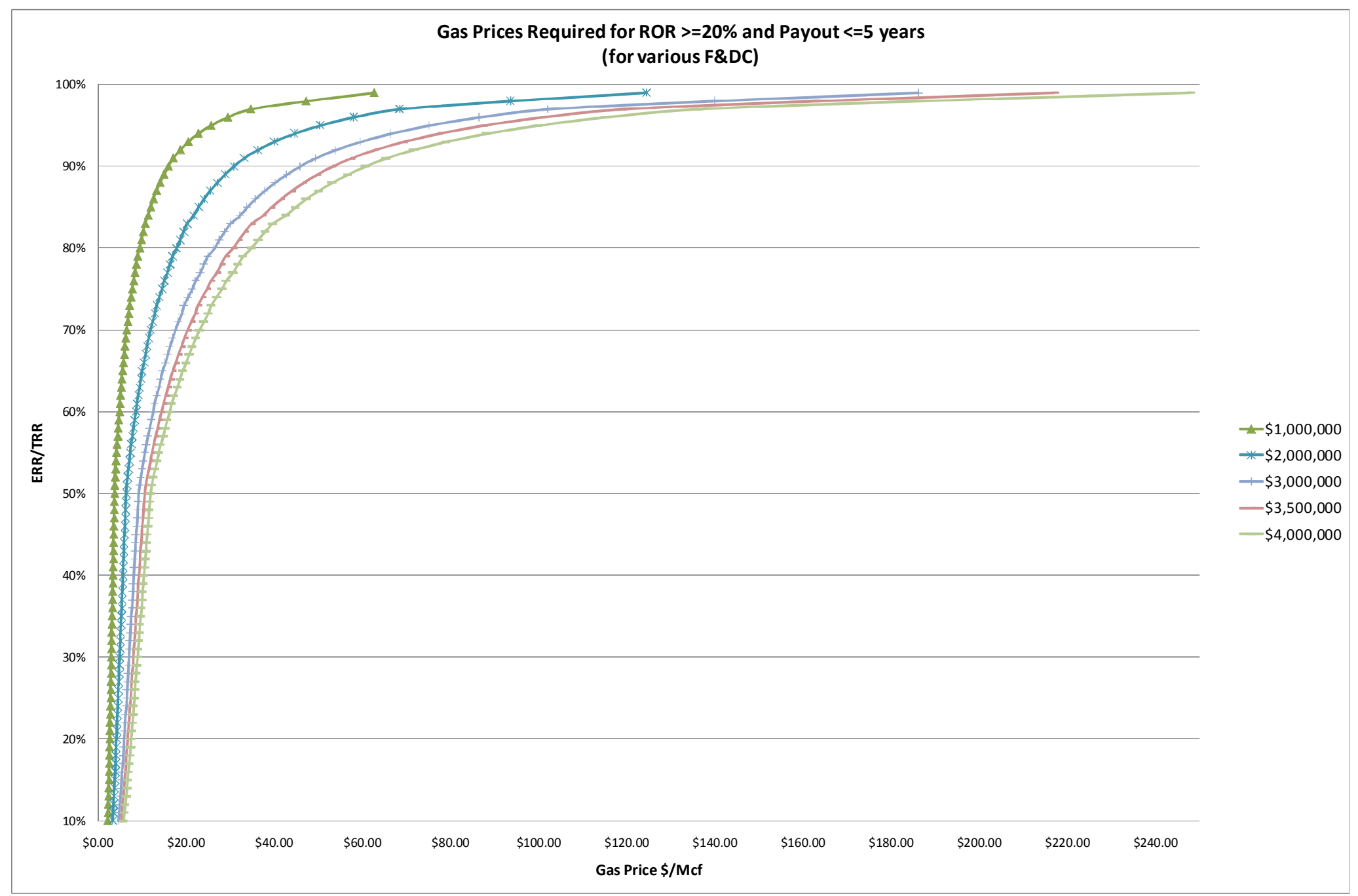

Fig. 8.2-Percentage of ERR/TRR at Different Gas Prices and Different F\&DCs. 


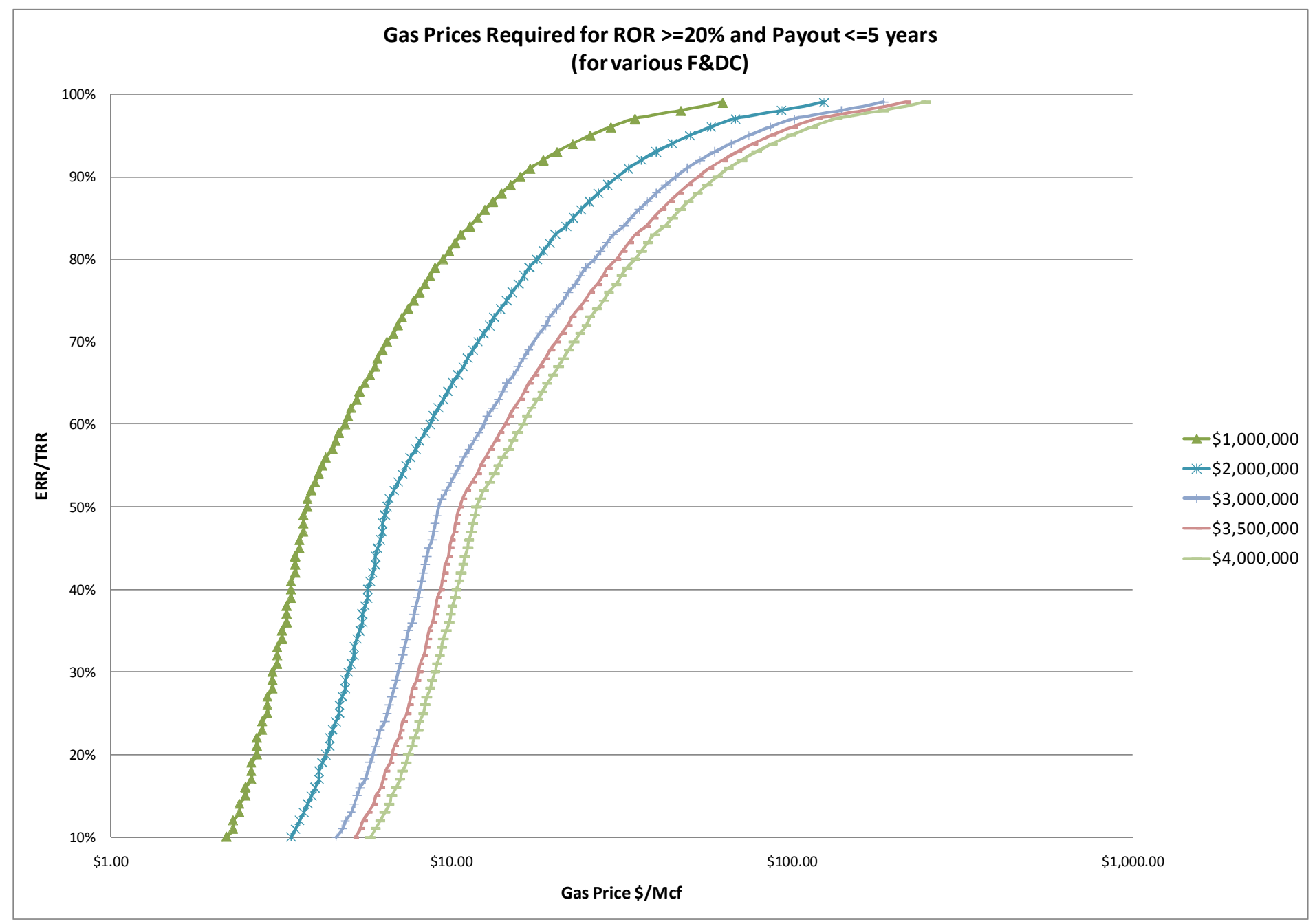

Fig. 8.3-Percentage of ERR/TRR at Different Gas Prices and Different F\&DCs on a Semi-Log Scale. 


\section{CONCLUSIONS AND RECOMMENDATIONS}

Our research led us to the following conclusions:

- EUR values for unconventional gas resources are log-normally distributed. This finding allows engineers to use our proposed methodology to estimate TRR and ERR using the P10, P50, and P90 EUR values for an unconventional gas play.

- While many analyst and engineers use PV10 value greater than zero as an indication that a well is economic to drill, our research indicates that investors in the oil and gas industry usually require a minimum of $20 \%$ ROR and a maximum of 5-year payout to recover initial investment before they consider investing in a development project. Hence, when evaluating the economic feasibility of a TRR for an unconventional gas play, we recommend using our proposed investment-hurdle criteria.

- ROR for new development in the Barnett Shale is less sensitive to changes in LOE and most sensitive to changes in F\&DC and gas price.

- The percentage of TRR that is economically recoverable (ERR/TRR) is dependent on the F\&DC, LOE, and gas price.

- At F\&DC of $\$ 3$ million:

- $90 \%$ of Barnett Shale gas is economically recoverable at a gas price of $\$ 46 / \mathrm{Mcf}$; 
- $75 \%$ of Barnett Shale gas is economically recoverable at a gas price of $\$ 24.7 / \mathrm{Mcf}$;

- $50 \%$ of Barnett Shale gas is economically recoverable at a gas price of \$9.2/Mcf; and

- $10 \%$ of Barnett Shale gas is economically recoverable at a gas price of \$5.2/Mcf.

- Advancements in drilling and completion technologies that can result in reduction of F\&DC will significantly impact the ERR/TRR ratio. At a gas price of \$7.89/Mcf:

- If F\&DC is $\$ 4$ million, approximately $22 \%$ of Barnett Shale is economically recoverable.

- If F\&DC is reduced to $\$ 2$ million, approximately $57 \%$ of Barnett Shale will be economically recoverable.

- If F\&DC can be further reduced to $\$ 1$ million, approximately $75 \%$ of Barnett Shale will be economically recoverable.

- Based on our analysis of the Barnett Shale gas data, the gas price required to meet our specified investment-hurdle criteria can be approximately estimated using the following correlation:

Gas Price $=(\mathrm{F} \& D C$ per Mcf $) *(2.77)+($ LOE per Mcf $)$

- Our proposed methodology of using the P10 $\left(10^{\text {th }}\right.$ percentile $)$, P50 $\left(50^{\text {th }}\right.$ percentile), and $\mathrm{P} 90$ ( $90^{\text {th }}$ percentile) from CDF, to calculate the technically recoverable resource (TRR) for a gas play, and determine the economically 
recoverable resource (ERR) as a function of finding and development cost (F\&DC), lease operating expenses (LOE), and gas price can be used to reduce uncertainties for investments in development of unconventional gas plays.

- Our proposed methodology, selected investment hurdle criteria, and developed software can be used to quantify TRR and ERR for other unconventional gas plays based on F\&DC, LOE, and gas price. 


\section{REFERENCES}

CME Group, 2010. Henry Hub Natural Gas Futures, http://www.cmegroup.com/trading/energy/natural-gas/natural-gas.html.

Cook, T. 2005. Calculation of Estimated Ultimate Recovery (EUR) for Wells in Continuous-Type Oil and Gas Accumulations. U.S. Geological Survey, Denver, Colorado.

EIA, 2007. Annual Energy Review. US DOE, Washington, DC.

EIA, 2008. Is US Natural Gas Production Increasing?, http://tonto.eia.doe.gov/energy_in_brief/natural_gas_production.cfm.

EIA, 2010a, Factors Affecting Natural Gas Prices http://tonto.eia.doe.gov/energyexplained/index.cfm?page=natural_gas_factors_affecti ng_prices.

EIA, 2010b. Annual Energy Outlook 2010, US DOE, Washington, DC.

Frantz, J.H., Jr., J.R. Williamson, W.K. Sawyer, SPE, D. Johnston, G. Waters, L.P. Moore, et al. 2005. Evaluating Barnett Shale Production Performance Using an Integrated Approach, Paper SPE 96917 presented at the SPE Annual Technical Conference and Exhibition, Dallas, Texas, 9-12 October.

Hayden, J. and Pursell, D, 2005. The Barnett Shale, Visitors Guide to the Hottest Gas Play in the US. Pickering Energy Partners, Houston, TX.

Herold, J.S, 2009. Global Upstream Performance Review 2006 \& 2007, IHS Herold, Houston, TX. 
Holditch, S.A. 2006. Tight Gas Sands, SPE Paper 103356, Distinguished Author Series.

Kawata, Y. and Fujita, K. 2001. Some Predictions of Possible Unconventional Hydrocarbon Availability Until 2100, SPE 68755 presented at the SPE Asia Pacific Oil and GasConference, Jakarta, Indonesia, April 17-19, 2001.

Mian, M.A., 2002. Project Economics and Decline Analysis Volume I: Deterministic Models, Tulsa, Oklahoma, Penwell Books.

Navigant Consulting, 2008. North American Natural Gas Supply Assessment. Navigant Consulting, Houston, TX.

Old, S., 2008. Technology and Economics Affecting Unconventional Reservoir Development, MS Thesis, Texas A\&M University, College Station, TX.

Rogner, H., 1997. An Assessment of World Hydrocarbon Resources, Institute for Integrated Energy System, An Assessment of World Hydrocarbon Resources, Annual Review of Energy Environment, 22:217-262.

Securities and Exchange Commission, 2010. Modernization of Oil and Gas Reporting (SEC Release No. 33-8995, pp. 11-12).

Singh, K. 2006. Basin Analog Approach Answers Characterization Challenges of Unconventional Gas Potential in Frontier Basins, MS Thesis, Texas A\&M University, College Station, TX.

Texas Railroad Commission, 2010. Barnett Shale Information http://www.rrc.state.tx.us/barnettshale/index.php.

US Department of Energy (DOE), 2009. Modern Shale Gas Development in the United States: A Primer. US DOE, Washington, DC. 
USGS Southwestern Wyoming Province Assessment Team, 2005, Petroleum Systems and Geologic Assessment of Oil and Gas in the Southwestern Wyoming Province, Wyoming, Colorado, and Utah, Denver: Geological Survey, Information Services. 


\section{APPENDIX A}

Application input screen:

\section{ECONOMIC EVALUATION OF BARNETT SHALE}

User Specified Reserves, 10, 50 \& 90\%-tile

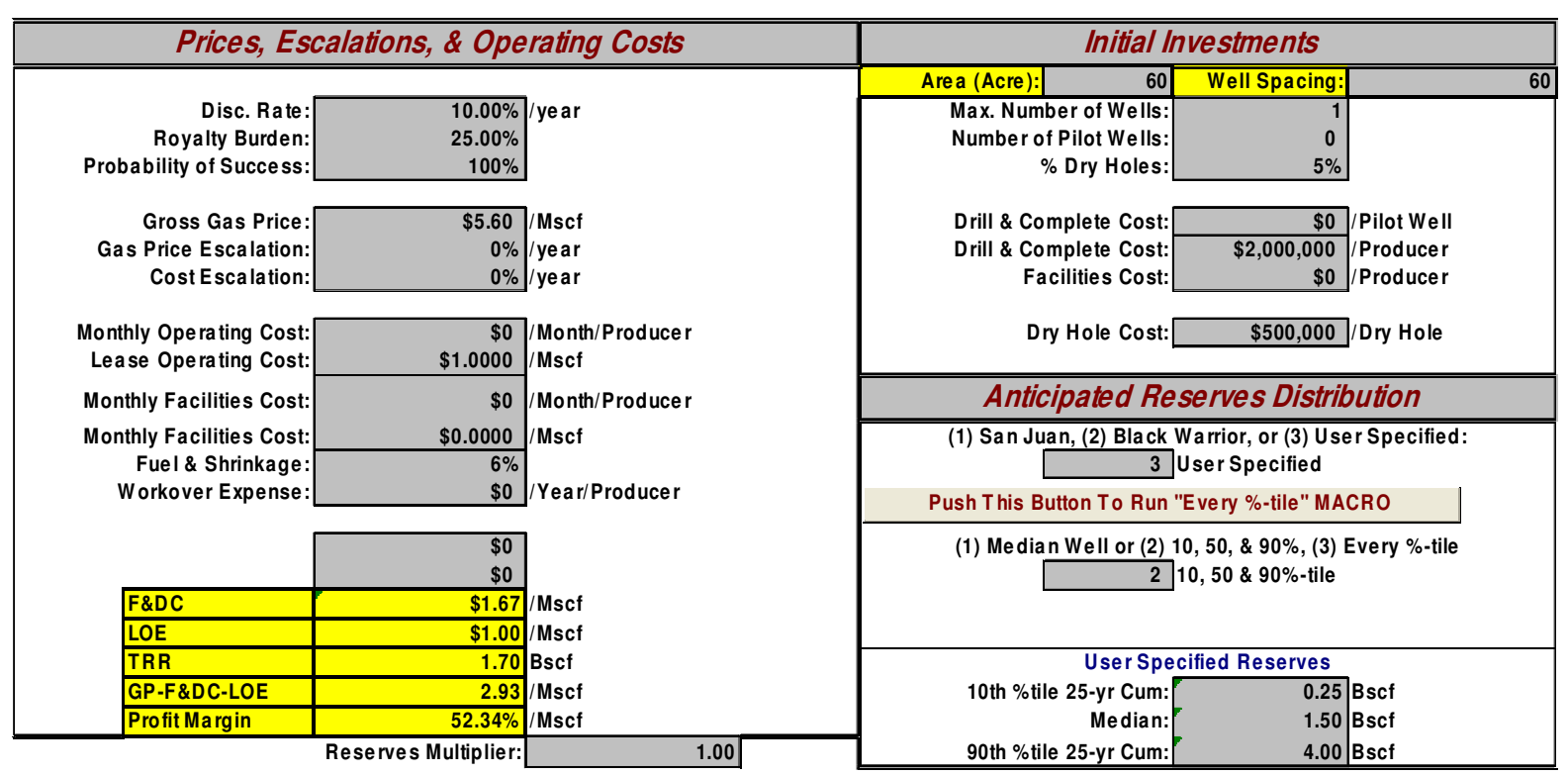

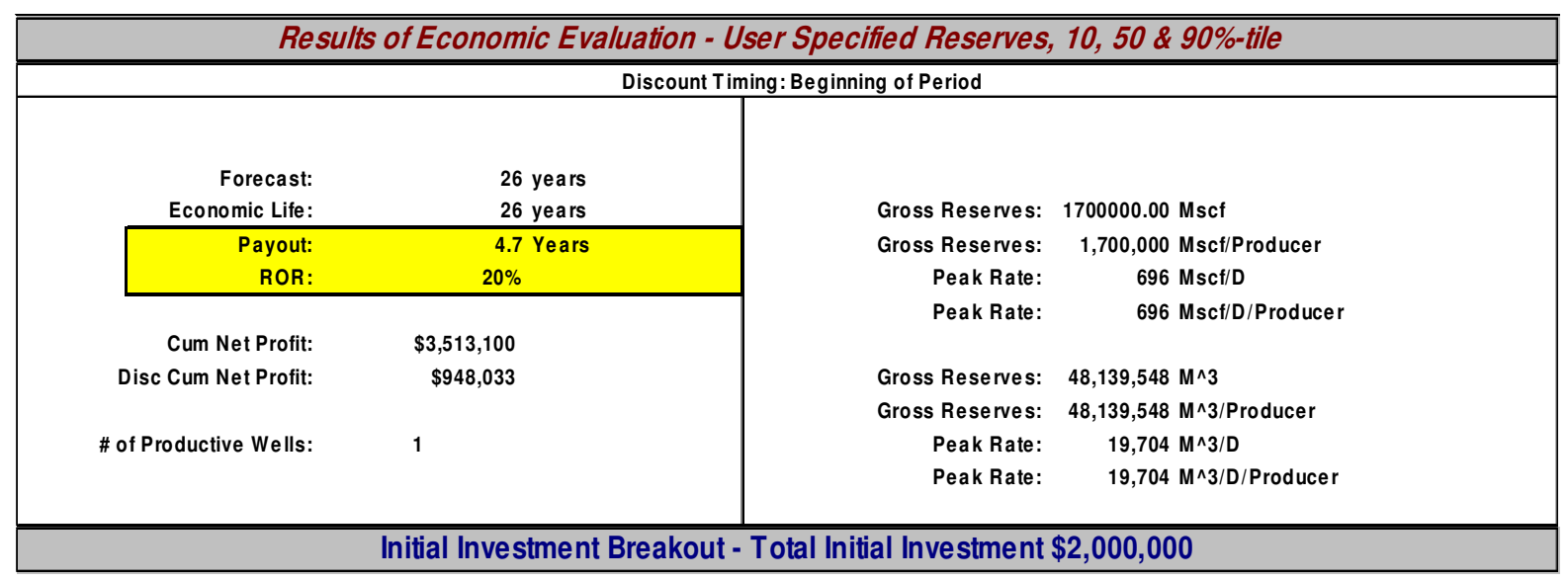




\section{APPENDIX B}

Assumptions for Detailed Economic Analysis:

Scenario I Assumptions:

○ 25-Year well life

○ F\&DC @ \$2 million

○ $0 \%$ royalty burden

- $100 \%$ probability of success

○ $0 \%$ escalation of gas prices and costs

○ $0 \%$ fuel and shrinkage

○ LOE @ \$1.0/Mcf

- $10 \%$ annual discount rate

Scenario II Assumptions:

○ 25-Year well life

○ F\&DC @ \$2 million

○ $25 \%$ royalty burden

- $90 \%$ probability of success

$\circ 0 \%$ escalation of gas prices and costs

- $6 \%$ fuel and shrinkage

○ LOE @ \$1.0/Mcf

○ $10 \%$ annual discount rate 


\section{APPENDIX C}

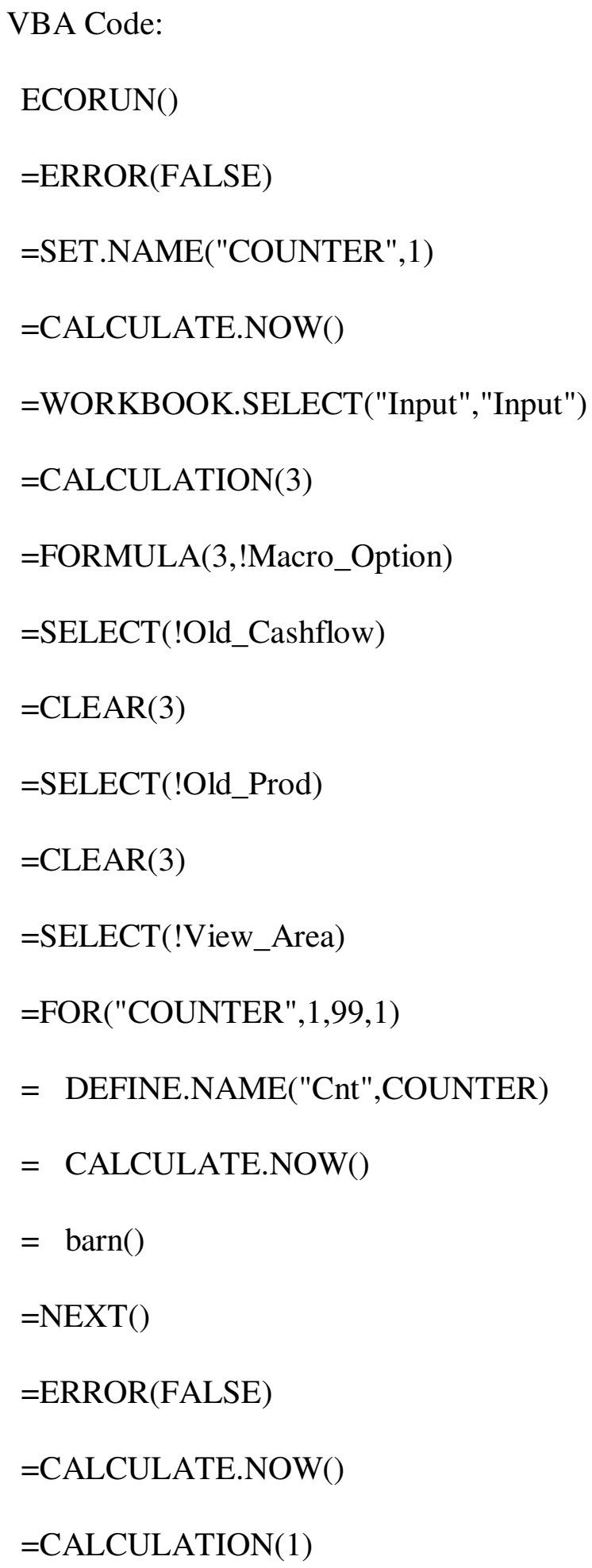




$$
\begin{aligned}
& =\text { SELECT }(\text { !\$A1) } \\
& =\text { ERROR(TRUE) } \\
& =\text { ECHO(TRUE) } \\
& =\text { RETURN }()
\end{aligned}
$$

SUB1()

$=$ FORMULA(!New_MACRO_EUR,!MACRO_EUR)

=CALCULATE.NOW()

$=$ SELECT $(!$ New_Cashflow $)$

$=\mathrm{COPY}()$

$=$ SELECT $($ !Old_Cashflow $)$

$=$ PASTE.SPECIAL(3,1,FALSE,FALSE)

$=$ CANCEL.COPY ()

$=$ SELECT $(!$ New_Prod $)$

$=\mathrm{COPY}()$

$=$ SELECT $($ !Old_Prod $)$

$=$ PASTE.SPECIAL(3,1,FALSE,FALSE)

$=$ CANCEL.COPY ()

$=\mathrm{RETURN}()$

SENS()

=SET.NAME("PARAMCNT",1)

=SET.NAME("SENSCNT",1)

=WORKBOOK.SELECT("Input","Input") 


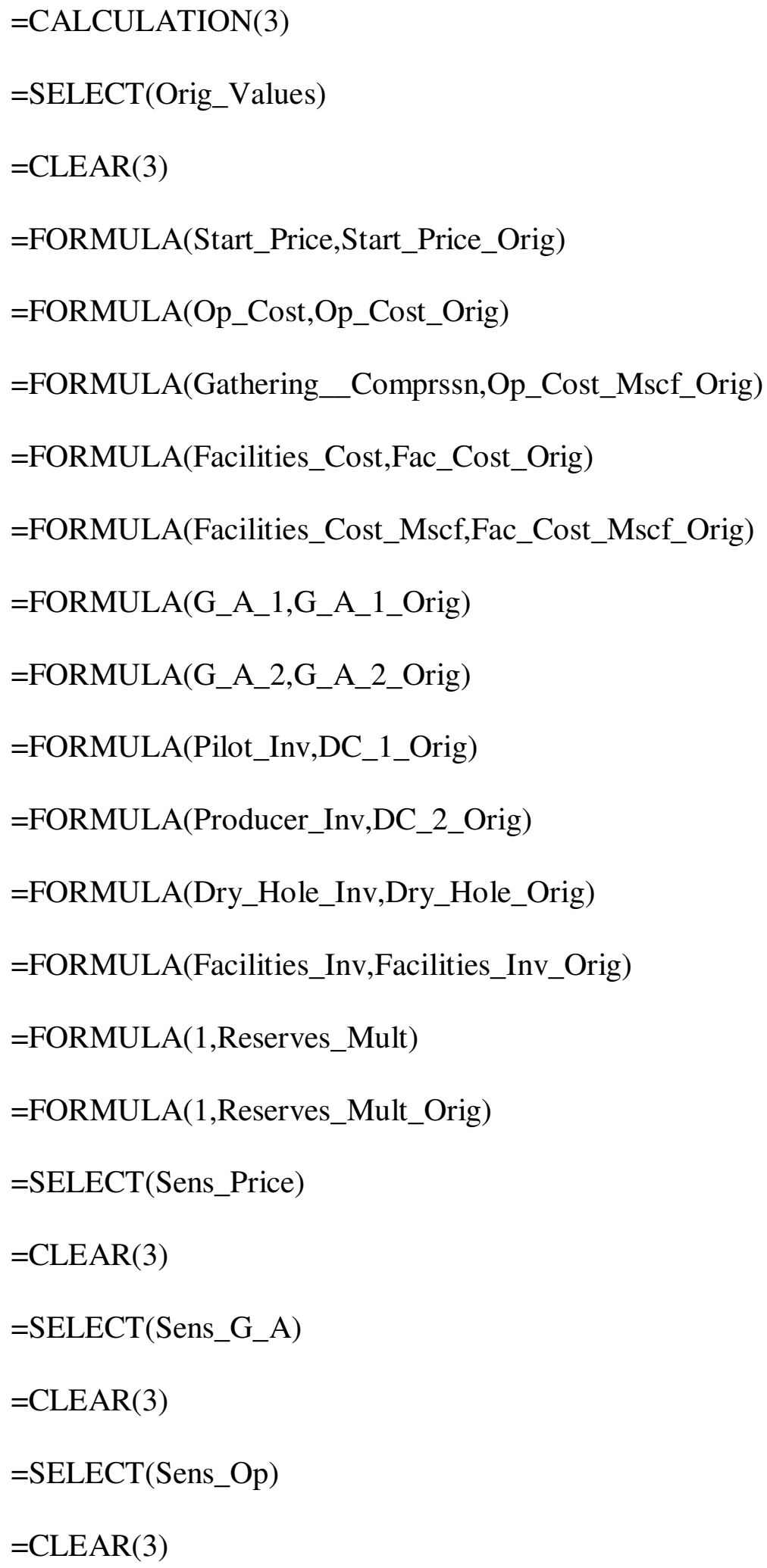




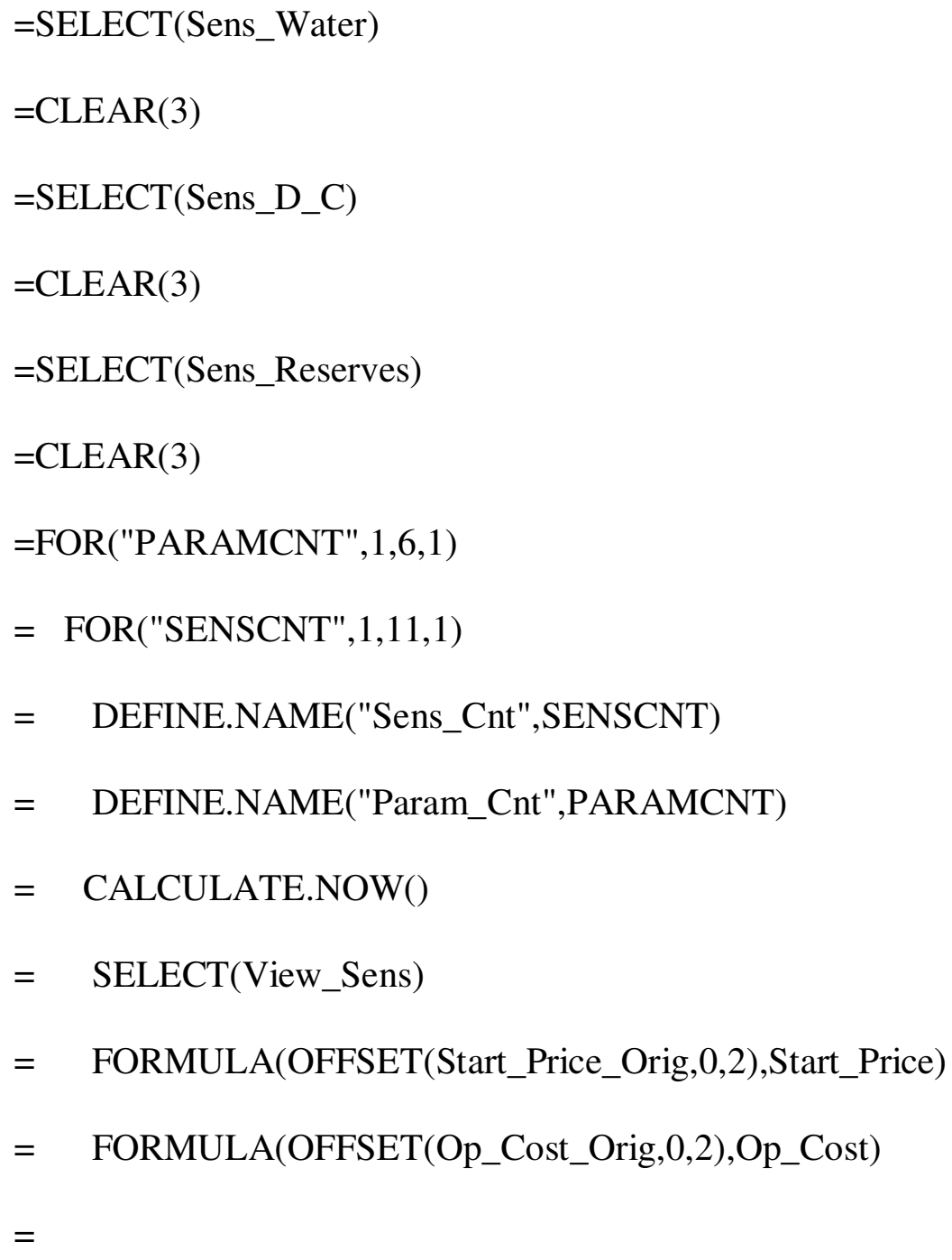


$=$ FORMULA(OFFSET(DC_2_Orig,0,2),Producer_Inv)

$=$ FORMULA(OFFSET(Dry_Hole_Orig,0,2),Dry_Hole_Inv)

$=$ FORMULA $($ OFFSET(Facilities_Inv_Orig,0,2),Facilities_Inv)

$=$ FORMULA(OFFSET(Reserves_Mult_Orig,0,2),Reserves_Mult $)$

$=$ CALCULATE.NOW ()

$=\quad \mathrm{IF}($ Macro_Option=3,ecorun( $))$

$=$ FORMULA(ROR_Final,OFFSET(Sens_Corner,SENSCNT-

$1,1+($ PARAMCNT-1)*3))

$=\operatorname{NEXT}()$

$=\operatorname{NEXT}()$

=FORMULA(Start_Price_Orig,Start_Price)

=FORMULA(Op_Cost_Orig,Op_Cost $)$

=FORMULA(Op_Cost_Mscf_Orig,Gathering_CComprssn)

=FORMULA(Fac_Cost_Orig,Facilities_Cost)

=FORMULA(Fac_Cost_Mscf_Orig,Facilities_Cost_Mscf)

$=$ FORMULA(G_A_1_Orig,G_A_1)

=FORMULA(G_A_2_Orig,G_A_2)

=FORMULA(DC_1_Orig,Pilot_Inv)

=FORMULA(DC_2_Orig,Producer_Inv)

=FORMULA(Dry_Hole_Orig,Dry_Hole_Inv)

=FORMULA(Facilities_Inv_Orig,Facilities_Inv)

$=$ FORMULA $(1$, Reserves_Mult $)$ 


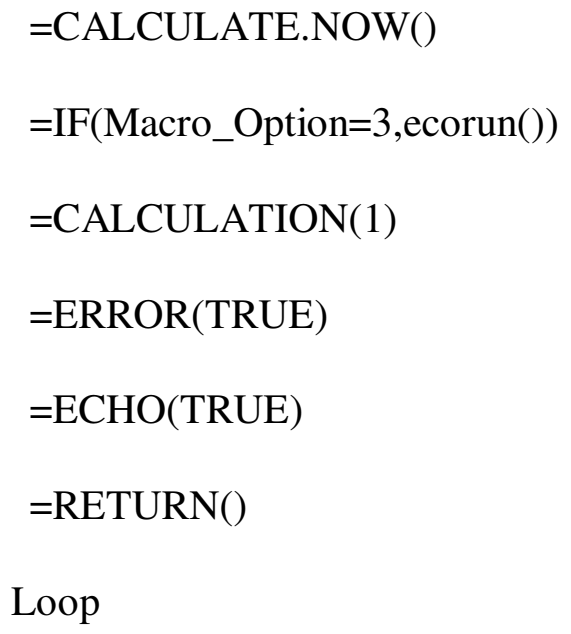

End With

ErrHandler:

Resume Next

End Sub

Sub GPRUNALL905010()

Dim ROR As Double

Dim PayOut As Double

Dim GP As Double

Dim LOE As Double

Dim FDCMSCF As Double

Dim EUR As Double

Dim FDC As Double

Dim increment As Double

On Error GoToErrHandler:

With ThisWorkbook.Worksheets("Input") 


$$
\begin{aligned}
& \text { Cells }(22,7)=2 \\
& \text { increment }=0 \\
& \text { FDC }=250000 \\
& \text { Do Until FDC }>4000000 \\
& \text { GP }=0 \\
& \text { ROR }=0 \\
& . \text { Cells }(11,8)=\text { FDC } \\
& \text { Cells }(10,3)=\text { GP } \\
& \text { ROR }=. \text { Cells }(37,3) * 100 \\
& \text { PayOut }=. \text { Cells }(36,3) . \text { Value }
\end{aligned}
$$

Do Until ROR >= 20 And PayOut $<5$

$$
\mathrm{GP}=\mathrm{GP}+0.1
$$

$$
\begin{aligned}
& \text { Cells }(10,3)=\mathrm{GP} \\
& \text { ROR }=. \text { Cells }(37,3) . \text { Value } * 100 \\
& \text { PayOut }=. \text { Cells }(36,3) \text {.Value } \\
& \text { Loop } \\
& \text { LOE }=. \text { Cells }(24,3) \\
& \text { FDCMSCF }=. \text { Cells }(23,3) \\
& \text { EUR }=. \text { Cells }(35,7) / 1000000 \\
& \text { Cells }(34+\text { increment }, 22)=\text { GP }- \text { LOE }- \text { FDCMSCF } \\
& \text { Cells }(34+\text { increment, } 21)=\text { GP } \\
& \text { increment }=\text { increment }+1
\end{aligned}
$$


$F D C=F D C+250000$

Loop

End With

ErrHandler:

Resume Next

End Sub 
VITA

Name:

Husameddin Saleh A. AlMadani

Born:

Edinburgh, Scotland

Permanent Address:

P.O. Box 6281

Saudi Aramco

Dhahran, Saudi Arabia 31311

Email:

husam.madani@gmail.com

Education:

M.S., Petroleum Engineering,

Texas A\&M University

College Station, TX, 2010

United States

B. S., Computer Science, University of Kansas

Lawrence, KS, 2003

United States

Member:

International Association for Energy

Economics (IAEE).

Society of Petroleum Engineers (SPE). 